\title{
ESTUDO DA EXPANSÃO DO SETOR ELÉTRICO BRASILEIRO COM GERAÇÃO TERMELÉTRICA À GÁS NATURAL
}

ANDERSON LUIZ MONTEIRO CAVALCANTE

LEONARDO DUARTE SILVA

TRABALHO DE CONCLUSÃO DO CURSO DE ENGENHARIA ELÉTRICA

DEPARTAMENTO DE ENGENHARIA ELÉTRICA

\section{FACULDADE DE TECNOLOGIA}




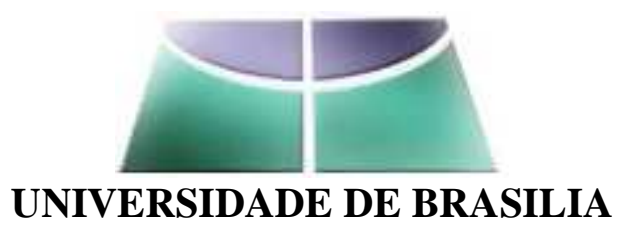

Faculdade de Tecnologia

\title{
TRABALHO DE GRADUAÇÃO \\ ESTUDO DA EXPANSÃO DO SETOR ELÉTRICO \\ BRASILEIRO COM GERAÇÃO TERMELÉTRICA À GAS NATURAL
}

\author{
Anderson Luiz Monteiro Cavalcante 04/12236 \\ Leonardo Duarte Silva $\quad 04 / 33501$ \\ Relatório submetido como requisito parcial para obtenção \\ do grau de Engenheiro Eletricista
}

Brasília, 4 de dezembro de 2008.

Banca Examinadora

Prof. Ivan Marques de Toledo Camargo, UnB/ENE(Orientador)

Prof. Francisco Damasceno Freitas, UnB/ENE

Prof. Rafael Amaral Shayani UnB/ ENE 


\section{AGRADECIMENTOS}

A todos que nos apoiaram e a nossas famílias. 


\section{RESUMO}

O presente trabalho de conclusão de curso faz uma abordagem sistêmica dos aspectos econômicos e técnicos da expansão da energia elétrica no país, dentro dos empreendimentos hídricos e térmicos, observando fontes energéticas no processo e, principalmente, o gás natural. O gás natural é um combustível que norteia o desenvolvimento da matriz energética brasileira, sendo imprescindível sua estruturação dentro de um mercado regulatório claro e conciso que forneça as bases para a sua cadeia de valor. Ele representa o paradigma do futuro, devido à sua eficiência energética e seu baixo impacto ambiental relacionado a outros insumos, como carvão mineral, óleo diesel e combustível. Sua ambientação no panorama energético brasileiro alicerça a diversificação da geração energética nacional. Será avaliado dentro da ótica de sua atratividade econômica no setor energético. Para tanto, após uma breve contextualização do setor elétrico brasileiro, será feita uma análise dos leilões de Energia Nova quanto a aspectos institucionais, agentes e seus resultados ao longo dos 7 primeiros leilões ocorridos até a data deste trabalho. Posteriormente, será analisado o estudo da expansão do setor elétrico com foco nessa fonte de geração de energia, dentre diversas outras, observando os cenários mundial e nacional, a cadeia de valor e os fundamentos econômicos do gás natural. Em seguida serão apresentados os custos que estão envolvidos na composição de uma usina termelétrica evidenciando a metodologia de cálculo do ICB que é um parâmetro indicador da viabilidade do empreendimento térmico. Finalmente, será feito um estudo de caso a fim de mostrarmos na prática os tópicos abordados neste trabalho. 


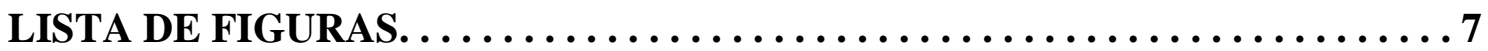

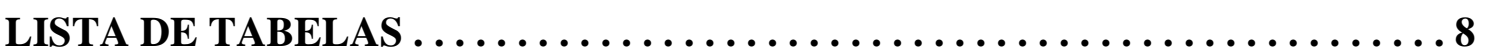

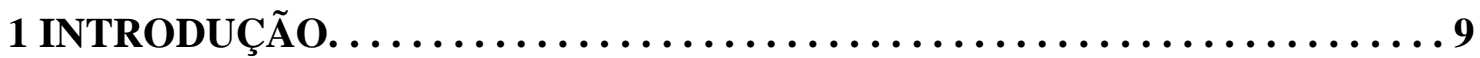

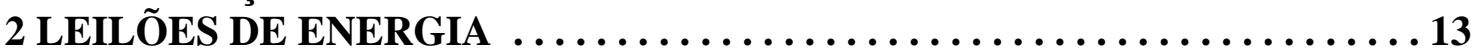

2.1 Aspectos Institucionais. . . . . . . . . . . . . . . . . . . . . . 13

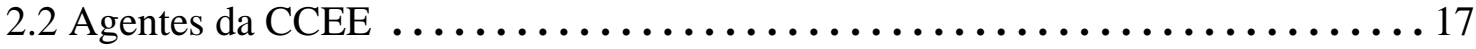

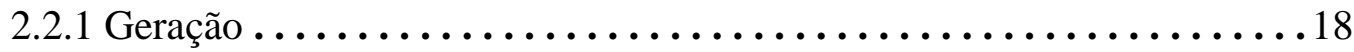

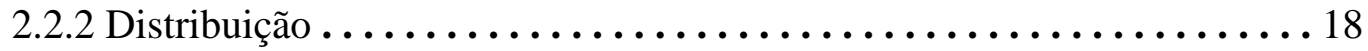

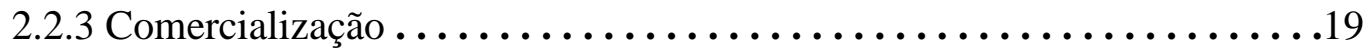

2.3 Classificação dos Leilões. . . . . . . . . . . . . . . . . . . . . . 19

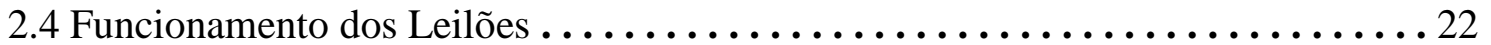

2.5 Análise dos Leilões de Energia Nova ..............................

2.5 .1 Primeiro Leilão de Energia Nova ......................... 24

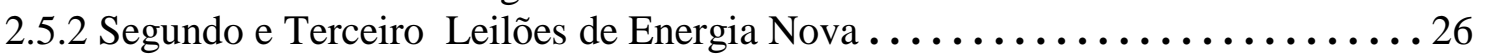

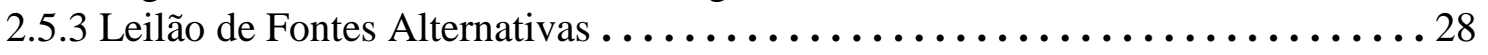

2.5.4 Quarto e Quinto Leilões de Energia Nova ..................... 30

2.5.5 Sexto e Sétimo Leilões de Energia Nova . . . . . . . . . . . . . . . 32

2.5.6 Apreciação Global dos Leilões de Energia .................. 33

2.6 Gás Natural nos Leilões de Energia Nova. . . . . . . . . . . . . . . . . . . 37

2.6.1 Energia Térmica e o Gás Natural nos Submercados ............. 42

3 ANÁlISE DA EXPANSÃO ENERGÉTICA POR MEIO DO USO DO GÁS

NATURAL ................................... 44

3.1 Matrizes Energéticas. .................................. 44

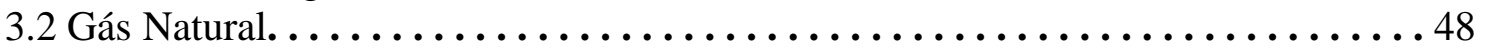

3.2.1 Gás Natural no Mundo .......................... 50

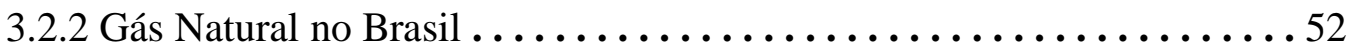

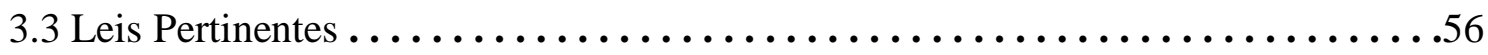

3.4 Cadeia de Valor do Gás Natural. . . . . . . . . . . . . . . . . . . 57

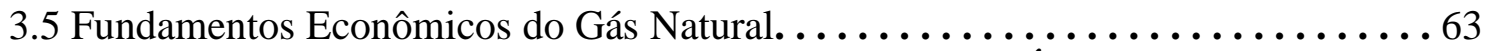

4 ESTRUTURA DE CUSTOS DE USINAS TERMELELÉTRICAS. . . . . . . . 66

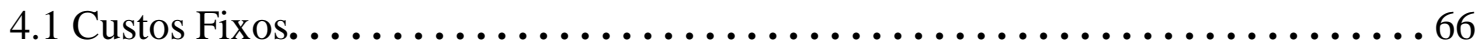

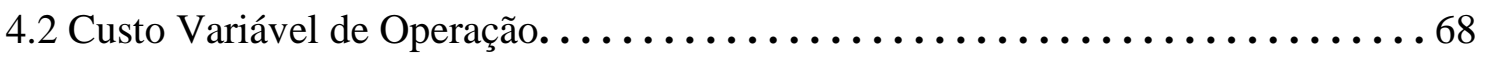

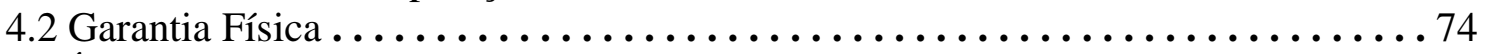

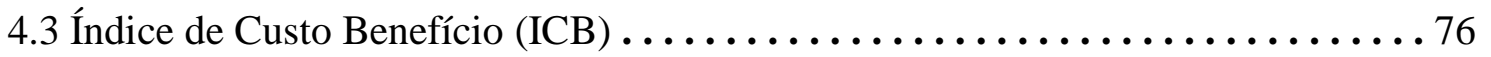

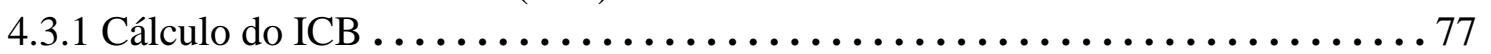

5 ESTUDO DE CASO $\ldots \ldots \ldots \ldots \ldots \ldots \ldots \ldots \ldots \ldots \ldots \ldots \ldots \ldots \ldots \ldots \ldots \ldots \ldots$

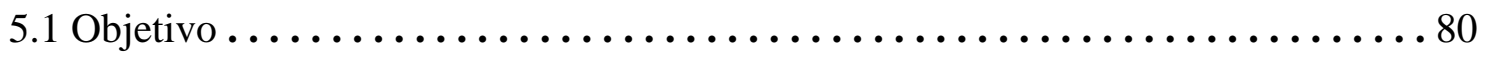

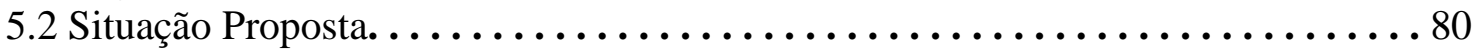

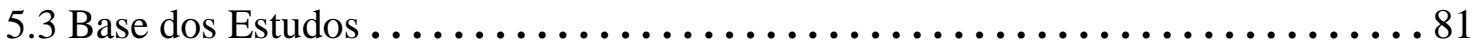

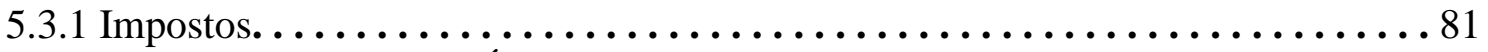

5.3.2 Dados para Geração a Óleo PTE na Termonorte II ............... 81

5.3.3 Dados para Geração a Gás Natural na Termonorte II .............. 82

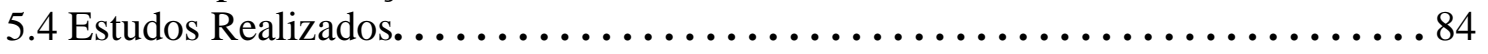

5.4.1 Cálculo da Garantia Física para Termonorte II. . . . . . . . . . . . . 85

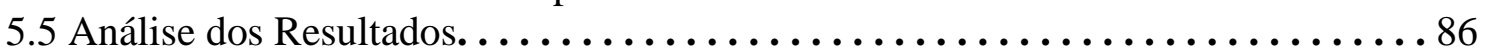

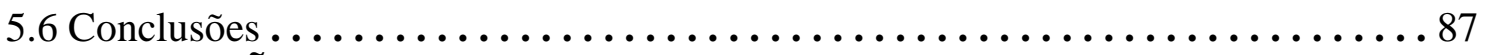

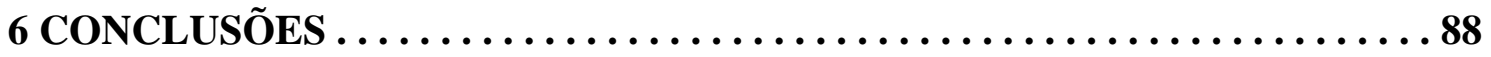


7 REFERÊNCIAS BIBLIOGRÁFICAS ..........................90 


\section{LISTA DE FIGURAS}

Fig. 2.1 - Diagrama das instituições do setor elétrico brasileiro. . . . . . . . . . . . . . . 13

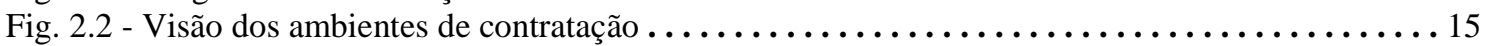

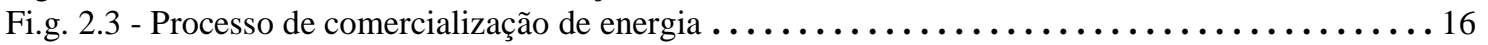

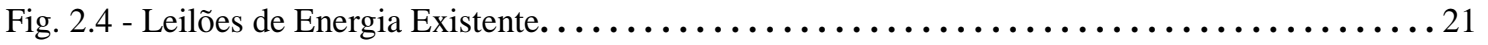

Fig. 2.5 - Rodadas Uniformes . . . . . . . . . . . . . . . . . . . . . . . . . . . 23

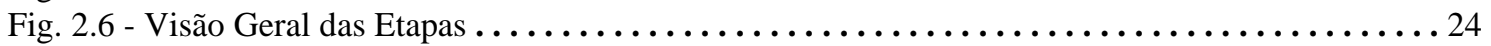

Fig. 2.7 - Quantidade de lotes comercializados no $1^{\circ}$ Leilão de Energia de Compra de Energia Nova. .. 25

Fig. 2.8 - Quantidade de lotes comercializados no $2^{\circ}$ Leilão de Energia de Compra de Energia Nova. . . 27

Fig. 2.9 - Quantidade de lotes comercializados no $3^{\circ}$ Leilão de Energia de Compra de Energia Nova. .. 28

Fig. 2.10 - Comparação da potência relacionada no Leilão de Energia Alternativa. . . . . . . . . . . . . . 29

Fig. 2.11 - Quantidade de lotes comercializados no $4^{\circ}$ Leilão de Energia de Compra de Energia Nova. . 31 Fig. 2.12 - Quantidade de lotes comercializados no $5^{\circ}$ Leilão de Energia de Compra de Energia Nova. . 32 Fig. 2.13 - Quantidade de lotes comercializados no $6^{\circ}$ Leilão de Energia de Compra de Energia Nova. . 33 Fig. 2.14 - Quantidade de lotes comercializados no $7^{\circ}$ Leilão de Energia de Compra de Energia Nova. .33

Fig. 2.15 - Energia Contratada em MW médios ao longo dos Leilões. . . . . . . . . . . . . . . . . . . 34

Fig. 2.16 - Evolução da Energia Contratada em MW médio ao longo dos Leilões. . . . . . . . . . . . . 34

Fig. 2.17 - Expansão do Setor Elétrico em termos térmicos e hídricos para os cinco primeiros leilões .. 35

Fig. 2.18 - Preço da Energia Térmica nos leilões $(\mathrm{ICB}-\mathrm{R} \$ / \mathrm{MWh}) \ldots \ldots \ldots \ldots \ldots \ldots \ldots \ldots \ldots \ldots \ldots$

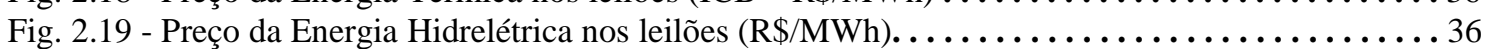

Fig. 2.20 - Resultado do Tipo de Combustível do $1 .^{\circ}$ e $2 .^{\circ}$ Leilões de Energia Nova . . . . . . . . . . 38

Fig. 2.21 - Resultado do Tipo de Combustível do $3 .^{\circ}$ e $4 .^{\circ}$ Leilões de Energia Nova . . . . . . . . . . 39

Fig. 2.22 - Resultado do Tipo de Combustível do $5 .^{\circ}$ e $6 .^{\circ}$ Leilões de Energia Nova ... . . . . . . . 40

Fig. 2.23 - Resultado do Tipo de Combustível do $7^{\circ}$ Leilão de Energia Nova. . . . . . . . . . . . . 40

Fig. 2.24 - Gás Natural nos Leilões de Energia Nova ......................... 41

Fig. 2.25 - Gás Natural ao longo dos Anos de Expansão. . . . . . . . . . . . . . . . . . 41

Fig. 2.26 - Participação térmica em MW médios quanto aos submercados. . . . . . . . . . . . . . . 42

Fig. 3.1 - Preços internacionais do Petróleo, Gás Natural e Carvão. . . . . . . . . . . . . . . . . 45

Fig. 3.2 - Volume total importado de gás natural (mil $\mathrm{m} 3$ por dia) $\ldots \ldots \ldots \ldots \ldots \ldots \ldots \ldots \ldots \ldots$

Fig. 3.3 - Reservas provadas de gás natural no Brasil . . . . . . . . . . . . . . . . . . . . . 52

Fig. 3.4 - Distribuição percentual das reservas provadas de gás natural, por Unidades da Federação. . . 54

Fig. 3.5 - Produção de Gás Natural em 2007 e participação por estado. . . . . . . . . . . . . . . . . . 55

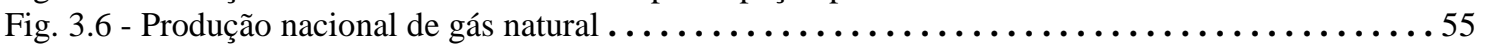

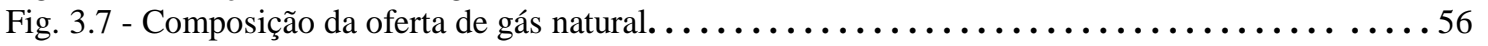

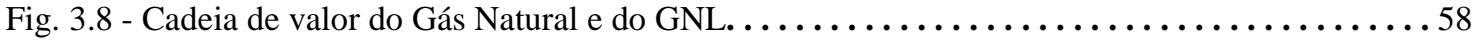

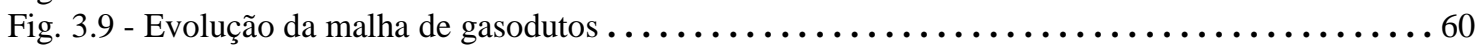

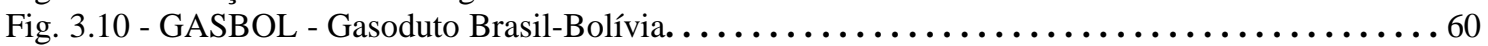

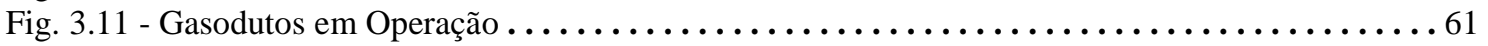

Fig. 3.12 - 'Gasoduto Virtual' ...................................... 63

Fig. 4.1 - Comparação de preço para cada combustível pela sua energia gerada com base em 2007 e nos

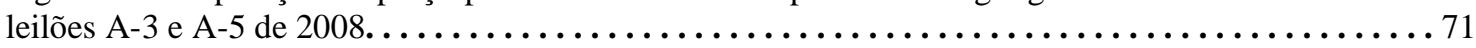

Fig. 4.2 - Comparação do Custo de Combustível no em início em 2008 . . . . . . . . . . . . . . 73

Fig. 5.1 - Curva Característica para Cálculo da Garantia Física. . . . . . . . . . . . . . . . . . 84 


\section{LISTA DE TABELAS}

Tabela 1.1 - Resumo de Comparação dos modelos do setor elétrico brasileiro. .............. 11

Tabela 2.1 - Primeiro Leilão 16.12.2005 (MW Médio . . . . . . . . . . . . . . . . . . . . . . 25

Tabela 2.2 - Segundo Leilão (A-3) - 29.6.2006 e Terceiro Leilão (A-5)-10.10.2006 (MW Médios) . . . .27

Tabela 2.3 - Empreendimentos Habilitados FA. . . . . . . . . . . . . . . . . . . . . . . . . . 29

Tabela 2.4 - Quarto Leilão (A-3) - 26.7.2007 e Quinto Leilão (A-5)-16.10.2007 (MW Médios) . . . . . 31

Tabela 2.5 - Sexto Leilão (A-3) - 17.9.2008 e Sétimo Leilão (A-5) - 30.9.2008 (MW Médios) . . . . . .32

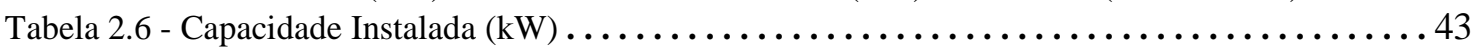

Tabela 3.1 - Composição do Gás Natural no Espírito Santo. . . . . . . . . . . . . . . . . . . 49

Tabela 3.2 - Reservas de Gás Natural no Brasil. . . . . . . . . . . . . . . . . . . . . . .53

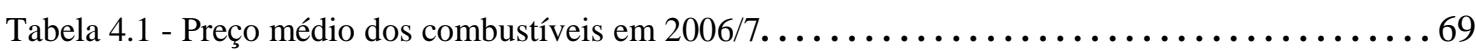

Tabela 4.2 - Preço médio dos combustíveis em 2008 (Leilão A-3) . . . . . . . . . . . . . . . . . .70

Tabela 4.3 - Preço médio dos combustíveis em 2008 (Leilão A-5) . . . . . . . . . . . . . . . . . . 70

Tabela 4.4 - Empreendimentos e Custos de Combustíveis para início em 2008. . . . . . . . . . . . 72

Tabela 4.5 - Proporcionalidade da Carga. . . . . . . . . . . . . . . . . . . . . . 75

Tabela 5.1 - Dados para caracterização da Garantia Física. ... . . . . . . . . . . . . 85

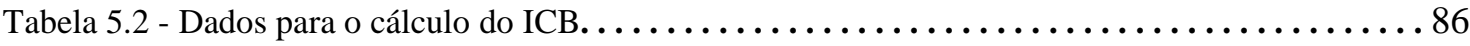




\section{INTRODUÇÃO}

O comportamento da carga energética acompanha os efeitos do desempenho da economia no consumo de energia elétrica. A performance do mercado de energia ao longo dos últimos anos refletiu os bons indicadores que a economia brasileira vem apresentando; cabe ressaltar o comportamento favorável daqueles que impulsionam a demanda interna, como o aumento da renda, a queda dos juros e a maior disponibilidade e alongamento do crédito.

Com o aumento da demanda da energia elétrica pelo crescimento do país, intensifica-se o estudo da diversificação da matriz energética, buscando um aproveitamento dos recursos brasileiros e de novas tecnologias. Nessa ótica, avaliar o futuro da geração energética é observar características econômicas e tecnológicas e, claramente, retratar todos os aspectos envolvidos em escolhas que visam minimizar impactos ambientais. Desse modo, o setor elétrico brasileiro, na busca por essa evolução, passou por várias mudanças até ao atual modelo.

A reforma do Setor Elétrico Brasileiro começou em 1993 com a Lei $n^{\circ}$ 8.631, que extinguiu a equalização tarifária vigente e criou os contratos de suprimento entre geradores e distribuidores, e foi marcada pela promulgação da Lei nº 9.074 de 1995, que criou o Produtor Independente de Energia e o conceito de Consumidor Livre.

Em 1996 foi implantado o Projeto de Reestruturação do Setor Elétrico Brasileiro (Projeto RE-SEB), coordenado pelo Ministério de Minas e Energia.

As principais conclusões do projeto foram a necessidade de implementar a desverticalização das empresas de energia elétrica, ou seja, dividi-las nos segmentos de geração, transmissão e distribuição, incentivar a competição nos segmentos de geração e comercialização, e manter sob regulação os setores de distribuição e transmissão de energia elétrica, considerados como monopólios naturais, sob regulação do Estado.

Foi também identificada a necessidade de criação de um órgão regulador (a Agência Nacional de Energia Elétrica - ANEEL), de um operador para o sistema elétrico nacional (Operador Nacional do Sistema Elétrico - ONS) e de um ambiente para a realização das transações de compra e venda de energia elétrica (o Mercado Atacadista de Energia Elétrica MAE). 
Concluído em agosto de 1998, o Projeto RE-SEB definiu o arcabouço conceitual e institucional do modelo a ser implantado no Setor Elétrico Brasileiro.

Em 2001, o setor elétrico sofreu uma grave crise de abastecimento que culminou em um plano de racionamento de energia elétrica. Esse acontecimento gerou uma série de questionamentos sobre os rumos que o setor elétrico estava trilhando. Visando adequar o modelo em implantação, foi instituído em 2002 o Comitê de Revitalização do Modelo do Setor Elétrico, cujo trabalho resultou em um conjunto de propostas de alterações no setor elétrico brasileiro.

Uma das alternativas utilizadas durante essa crise foi a aceleração da inserção de Usinas Termelétricas, já que esse incentivo tinha se iniciado em fevereiro de 2000 com o projeto criado pelo governo: Programa Prioritário de Termeletricidade - PPT. O objetivo do programa era criar condições de atendimento de curto prazo e permitir ganhos de confiabilidade e eficiência no sistema de energia elétrica, segundo o aproveitamento racional das fontes de energia principalmente com a utilização do gás natural - Portaria MME №43, de 25 de fevereiro de 2000. Assim, seria reduzida a dependência em relação às hidrelétricas e minimizada a hipótese de apagões e racionamento de energia.

Durante os anos de 2003 e 2004 o Governo Federal lançou as bases de um novo modelo para o Setor Elétrico Brasileiro, sustentado pelas Leis $\mathrm{n}^{\circ} 10.847$ e 10.848 , de 15 de março de 2004 e pelo Decreto n ${ }^{\circ}$ 5.163, de 30 de julho de 2004.

Veja a seguir na tabela 1.1 um resumo das principais mudanças entre os modelos préexistentes e o modelo atual, que acabaram por resultar em transformações nas atividades de alguns agentes do setor.

Analisando as mudanças acerca da reestruturação do setor elétrico brasileiro percebe-se que ele deixou de possuir um caráter predominantemente estatal monopolista para tornar-se mais competitivo na medida em que possibilitou a inserção de empresas privadas. Vê-se que outro aspecto importante foi a desverticalização das empresas fazendo que com que as essas atuassem em atividades específicas. Ainda assim, por representar um serviço de utilidade pública, a atuação do Estado quanto à regulação e fiscalização do setor elétrico teve acertadamente de evoluir ao longo do tempo de modo que houvesse a criação de regras importantes e o planejamento de ações futuras. Tudo isso, por meio da criação de órgãos e entidades públicos, favorece o funcionamento do setor elétrico brasileiro que agora tem uma forma mais dinâmica com base no mercado. A dinamicidade vem dos investimentos associados aos possíveis riscos tanto do setor elétrico quanto do setor energético. 
Tabela 1.1 - Resumo de Comparação dos modelos do setor elétrico brasileiro

\begin{tabular}{|c|c|c|}
\hline Modelo Antigo (até 1995) & $\begin{array}{c}\text { Modelo de Livre } \\
\text { Mercado (1995 a 2003) }\end{array}$ & Novo Modelo (2004) \\
\hline $\begin{array}{l}\text { Financiamento através de } \\
\text { recursos públicos }\end{array}$ & $\begin{array}{c}\text { Financiamento através de } \\
\text { recursos públicos e } \\
\text { privados }\end{array}$ & $\begin{array}{c}\text { Financiamento através de recursos } \\
\text { públicos e privados }\end{array}$ \\
\hline Empresas verticalizadas & $\begin{array}{l}\text { Empresas divididas por } \\
\text { atividade: geração, } \\
\text { transmissão, distribuição } \\
\text { e comercialização }\end{array}$ & $\begin{array}{l}\text { Empresas divididas por atividade: } \\
\text { geração, transmissão, distribuição, } \\
\text { comercialização, importação e } \\
\text { exportação. }\end{array}$ \\
\hline $\begin{array}{c}\text { Empresas predominantemente } \\
\text { Estatais }\end{array}$ & \begin{tabular}{|c|} 
Abertura e ênfase na \\
privatização das Empresas
\end{tabular} & $\begin{array}{c}\text { Convivência entre Empresas } \\
\text { Estatais e Privadas }\end{array}$ \\
\hline $\begin{array}{l}\text { Monopólios - Competição } \\
\text { inexistente }\end{array}$ & $\begin{array}{c}\text { Competição na geração e } \\
\text { comercialização }\end{array}$ & $\begin{array}{l}\text { Competição na geração e } \\
\text { comercialização }\end{array}$ \\
\hline Consumidores Cativos & $\begin{array}{l}\text { Consumidores Livres e } \\
\text { Cativos }\end{array}$ & Consumidores Livres e Cativos \\
\hline $\begin{array}{l}\text { Tarifas reguladas em todos os } \\
\text { segmentos }\end{array}$ & $\begin{array}{c}\text { Preços livremente } \\
\text { negociados na geração e } \\
\text { comercialização }\end{array}$ & $\begin{array}{c}\text { No ambiente livre: Preços } \\
\text { livremente negociados na geração } \\
\text { e comercialização. No ambiente } \\
\text { regulado: leilão e licitação pela } \\
\text { menor tarifa }\end{array}$ \\
\hline Mercado Regulado & Mercado Livre & $\begin{array}{c}\text { Convivência entre Mercados Livre } \\
\text { e Regulado }\end{array}$ \\
\hline $\begin{array}{c}\text { Planejamento Determinativo - } \\
\text { Grupo Coordenador do } \\
\text { Planejamento dos Sistemas } \\
\text { Elétricos (GCPS) }\end{array}$ & $\begin{array}{l}\text { Planejamento Indicativo } \\
\text { pelo Conselho Nacional } \\
\text { de Política Energética } \\
\text { (CNPE) }\end{array}$ & $\begin{array}{l}\text { Planejamento pela Empresa de } \\
\text { Pesquisa Energética (EPE) }\end{array}$ \\
\hline $\begin{array}{c}\text { Contratação: } 100 \% \text { do } \\
\text { Mercado }\end{array}$ & $\begin{array}{c}\text { Contratação: } 85 \% \text { do } \\
\text { mercado (até } \\
\text { agosto/2003) e } 95 \% \\
\text { mercado (até dez./2004) }\end{array}$ & $\begin{array}{c}\text { Contratação: } 100 \% \text { do mercado + } \\
\text { reserva }\end{array}$ \\
\hline $\begin{array}{l}\text { Sobras/déficits do balanço } \\
\text { energético rateados entre } \\
\text { compradores }\end{array}$ & $\begin{array}{c}\text { Sobras/déficits do balanço } \\
\text { energético liquidados no } \\
\text { MAE }\end{array}$ & $\begin{array}{c}\text { Sobras/déficits do balanço } \\
\text { energético liquidados na CCEE. } \\
\text { Mecanismo de Compensação de } \\
\text { Sobras e Déficits (MCSD) para as } \\
\text { Distribuidoras. }\end{array}$ \\
\hline
\end{tabular}

Fonte: CCEE

Em um sistema predominantemente hidráulico - como é o caso do Brasil -, é possível e economicamente justificável subordinar a utilização das termelétricas ao regime hidrológico. Esse regime determina a maior ou menor disponibilidade de energia gerada pelas usinas hidrelétricas. Assim, em períodos de hidrologia favorável, as térmicas tendem a ser despachadas no mínimo, ou mesmo desligadas, aproveitando-se o excedente de geração hidrelétrica. Ao contrário, em situações de hidrologia desfavorável, a geração térmica tende a garantir o 
atendimento da carga, gerando sua disponibilidade máxima. Essa operação complementar das térmicas dependerá, naturalmente, das características de cada usina e, principalmente, de seu custo variável de operação, inclusive sua principal parcela, o custo do combustível.

A lógica econômica impõe o uso prioritário das fontes de menor custo variável de operação. Há, portanto, para cada fonte de geração, um valor para o fator de capacidade (razão entre a produção efetiva e a capacidade instalada) que se justifica do ponto de vista energético e econômico. Esse valor é, naturalmente, condicionado por restrições físicas e técnicas ou, eventualmente, regulatórias e comerciais.

Este trabalho tem como objetivo analisar a expansão do setor elétrico com foco no gás natural. Uma das formas para avaliar de forma real a expansão do setor elétrico é pelo estudo dos leilões de energia, neles se caracterizam como os processos da hidroeletricidade e termeletricidade norteiam o cenário da energia brasileira ao longo dos próximos anos. Com base nisso, serão interpretadas as variáveis envolvidas na metodologia de um leilão e identificados parâmetros que formam a cadeia da competitividade das usinas térmicas.

A meta traçada é, em especial, de caracterizar o gás natural como uma fonte cada vez mais importante na matriz brasileira, pois novas reservas foram descobertas e muitas áreas propícias não foram verificadas. Além disso, nossos vizinhos já possuem grandes reservas, e o gás natural é uma excelente ferramenta de integração regional, intensificando o comércio entre Brasil, Bolívia, Venezuela e Peru. E para isso, analisar a inserção do gás natural de forma competitiva e viável na geração termelétrica brasileira.

O estudo está associado ao fomento da sinergia entre as diversas opções de insumos, principalmente no gás natural, gás natural liquefeito (GNL) e as demais matrizes térmicas, o que se dá também nas diferentes políticas governamentais, de projetos antigos e novos. O gás natural é uma grande ferramenta para reduzir a dependência do Brasil de petróleo. 


\section{LEILÕES DE ENERGIA}

\subsection{Aspectos Institucionais}

Durante os anos de 2003 e 2004 o Governo Federal lançou as bases de um novo modelo para o Setor Elétrico Brasileiro. Em termos institucionais, o novo modelo definiu a criação de uma entidade responsável pelo planejamento do setor elétrico a longo prazo (a Empresa de Pesquisa Energética - EPE), uma instituição com a função de avaliar permanentemente a segurança do suprimento de energia elétrica (o Comitê de Monitoramento do Setor Elétrico CMSE) e uma instituição para dar continuidade às atividades do MAE (Mercado Atacadista de Energia), relativas à comercialização de energia elétrica no Sistema Interligado (a Câmara de Comercialização de Energia Elétrica - CCEE). Outras alterações importantes incluem a definição do exercício do Poder Concedente ao Ministério de Minas e Energia (MME) e a ampliação da autonomia do ONS.

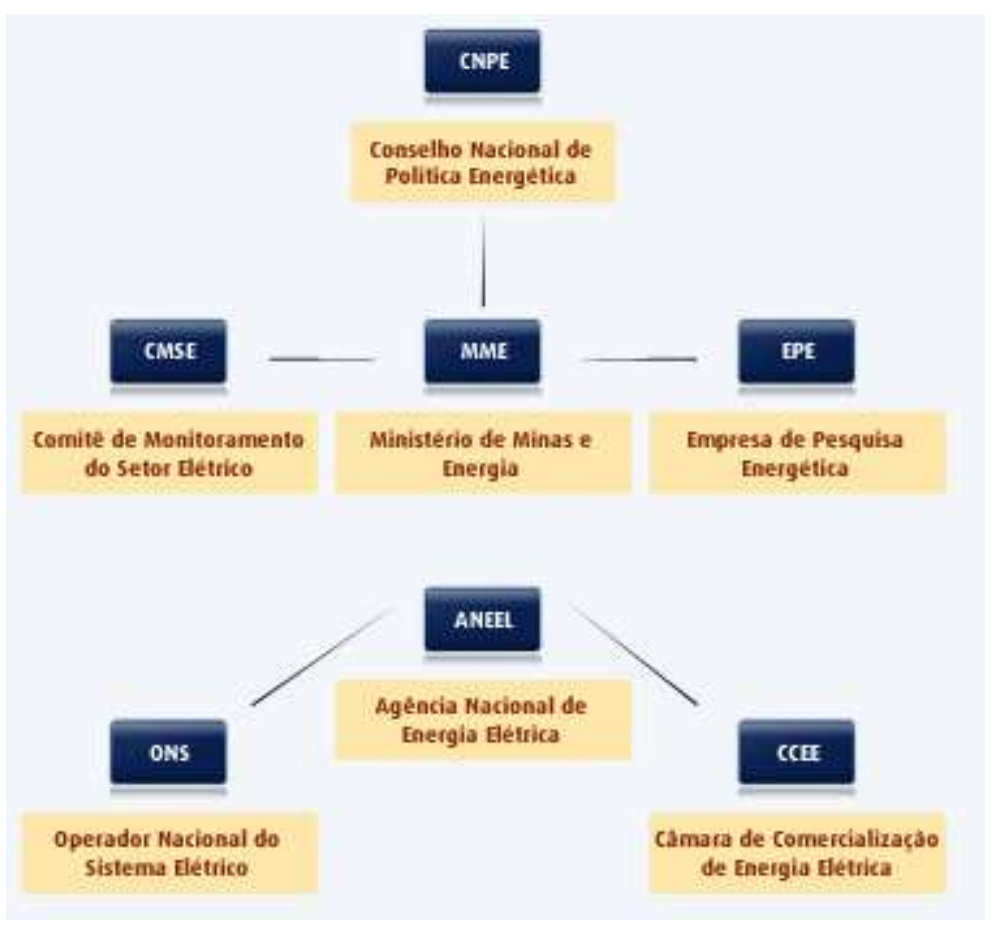

Figura 2.1 - Diagrama das instituições do setor elétrico brasileiro

Fonte: $C C E E$

O CNPE é um órgão de assessoramento do Presidente da República. Dentre as principais formulações de políticas e diretrizes de energia estão as destinadas a:

I. Promover o aproveitamento racional dos recursos energéticos do País; 
II. Assegurar, em função das características regionais, o suprimento de insumos energéticos ás áreas mais remotas ou de difícil acesso do País;

III. Rever periodicamente as matrizes energéticas aplicadas às diversas regiões do País, considerando as fontes convencionais e alternativas e as tecnologias disponíveis;

IV. Estabelecer diretrizes para programas específicos, como os de uso do gás natural, do álcool, de outras biomassas, do carvão e da energia termonuclear.

A lei $n^{\circ}$ 10.847, de 15 de março de 2004 autorizou a criação da Empresa de Pesquisa Energética. Dentre as principais atribuições da EPE estão:

- Realizar estudos e projeções da matriz energética brasileira;

- Identificar e quantificar os potenciais de recursos energéticos;

- Realizar estudos para a determinação dos aproveitamentos ótimos dos potenciais hidráulicos;

- Elaborar estudos necessários para o desenvolvimento dos planos de expansão da geração e transmissão de energia elétrica de curto, médio e longo prazos;

- Promover estudos para dar suporte ao gerenciamento da relação reserva e produção de hidrocarbonetos no Brasil, visando à auto-suficiência sustentável;

- Promover estudos de mercado visando definir cenários de demanda e oferta de petróleo, seus derivados e produtos petroquímicos;

- Desenvolver estudos de impacto social, viabilidade técnico-econômica e sócioambiental para os empreendimentos de energia elétrica e de fontes renováveis;

- Efetuar o acompanhamento da execução de projetos e estudos de viabilidade realizados por agentes interessados e devidamente autorizados;

- Elaborar estudos relativos ao plano diretor para o desenvolvimento da indústria de gás natural no Brasil;

- Dar suporte e participar nas articulações visando à integração energética com outros países;

Os estudos e pesquisas desenvolvidos pela EPE subsidiam a formulação, o planejamento e a implementação de ações do Ministério de Minas e Energia, no âmbito da política energética nacional.

De acordo com os estudos e regras estabelecidos, o novo modelo do setor elétrico visa atingir três objetivos principais:

Garantir a segurança do suprimento de energia elétrica;

> Promover a modicidade tarifária; 
Promover a inserção social no Setor Elétrico Brasileiro, em particular pelos programas de universalização de atendimento.

O modelo prevê um conjunto de medidas a serem observadas pelos Agentes, como a exigência de contratação de toda a demanda por parte das distribuidoras e dos consumidores livres, nova metodologia de cálculo do lastro para venda de geração, contratação de usinas hidrelétricas e termelétricas em proporções que assegurem melhor equilíbrio entre garantia e custo de suprimento, bem como o monitoramento permanente da continuidade e da segurança de suprimento, visando detectar desequilíbrios conjunturais entre oferta e demanda.

Em termos de modicidade tarifária, o modelo prevê a compra de energia elétrica pelas distribuidoras no ambiente regulado por meio de leilões - observado o critério de menor tarifa-, objetivando a redução do custo de aquisição dessa energia a ser repassada para a tarifa dos consumidores cativos.

Em relação à comercialização de energia no Sistema Interligado, foram instituídos dois ambientes para celebração de contratos de compra e venda de energia: o Ambiente de Contratação Regulada (ACR), do qual participam Agentes de Geração e de Distribuição de energia; e o Ambiente de Contratação Livre (ACL), do qual participam Agentes de Geração, Comercializadores, Importadores e Exportadores de energia e Consumidores Livres.

Os Agentes de Geração, assim como os Comercializadores, podem vender energia elétrica nos dois ambientes, mantendo o caráter competitivo da geração, e todos os contratos, sejam do ACR ou do ACL, são registrados na CCEE e servem de base para a contabilização e liquidação das diferenças no mercado de curto prazo.

Uma visão geral da comercialização de energia, envolvendo os dois ambientes de contratação, é apresentada na figura seguinte:

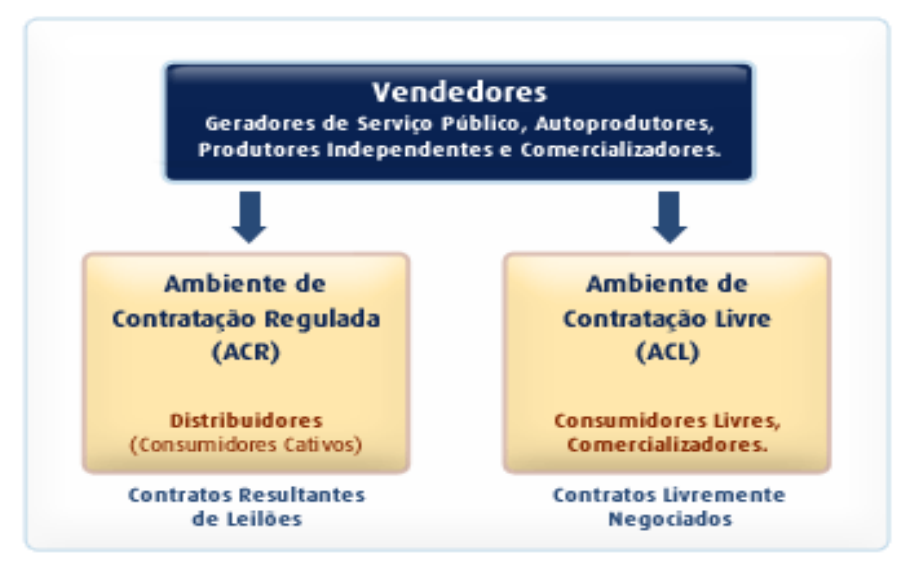

Figura 2.2 - Visão dos ambientes de contratação 
A contratação de energia elétrica no ACL é feita por Contratos Bilaterais livremente pactuados, os quais deverão prever, entre outras disposições, montantes de energia e de potência, prazos, preços e garantias financeiras.

As relações comerciais entre os Agentes participantes da CCEE são regidas predominantemente por contratos de compra e venda de energia, e todos os contratos celebrados entre os Agentes no âmbito do Sistema Interligado Nacional devem ser registrados na CCEE. Esse registro inclui apenas as partes envolvidas, os montantes de energia e o período de vigência; os preços de energia dos contratos não são registrados na CCEE, sendo utilizados especificamente em acordos bilaterais.

A CCEE contabiliza as diferenças entre o que foi produzido ou consumido e o que foi contratado. As diferenças (positivas ou negativas) são liquidadas no Mercado de Curto Prazo e valoradas ao PLD (Preço de Liquidação das Diferenças), determinado semanalmente para cada patamar de carga e para cada submercado, tendo como base o custo marginal de operação do sistema, este limitado por um preço mínimo e por um preço máximo. Dessa forma, pode-se dizer que o mercado de curto prazo é o mercado das diferenças entre montantes contratados e montantes medidos, conforme ilustração que segue:

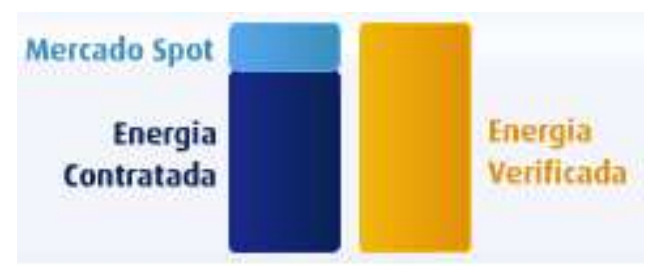

Figura 2.3 - Processo de comercialização de energia

Fonte: CCEE

Principais atribuições da CCEE:

- Manter o registro de todos os contratos fechados nos Ambientes de Contratação Regulada (ACR) e de Contratação Livre (ACL);

- Promover a medição e registro dos dados de geração e consumo de todos os Agentes da CCEE;

- Apurar o Preço de Liquidação de Diferenças - PLD - do Mercado de Curto Prazo por submercado; 
- Apurar o descumprimento de limites de contratação de energia elétrica e outras infrações e, quando for o caso, por delegação da ANEEL, nos termos da Convenção de Comercialização, aplicar as respectivas penalidades;

- Apurar os montantes e promover as ações necessárias para a realização do depósito, da custódia e da execução de Garantias Financeiras, relativas às Liquidações Financeiras do Mercado de Curto Prazo, nos termos da Convenção de Comercialização;

- Promover Leilões de Compra e Venda de energia elétrica, conforme delegação da ANEEL;

- Promover o monitoramento das ações empreendidas pelos Agentes, no âmbito da CCEE, visando à verificação de sua conformidade com as Regras e Procedimentos de Comercialização, e com outras disposições regulatórias, conforme definido pela ANEEL.

\subsection{Agentes da CCEE}

São agentes com participação obrigatória na CCEE:

I - os concessionários, permissionários ou autorizados de geração que possuam central geradora com capacidade instalada igual ou superior a $50 \mathrm{MW}$;

II - os autorizados para importação ou exportação de energia elétrica com intercâmbio igual ou superior a $50 \mathrm{MW}$;

III - os concessionários, permissionários ou autorizados de serviços e instalações de distribuição de energia elétrica cujo volume comercializado seja igual ou superior a 500 GWh/ano, referido ao ano anterior;

IV - os concessionários, permissionários ou autorizados de serviços e instalações de distribuição de energia elétrica cujo volume comercializado seja inferior a $500 \mathrm{GWh} / \mathrm{ano}$, referido ao ano anterior, quando não adquirirem a totalidade da energia de supridor com tarifa regulada;

V - os autorizados de comercialização de energia elétrica, cujo volume comercializado seja igual ou superior a $500 \mathrm{GWh} / \mathrm{ano}$, referido ao ano anterior; e

VI - os Consumidores Livres e os consumidores que adquirirem energia na forma do $\S 5^{\circ}$ do art. 26 da Lei no 9.427, de 26 de dezembro de 1996.

São Agentes com participação facultativa na CCEE:

- Os titulares de autorização para autoprodução e co-geração com central geradora de capacidade instalada igual ou superior a $50 \mathrm{MW}$, desde que suas instalações de geração estejam diretamente conectadas às instalações de consumo e não sejam despachadas de 
modo centralizado pelo ONS, por não terem influência significativa no processo de otimização energética dos sistemas interligados.

- Demais titulares de concessão ou autorização para exploração de serviços de geração, para realização de atividades de comercialização de energia elétrica, bem como para importação e exportação de energia.

Os Agentes da CCEE dividem-se nas Categorias de Geração, de Distribuição e de Comercialização, conforme definido na Convenção de Comercialização.

\subsubsection{Geração}

Representa a Categoria dos Agentes Geradores, Produtores Independentes e AutoProdutores. A atividade de geração de energia elétrica permanece com seu caráter competitivo, sendo que todos os Agentes de Geração poderão vender energia tanto no ACR como no ACL. Os Geradores também possuem livre acesso aos sistemas de transmissão e distribuição de energia elétrica.

Os Agentes de Geração podem ser classificados em:

\section{- Concessionários de Serviço Público de Geração}

Agente titular de Serviço Público Federal delegado pelo Poder Concedente mediante licitação, na modalidade de concorrência, à pessoa jurídica ou consórcio de Empresas para exploração e prestação de serviços públicos de energia elétrica, nos termos da Lei 8.987, de 13 de fevereiro de 1995.

\section{- Produtores Independentes de Energia Elétrica}

São Agentes individuais ou reunidos em consórcio que recebem concessão, permissão ou autorização do Poder Concedente para produzir energia elétrica destinada à comercialização por sua conta e risco.

\section{- Auto-Produtores}

São Agentes com concessão, permissão ou autorização para produzir energia elétrica destinada a seu uso exclusivo, podendo comercializar eventual excedente de energia, desde que autorizado pela ANEEL.

\subsubsection{Distribuição}


Enumera a Categoria dos Agentes Distribuidores dentro da atividade de distribuição orientada para o serviço de rede e de venda de energia aos consumidores com tarifa e condições de fornecimento reguladas pela ANEEL (Consumidores Cativos). Com o novo modelo, os distribuidores têm participação obrigatória no ACR, celebrando contratos de energia com preços resultantes de leilões.

\subsubsection{Comercialização}

Categoria dos Agentes Importadores e Exportadores, Comercializadores e Consumidores Livres.

\section{- Importadores}

São os Agentes do setor que detêm autorização do Poder Concedente para realizar importação de energia elétrica para abastecimento do mercado nacional.

\section{- Exportadores}

São os Agentes do setor que detêm autorização do Poder Concedente para realizar exportação de energia elétrica para abastecimento de países vizinhos.

\section{- Comercializadores}

Os Agentes Comercializadores de energia elétrica compram energia através de contratos bilaterais celebrados no ACL, podendo vender energia aos consumidores livres, no próprio ACL, ou aos distribuidores através dos leilões do ACR.

\section{- Consumidores Livres}

São consumidores que, atendendo aos requisitos da legislação vigente, podem escolher seu fornecedor de energia elétrica (geradores e comercializadores) por meio de livre negociação.

A partir de 1998, conforme regulamenta a Lei $n^{\circ} 9.427$, parágrafo $5^{\circ}$, art. 26, de 26 de dezembro de 1996, os consumidores com demanda mínima de $500 \mathrm{~kW}$, atendidos em qualquer tensão de fornecimento, têm também o direito de adquirir energia de qualquer fornecedor, desde que a energia adquirida seja oriunda de Pequenas Centrais Hidrelétricas (PCHs) ou de fontes alternativas (eólica, biomassa ou solar).

\subsection{Classificações dos Leilões}

A Lei no 10.848, de 15 de março de 2004, autorizou a criação da Câmara de Comercialização de Energia Elétrica - CCEE, pessoa jurídica de direito privado, sem fins lucrativos, sob autorização do Poder Concedente e regulação e fiscalização pela ANEEL, com a finalidade de viabilizar a comercialização de energia elétrica entre concessionários, permissionários e autorizados de serviços e instalações de energia elétrica, bem como desses 
com seus consumidores, no Sistema Interligado Nacional - SIN, mediante contratação regulada ou livre, nos termos da Lei e do seu regulamento; compete à ANEEL a regulação da comercialização de energia elétrica, em especial mediante a expedição da Convenção de Comercialização, das Regras e dos Procedimentos de Comercialização.

As Regras de Comercialização são um conjunto de equações matemáticas e fundamentos conceituais, complementares e integrantes à Convenção de Comercialização de Energia Elétrica, instituída pela Resolução Normativa ANEEL n ${ }^{\circ}$ 109, de 26 de outubro de 2004, que associadas aos seus respectivos Procedimentos de Comercialização, estabelecem as bases necessárias para a operação comercial da CCEE e estipulam o processo de contabilização e liquidação. A comercialização de energia elétrica entre os Agentes da CCEE, bem como destes com os consumidores no Sistema Integrado Nacional, dar-se-á no ACR ou ACL e no Mercado de Curto Prazo segundo direitos e obrigações abordados na Convenção de Comercialização.

Os leilões de energia elétrica organizados pelo governo visam ao atendimento do mercado consumidor das distribuidoras de energia elétrica e são classificados de acordo com a natureza dos empreendimentos de geração.

- Leilões de Energia Existente: empreendimentos que já se encontram em operação;

- Leilões de Energia Nova: novos empreendimentos licitados;

- Leilões de Fontes Alternativas: empreendimentos que utilizam fontes alternativas (biomassa, PCH, solar, eólica).

Com base nisso os leilões tendem a acompanhar o desenvolvimento da geração e da diversificação de matrizes do país, observando a as características do panorama e de planos como o Plano Decenal de Energia, desenvolvido pelo governo com o intuito de observar os vários enfoques da geração, distribuição, tarifa, impacto ambiental e social, etc. Nesse plano são observados parâmetros de médio prazo num período de 10 anos.

Nessa ótica, a figura 2.4 demonstra a evolução da energia contratada e demandada por elementos por leilões de energia existente. Observa-se que ela varia de acordo com as tendências de mercado, além do estudo da viabilidade das próprias usinas. Isso implica na disputa por mercados, além de uma competitividade entre distribuidoras estatais e privadas. Vale ressaltar que a evolução está caracterizada do $1^{\circ}$ leilão de energia de 2004 até o $6^{\circ}$ leilão de 2007. Não inclui as fontes alternativas e a energia nova. 


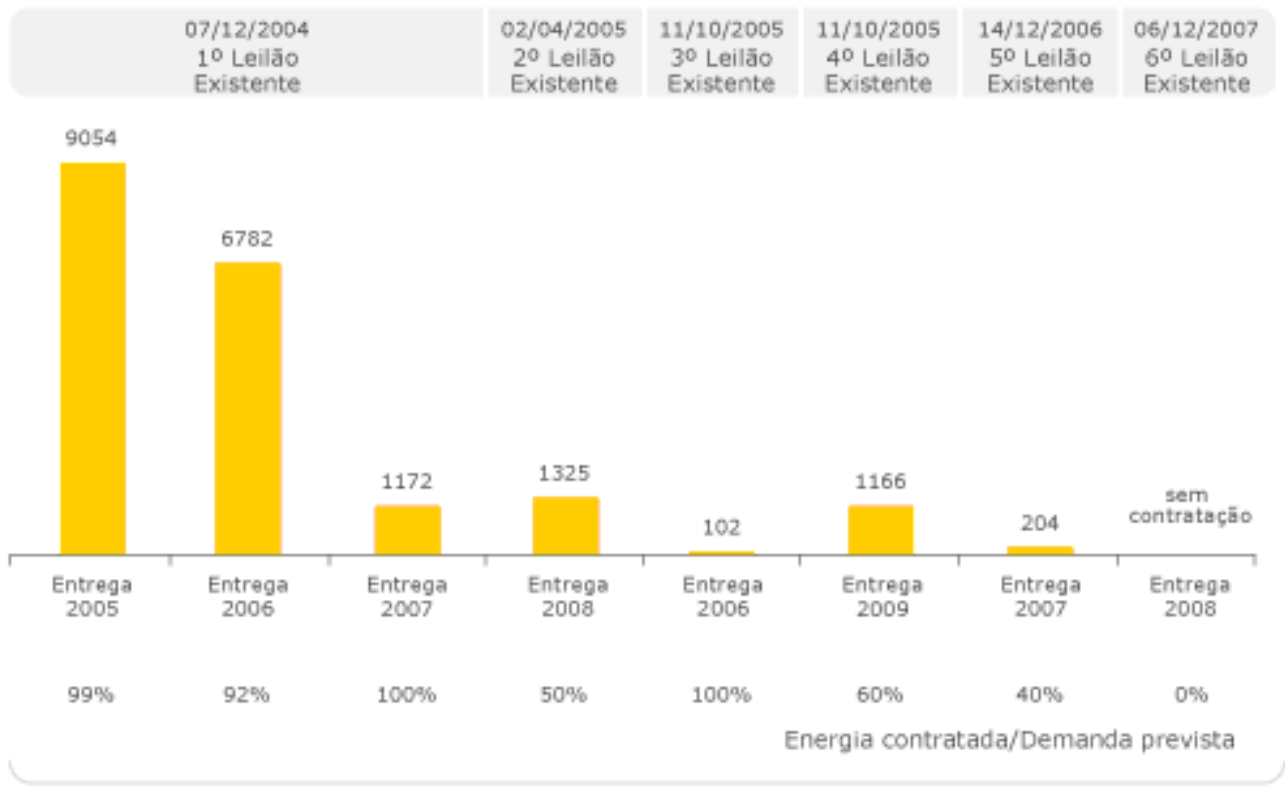

Fig. 2.4 - Leilões de Energia Existente

Fonte: Instituo Acende Brasil, 2007.

O leilão de energia existente estabelece o abastecimento geral; para crescimento e desenvolvimento da matriz há de ser ponderado o leilão de energia nova e de fontes alternativas.

Os leilóes de fontes alternativas estão associados ao progresso tecnológico e à necessidade da diversificação da matriz energética brasileira. Nessa ótica estão ainda em caráter inicial. Todavia, já norteiam resultados, ainda que incipientes, mas importantes como recursos que podem ser essenciais no futuro.

Nos leilões de energia nova, os empreendimentos hídricos e térmicos são leiloados separadamente. Os hídricos são contratados sob regime de concessão por 30 anos e os térmicos, sob o regime de autorização por 15 anos. Há uma etapa do leilão na qual são negociados preços de venda da energia e outra etapa na qual são negociadas as quantidades em lotes de energia para o ACR.

É importante destacar que os empreendimentos hídricos têm o objetivo de atender à base da curva de carga diária de energia elétrica, enquanto os empreendimentos térmicos operam, preferencialmente, para atender ao pico da curva de carga ou para atender à demanda durante o período de estiagem. 
Há duas informações importantes sobre quantidades. Primeiro, as garantias físicas dos empreendimentos leiloados são informações que mostram o total de energia adicional que poderá ser ofertado em cada ano. Segundo, os lotes negociados nos leilões são informações necessárias para verificar o atendimento da demanda cativa das distribuidoras de energia elétrica. A diferença entre garantia física e lotes negociados é a energia excedente que poderá ser negociada no ACL ou nos leilões de ajuste (leilões de energia existente "A-1"), que ocorrem todo ano.

A análise da expansão do sistema elétrico está intimamente ligada à contratação de energia nova em termos de quantidade de energia, para isso é de suma importância a avaliação dos resultados do leilão de energia nova.

\subsection{Funcionamento dos Leilões}

Aqui serão abordadas as regras e o mecanismo básicos dos leilões de acordo com os editais A-3 e A-5 de 2008.

Antes do leilão, a CCEE inserirá no sistema o preço de referência de cada empreendimento, o percentual mínimo da garantia física de cada empreendimento UHE, o preço teto da primeira fase, o custo marginal de referência, os preços iniciais da segunda fase para os produtos hídricos e outras fontes, os próprios produtos, tipo do combustível, submercado, proponente vendedor, enfim todas as informações que caracterizam o cenário disponível e seus participantes.

O sistema processará os dados e fornecerá algumas características dos empreendimentos para que essas informações sejam confirmadas pelos empreendedores.

O leilão é realizado via sistema eletrônico, mediante o emprego de recursos de tecnologia da informação disponibilizado pela Internet, e será composto de duas fases, as quais se dividem da seguinte forma:

I. Primeira fase - Divide-se em rodadas uniformes e rodada discriminatória;

II. Segunda fase - Divide-se em etapa hídrica e etapa outras fontes. Por sua vez, cada uma dessas etapas é subdividida em rodadas uniformes e rodada discriminatória. 
A $1^{\text {a }}$ Fase caracteriza-se pela disputa do direito de participação de um empreendedor UHE na segunda fase e a $2^{a}$ Fase pela disputa entre empreendimentos UHEs vencedores na primeira fase, empreendimentos PCHs habilitados e empreendimentos Outras Fontes habilitados. Não haverá primeira fase para o leilão A-3.

Na primeira fase do leilão o lance deverá conter o preço de lance, que é um preço menor ou igual ao preço inicial da primeira fase. Nessa fase poderá haver etapa contínua seguida da etapa inicial, para cada empreendimento UHE, caso haja empreendedores com preços de lance no máximo 5\% maiores que o menor preço de lance de um empreendedor.

Nas rodadas uniformes há a submissão de lances dos empreendimentos com quantidades associadas ao preço de lance. Na rodada discriminatória há submissão de um único lance com preço de lance associado à quantidade de lotes classificada para a respectiva etapa.

A rodada uniforme persiste até que a quantidade ofertada do produto seja maior ou igual à oferta de referência do produto.

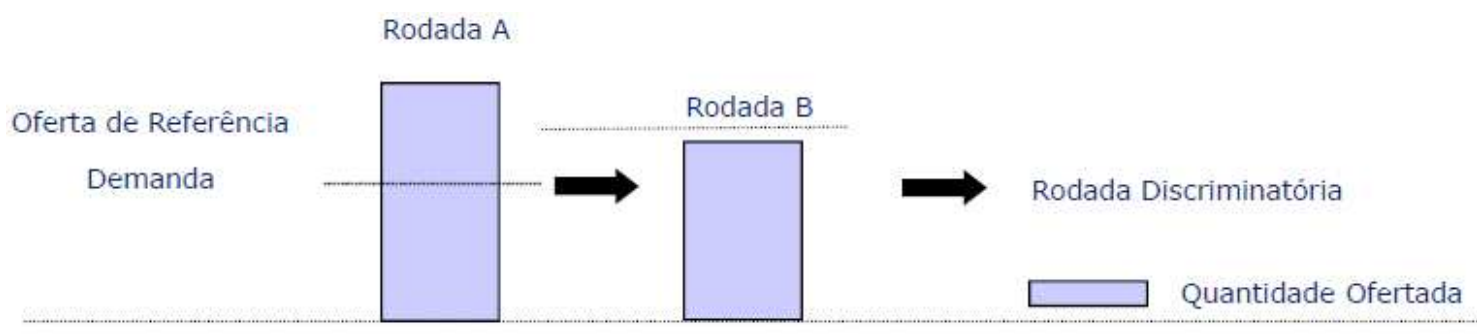

Fig. 2.5 - Rodadas Uniformes

Fonte: CCEE

Durante a rodada discriminatória da etapa hídrica, o lance deverá especificar o valor pelo qual está disposto e apto a ofertar a totalidade de seus lotes, enquanto que a rodada discriminatória da etapa outras fontes o lance deverá explicitar a receita fixa pela qual está disposto e apto a ofertar a totalidade de lotes da rodada uniforme. 


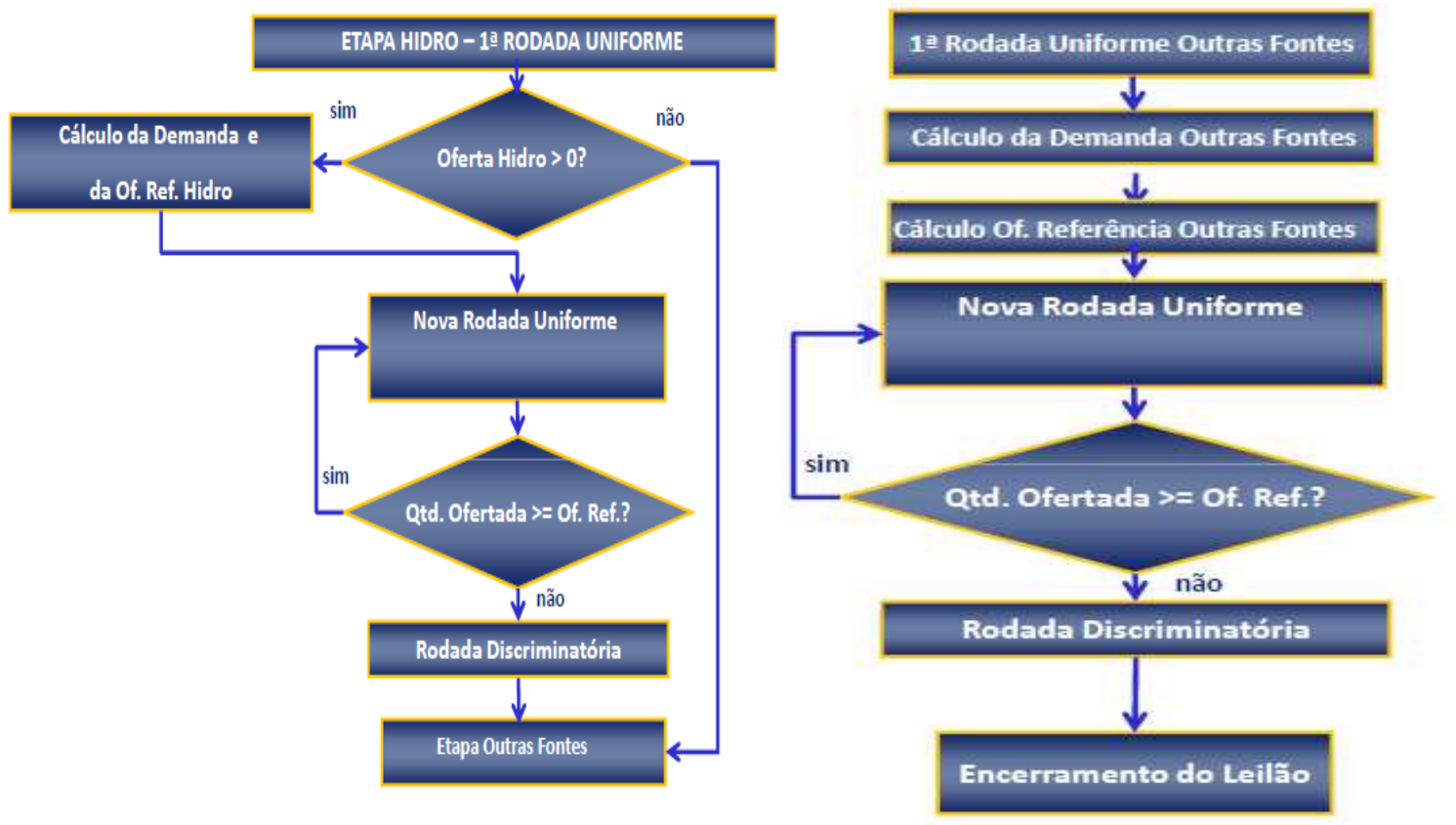

Fig. 2.6 - Visão Geral das Etapas

Fonte: $C C E E$

\subsection{Análise dos Leilões de Energia Nova}

Baseando-se na expansão do parque energético brasileiro, a caracterização dos leilões de energia elucida a previsão para o balanço energético dos períodos decorrentes de 2008 até 2013, estabelecendo os parâmetros da energia contratada, os lotes vendidos e a garantia física, bem como demonstra a diferenciação da matriz energética brasileira, em termos hídricos e térmicos. Dentro desse ponto de vista, será observada a evolução dos leilões de energia nova. E um apontamento já a ser destacado é a sua preponderância térmica.

\subsubsection{Primeiro Leilão de Energia Nova}

Foi realizado o primeiro leilão de energia nova, em dezembro de 2005, no âmbito do ambiente de contratação regulada (ACR). As unidades selecionadas foram de geração hidrelétrica e termelétrica, com entrada em operação prevista para o período de 2008 a 2010. No período em questão, serão adicionados ao sistema 5.607 MW médios de garantia física, sendo 3.011 MW médios de geração termelétrica e 2.596 MW médios de geração hidrelétrica.

Uma parcela dessa garantia física (3.284 MW médios) foi comercializada no primeiro leilão com contratos de longo prazo. A tabela $2.1 \mathrm{e}$ a figura 2.7 representam o enquadramento dos resultados desse leilão. 
Tabela 2.1 - Primeiro Leilão 16.12.2005 (MW Médio)

\begin{tabular}{|l|c|c|c|c|c|c|c|}
\hline Fonte & \multicolumn{3}{|c|}{ Hídrica } & \multicolumn{3}{c|}{ Térmica } & Total \\
\hline $\begin{array}{l}\text { Entrada em } \\
\text { operação }\end{array}$ & 2008 & 2009 & 2010 & 2008 & 2009 & 2010 & $2008-2010$ \\
\hline Lotes vendidos & 71 & 46 & 889 & 561 & 855 & 862 & 3284 \\
\hline Garantia Física & & 2596 & & & 3011 & & 5607 \\
\hline $\begin{array}{l}\text { Energia para } \\
\text { ACL }\end{array}$ & & 1590 & & & 733 & & 2323 \\
\hline
\end{tabular}

Fonte: BNDES Setorial - Leilão de Energia Nova - Análise e Sistemática de Resultados 2008

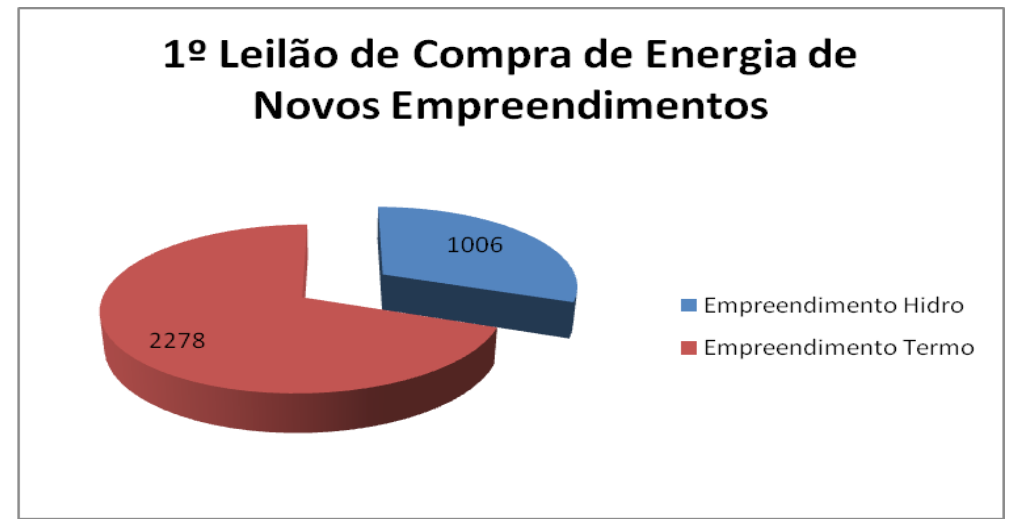

Fig. 2.7 - Quantidade de lotes comercializados no $1^{\circ}$ Leilão de Energia de Compra de Energia Nova

O primeiro leilão dessa nova modalidade, a energia nova, possuiu características da energia "velha", pois representou a outorga de concessões já estabelecidas anteriormente nos leilões da energia existente. Nesse leilão revelou-se o processo de desenvolvimento da nova geração brasileira.

O Instituto Ilumina (Instituto de Desenvolvimento Estratégico do Setor Energético) o qualificou de forma peculiar "este é um dos 'esqueletos no armário' que ainda falta ser posto para fora pela legislação do novo modelo do setor elétrico". Isso significa que nesse leilão a proposta principal era procurar colocar contratualmente no ambiente de contratação regulada (ACR) a energia ainda descontratada de empreendimentos de geração existentes, provenientes de usinas termoelétricas (com todos os tipos possíveis de combustível, como gás natural, carvão mineral, biomassa, diesel, etc.), e também de algumas hidrelétricas já construídas ou ainda em construção, do que propriamente tratar de encontrar no mercado os possíveis donos das outorgas de novas usinas hidroelétricas, que ainda são as que podem produzir energia mais barata no Brasil.

A partir desse leilão, ficou evidenciada cada vez maior a necessidade da sociedade fazer uma opção entre a energia hidrelétrica, mais barata e que tem muitos impactos ambientais associados a sua instalação, e outra mais cara, com impactos ambientais restritos à emissão de gases de efeito estufa, que é a de origem térmica (a de origem nuclear não tem este efeito, mas 
gera resíduos radioativos). Essa constatação é que deu o embasamento dos leilões seguintes, na relação de "trade off" da energia brasileira.

Os leilões A-3 e A-5 foram realizados separadamente, no ano seguinte. Em junho de 2006 foi realizado o segundo leilão (A-3) para a contratação de energia nova para 2009. Logo em seguida, em outubro de 2006, realizou-se o terceiro leilão de energia nova para a entrega de energia no período de 2011 (A-5).

\subsubsection{Segundo e Terceiro Leilões de Energia Nova}

O segundo leilão de energia nova (A-3) comercializou 1.682 MW médios de energia, superando a demanda informada pelas empresas distribuidoras, que foi de $1.616 \mathrm{MW}$ médios. A energia hidrelétrica predominou, somando 1.028 MW médios (61\%) entre os 15 empreendimentos contratados, contra 654 MW médios (39\%) dos 16 empreendimentos de fonte termelétrica contratados. Em termos de garantia física, os empreendimentos negociados no segundo leilão adicionarão ao sistema, a partir de 2009, 4.122 MW médios, dos quais cerca de 2.440 MW médios serão posteriormente negociados.

Segundo a empresa de Consultoria de Energia Elétrica Duke Energy Brasil: "esse leilão foi a real 'prova de fogo' desse novo modelo para o sistema elétrico brasileiro". Neste leilão ofertaram-se a energia das usinas do complexo do Rio Madeira (Usinas de Santo Antônio e Girau). O complexo do rio Madeira é um dos chamados "projetos estruturantes" mais importantes do atual governo federal, não só na área de infra-estrutura de energia elétrica, como também na área de transporte para a produção agro-industrial da região que envolve os interesses nacionais de três países da América do Sul (Brasil, Bolívia e Peru).

Com base nessa configuração, a caracterização hidráulica foi superior à térmica para alicerçar as bases para uma possível construção futura de usinas hidrelétricas junto à Bolívia em expansão para os Andes.

Já no terceiro leilão de energia nova (A-5), da demanda de 1.243 MW médios informada pelas empresas de distribuição, $1.104 \mathrm{MW}$ médios foram contratados no leilão, o que equivale ao atendimento de $88,8 \%$ do mercado estimado para 2011 pelas distribuidoras. A energia hidrelétrica predominou novamente, mas a participação percentual das térmicas aumentou consideravelmente em relação ao segundo leilão: 51,54\% (569 MW médios) dos seis empreendimentos hídricos contratados, contra 48,46\% (535 MW médios) dos nove empreendimentos termelétricos contratados. A tabela 2.2 demonstra a comparação entre ambos leilões e a figura 2.8 elucida os novos empreendimentos do segundo leilão. 
Tabela 2.2 - Segundo Leilão (A-3) - 29.6.2006 e Terceiro Leilão (A-5)-10.10.2006 (MW Médios)

\begin{tabular}{|c|c|c|c|c|c|c|}
\hline \multirow{3}{*}{\begin{tabular}{|l|} 
Entrada em \\
Operação \\
Fonte
\end{tabular}} & \multicolumn{3}{|c|}{$\begin{array}{c}\text { Segundo Leilão (A-3): } \\
\text { 29.6.2006 }\end{array}$} & \multicolumn{3}{|c|}{$\begin{array}{c}\text { Terceiro Leilão (A-5): } \\
10.10 .2006\end{array}$} \\
\hline & \multicolumn{3}{|c|}{2009} & \multicolumn{3}{|c|}{2011} \\
\hline & Hídrica & Térmica & Total & Hídrica & Térmica & Total \\
\hline Lotes vendidos & 1028 & 654 & 1682 & 569 & 535 & 1104 \\
\hline Garantia Física & 2951 & 1171 & 4122 & 656 & 1272 & 1928 \\
\hline Energia para $A C L$ & 1923 & 517 & 2440 & 87 & 737 & 824 \\
\hline
\end{tabular}

Fonte: BNDES Setorial - Leilão de Energia Nova - Análise e Sistemática de Resultados 2008

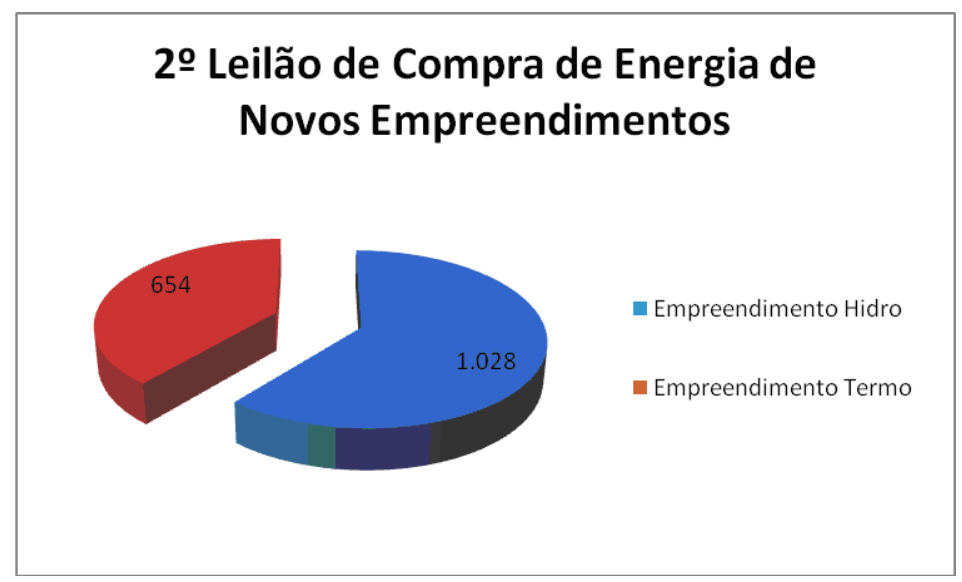

Fig. 2.8 - Quantidade de lotes comercializados no $2^{\circ}$ Leilão de Energia de Compra de Energia Nova

O terceiro leilão adicionará 1.928 MW médios de garantia física, em 2011, quantidade significativamente inferior aos leilões anteriores. As unidades de geração hidrelétrica comercializaram no leilão quase toda a garantia física disponível, restando apenas $87 \mathrm{MW}$ médios para serem negociados posteriormente. Nota-se, contudo, que houve diminuição da oferta dessa fonte ao sistema em relação aos leilões anteriores, como se evidencia na figura 2.9. Em geração termelétrica, menos da metade da garantia física disponível foi contratada, restando 737 MW médios para serem comercializados.

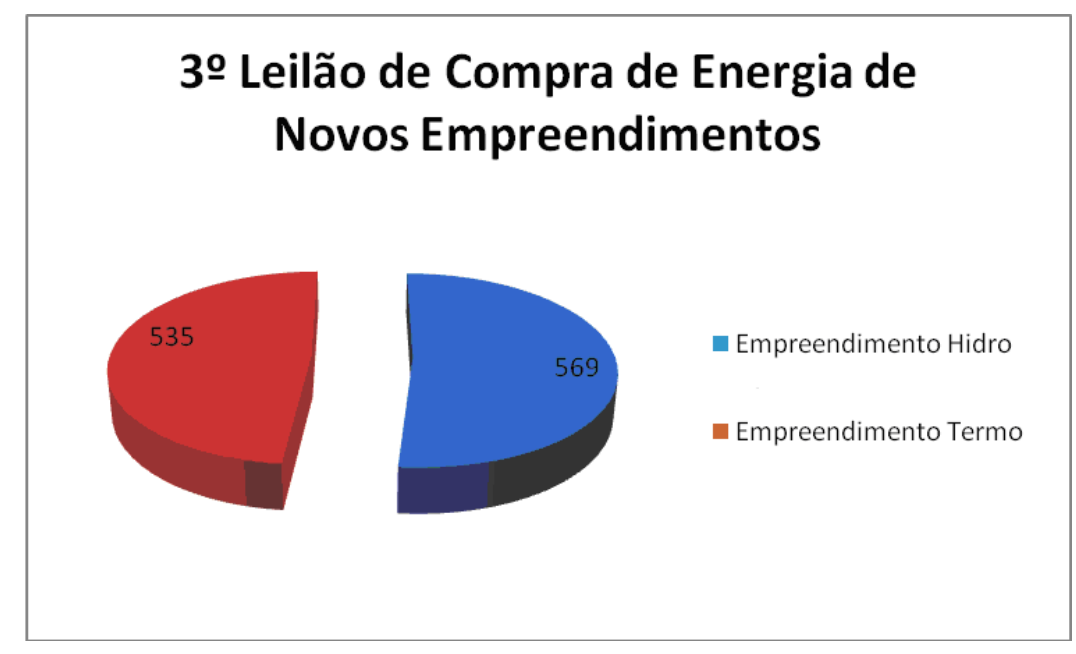


Fig. 2.9 - Quantidade de lotes comercializados no $3^{\circ}$ Leilão de Energia de Compra de Energia Nova

Verificou-se a manutenção de algumas das características dos outros dois certames. Primeiramente, os baixos preços-teto fixados para as concessões de novas hidrelétricas não atraíram investidores privados, e estes empreendimentos acabaram sendo mais uma vez adquiridos por consórcios com forte participação de empresas estatais ou fundos de pensão de empresas estatais. Este contexto conduz ao segundo aspecto comum aos leilões, que é a participação relativamente alta de usinas térmicas considerando o alto potencial hídrico do Brasil.

A partir dos avanços significativos das outras matrizes (biomassa e eólica) em junho de 2007, foi realizado um leilão específico para fontes alternativas (FA), para o qual foram habilitadas usinas de geração a biomassa, eólica e pequenas centrais hidrelétricas (PCH).

\subsubsection{Leilão de Fontes Alternativas}

O principal objetivo do Leilão $\boldsymbol{F A}$ foi a negociação das PCHs com outorgas da ANEEL. A preocupação da Agência estava com as negociações de outorgas de $\mathrm{PCH}$ e, principalmente, com o baixo interesse dos empreendedores em iniciar a construção das usinas. A alegação dos detentores das outorgas era de que eles não tinham para quem vender a energia.

Com isso, o governo realizou um leilão específico e incluiu as fontes biomassa e eólica. Os contratos para as PCH foram por quantidade por 30 anos, seguindo a lógica dos empreendimentos hídricos, e os contratos termelétricos e eólicos, por disponibilidade por 15 anos.

A inclusão da energia eólica foi uma tentativa do Leilão $F A$, sendo a primeira oportunidade para esse tipo de geração após o início do Programa de Fontes Alternativas (Proinfa), lançado em 2002. Conforme pode ser visto na tabela 2.3 e na figura 2.10, dos 2.803 MW habilitados pela EPE a participar do leilão FA, a oferta de energia eólica foi de $939 \mathrm{MW}$.

Tabela 2.3 - Empreendimentos Habilitados FA

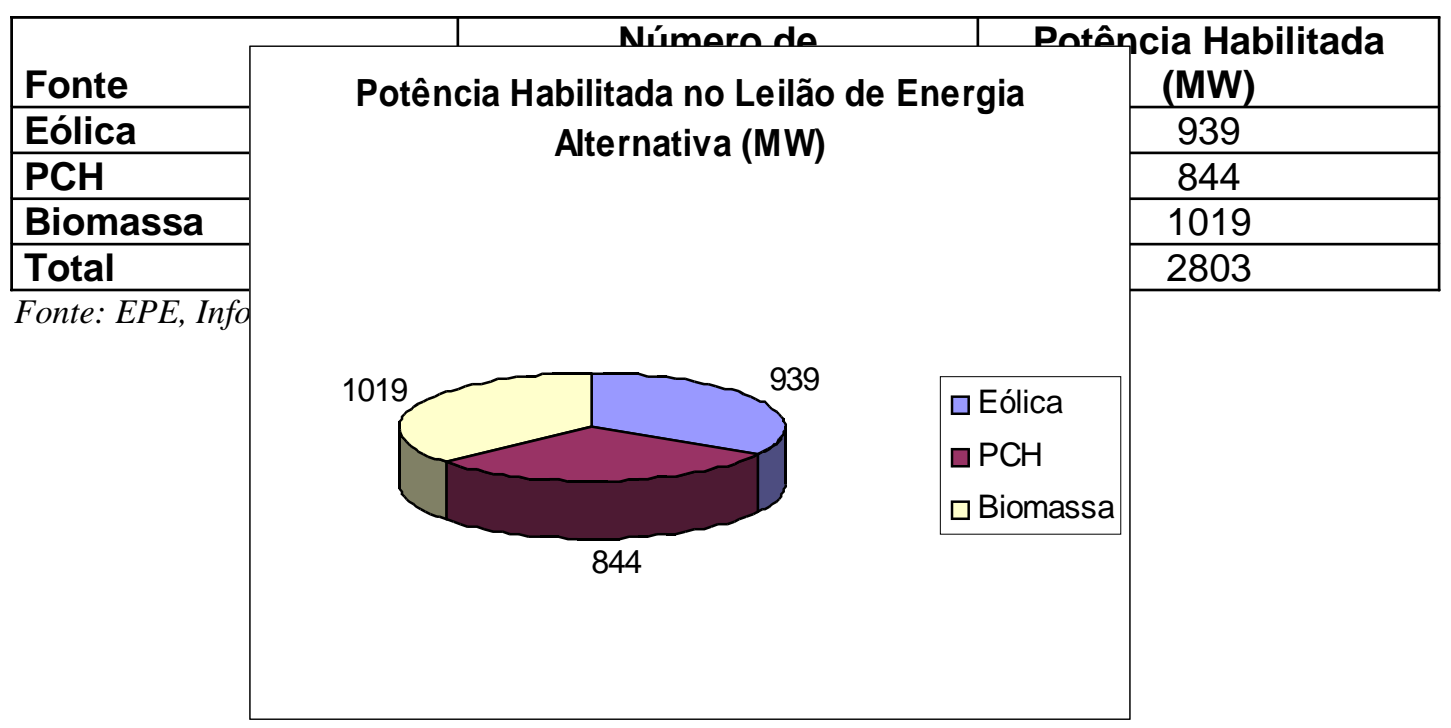


Fig. 2.10 - Comparação da potência relacionada no Leilão de Energia Alternativa

Todavia, o que se notou foi que o preço-teto e o contrato por disponibilidade por 15 anos não viabilizavam os empreendimentos eólicos. Por mais que existisse um grande interesse de investidores, nenhum empreendimento eólico se pré-qualificou para participar do certame.

As usinas eólicas apresentam características similares às hídricas, como a sazonalidade de geração, elevados custos fixos e baixo custo operacional. Seria muito arriscado para o empreendedor estimar a disponibilidade média de uma usina cuja força motriz é variável, o vento. Em síntese, o leilão FA permitiu a participação de usinas eólicas, mas as condições contratuais não foram favoráveis aos empreendedores.

O atendimento do leilão visou ao mercado das distribuidoras para o ano de 2010. A contratação foi de apenas $186 \mathrm{MW}$ médios de energia, sendo $75 \%$ de biomassa e $25 \%$ de PCH. Em garantia física, serão adicionados ao sistema cerca de $283 \mathrm{MW}$ médios, dos quais $70 \mathrm{MW}$ médios oriundos de PCH (seis empreendimentos) e 214 MW médios de biomassa (12 empreendimentos). Entre as usinas a biomassa contratadas, 11 empreendimentos têm como combustível o bagaço de cana, somando $86 \%$ do total térmico, e os $14 \%$ restantes são de um empreendimento com combustível de biomassa avícola. Do total de garantia física, apenas $65 \%$ dessa energia foi contratada no leilão, restando $74 \mathrm{MW}$ médios de fonte de biomassa e $24 \mathrm{MW}$ médios de fonte de PCHs para serem futuramente comercializados.

A baixa participação de PCH (principal foco do leilão), a não-participação de fonte eólica (nenhuma pré-qualificada) e a venda de apenas $65 \%$ da garantia física das usinas mostram que o leilão FA não atendeu às expectativas do governo e tampouco dos empreendedores.

Esse resultado com a tentativa do governo da inserção de novas matrizes no certame dos leilões demonstrou ainda a fragilidade das bases dessas fontes alternativas, logo esse leilão representou uma etapa inicial para a tentativa futura de outros possíveis leilões desses modernos 
recursos. Vale ressaltar que não há um peso significativo na matriz energética tanto em termos da garantia física adicionada, quanto nos números de empreendimentos associados.

Em 2007, além do leilão FA, foram realizados o quarto e o quinto leilões que representaram a confirmação da orientação no sentido térmico.

\subsubsection{Quarto e Quinto Leilões de Energia Nova}

O quarto leilão de energia nova (A-3) ocorreu em julho de 2007, com início de suprimento de energia programado para 2010. Quase toda a garantia física (1.318 MW médios) foi contratada, mas o resultado do leilão surpreendeu porque nenhuma das hidrelétricas habilitadas foi negociada.

O resultado desse leilão consolida uma tendência já exibida nos certames passados de a matriz elétrica brasileira tornar-se cada vez mais poluidora e mais cara a cada leilão. Conforme mostra a figura 2.11, dos 7.376 MW médios negociados nos quatro leilões, $65 \%$ tem origem térmica. Fato ainda mais preocupante neste último leilão é que as usinas contratadas são a óleo combustível, estando entre as mais sujas.

Assim, o Brasil segue caminho inverso dos países desenvolvidos, que buscam aumentar a participação de fontes mais limpas em suas matrizes de geração elétrica que se demonstra na tabela 2.4.

Tabela 2.4 - Quarto Leilão (A-3) - 26.7.2007 e Quinto Leilão (A-5)-16.10.2007 (MW Médios)

\begin{tabular}{|l|c|c|c|c|c|c|}
\cline { 2 - 7 } \multicolumn{1}{c|}{} & \multicolumn{3}{c}{ Quarto Leilão (A-3): } & \multicolumn{3}{c|}{ Quinto Leilão (A-5): } \\
\multicolumn{1}{l|}{$\begin{array}{l}\text { 26.7.2007 } \\
\text { Entrada em } \\
\text { Operação }\end{array}$} & \multicolumn{3}{|c|}{$\mathbf{2 0 1 0}$} & \multicolumn{3}{c|}{$\mathbf{2 0 1 2}$} \\
\hline Fonte & Hídrica & Térmica & Total & Hídrica & Térmica & Total \\
\hline Lotes vendidos & 0 & 1304 & 1304 & 715 & 1597 & 2312 \\
\hline Garantia Física & 0 & 1318 & 1318 & 1325 & 1695 & 3020 \\
\hline Energia para ACL & 0 & 14 & 14 & 610 & 98 & 708 \\
\hline
\end{tabular}

Fonte: BNDES Setorial - Leilão de Energia Nova - Análise e Sistemática de Resultados 2008 


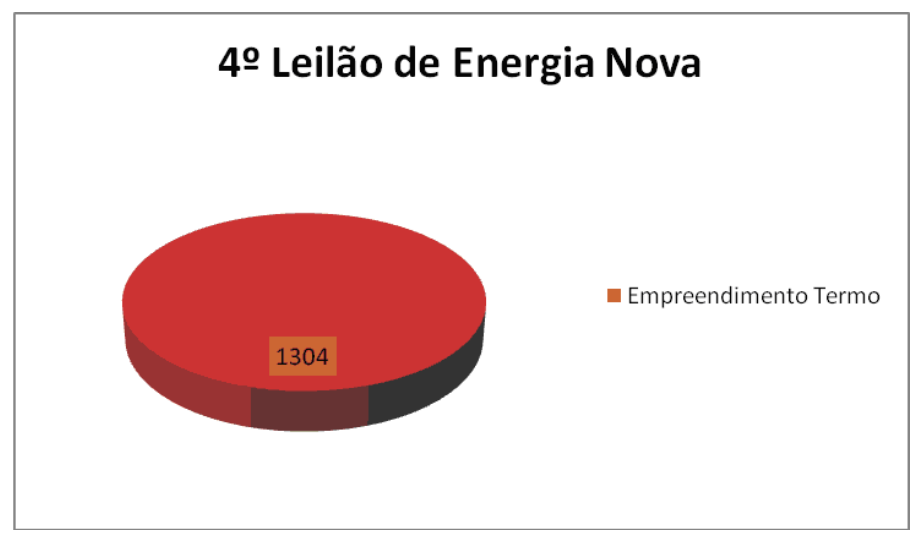

Fig. 2.11 - Quantidade de lotes comercializados no $4^{\circ}$ Leilão de Energia de Compra de Energia Nova

O quinto leilão (A-5) foi realizado em outubro de 2007, com início de suprimento de energia para 2012. Foram vendidos 2.312 lotes, restando 708 lotes para serem negociados posteriormente. Os empreendimentos, em termos de garantia física, contratados no quinto leilão fornecerão 3.020 MW médios para o sistema elétrico, dos quais 1.325 MW médios são hídricos e 1.695 MW médios são termelétricos. Entre os termelétricos, 964 MW médios são provenientes de carvão mineral, 401 MW médios de gás natural e 330 MW médios de óleo combustível. Os resultados do leilão mostram mais uma vez a escassez de oferta hidrelétrica como se caracteriza a figura 2.12, uma vez que os preços fixados não atraíram investidores e que novas hidrelétricas também não entraram em operação.

Com base na Análise Pós $5^{\circ}$ Leilão do Instituo Acende Brasil, nesse leilão de energia nova, verificaram-se pontos positivos. O primeiro foi o pleno atendimento da demanda informada pelas distribuidoras. O segundo ponto diz respeito ao retorno da venda de energia hidrelétrica, após a completa ausência destas usinas nos resultados do quarto leilão. Outro avanço foi a estréia das térmicas a carvão importado, que, além de possibilitarem maior diversificação para a matriz de geração de energia elétrica brasileira e maior segurança de suprimento, estão sujeitas a uma volatilidade de preço menor se comparadas às usinas a diesel ou a óleo combustível. Entretanto, o carvão mineral é uma fonte muito poluidora.

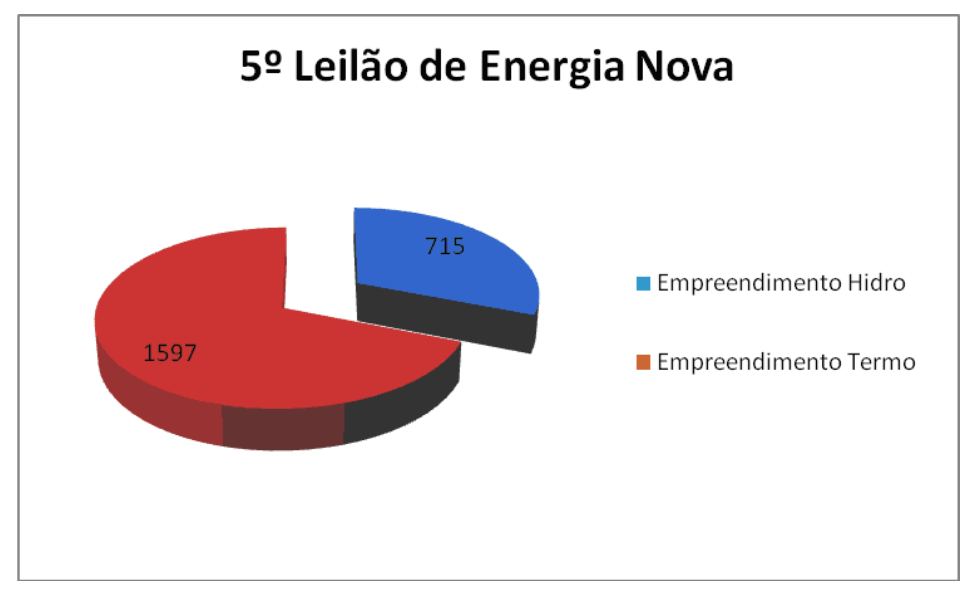


Fig. 2.12 - Quantidade de lotes comercializados no $5^{\circ}$ Leilão de Energia de Compra de Energia Nova

Já em 2008, foram realizados o sexto e sétimo leilões para dar continuidade aos novos empreendimentos para os anos de 2011 e 2013, respectivamente.

\subsubsection{Sexto e Sétimo Leilões de Energia Nova}

No meio de setembro de 2008 foi realizado o sexto leilão (A-3) de geração a partir de novos empreendimentos. Não houve participação de usinas hidrelétricas no certame. Ao final, foram contratados 1.076 MW médios. De ponto de vista de segurança de abastecimento, o resultado é positivo, uma vez que possibilitou o atendimento da demanda de 969 MWmed projetada pelas distribuidoras. Novamente os empreendmentos hídricos não foram qualificados, como se evidencia na figura 2.13 .

Nesse leilão se comercializou energia de empreendimentos termelétricos a óleo combustível e a gás natural. A tabela 2.5 compara o sexto e sétimo leilões:

Tabela 2.5 - Sexto Leilão (A-3) - 17.9.2008 e Sétimo Leilão (A-5) - 30.9.2008 (MW Médios)

\begin{tabular}{|c|c|c|c|c|c|c|}
\hline \multirow{2}{*}{$\begin{array}{l}\text { Entrada em } \\
\text { Operação }\end{array}$} & \multicolumn{3}{|c|}{$\begin{array}{c}\text { Sexto Leilão (A-3): } \\
17.9 .2008\end{array}$} & \multicolumn{3}{|c|}{$\begin{array}{c}\text { Sétimo Leilão (A-5): } \\
30.9 .2008\end{array}$} \\
\hline & \multicolumn{3}{|c|}{2011} & \multicolumn{3}{|c|}{2013} \\
\hline & Hídrica & Térmica & Total & Hídrica & Térmica & Total \\
\hline \multirow{3}{*}{$\begin{array}{l}\text { Lotes vendidos } \\
\text { Garantia Física } \\
\text { Energia para ACL }\end{array}$} & 0 & 1076 & 1076 & 121 & 3004 & 3125 \\
\hline & * & ${ }^{*}$ & * & * & * & * \\
\hline & * & * & * & * & * & * \\
\hline
\end{tabular}

Fonte: BNDES Setorial - Leilão de Energia Nova - Análise e Sistemática de Resultados 2008

* Nota: Dados ainda não disponíveis pela CCEE

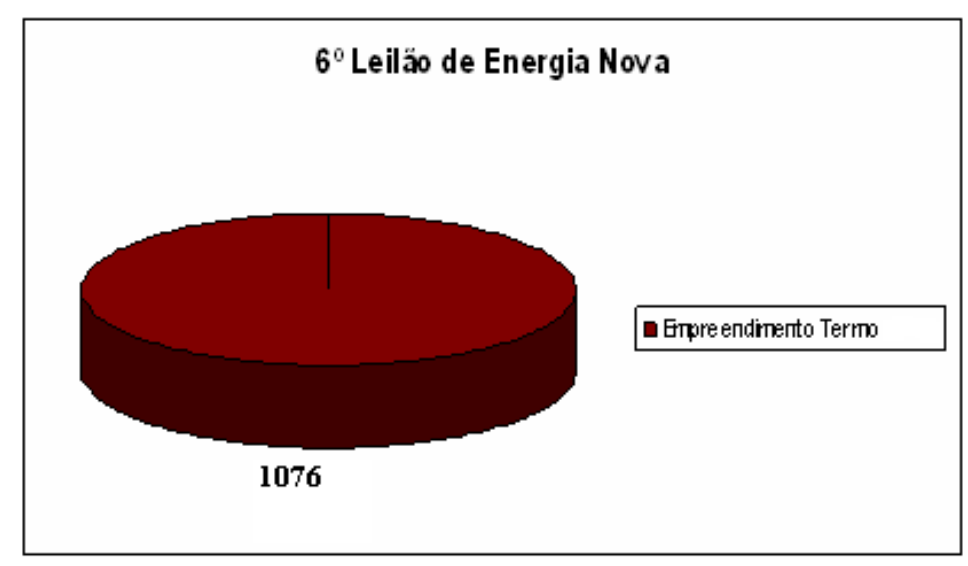

Fig. 2.13 - Quantidade de lotes comercializados no $6^{\circ}$ Leilão de Energia de Compra de Energia Nova 
O sétimo leilão de energia nova (A-5) para entrega de energia a partir de 2013 foi realizado no fim de setermbro de 2008. O leilão contou com a participação de 51 usinas ofertando 8.535 MW médios e resultou na negociação de 3.125 MW médios provenientes de 24 empreendimentos, dessa enegia contratada 2969 MW médios foram para empreendimentos térmicos e 156 MW médios para hídricos.

Segundo a Análise Pós $7^{\circ}$ Leilão do Instituo Acende Brasil, tem-se que a exemplo dos últimos leilões de geração, o atendimento da demanda projetada se deu predominantemente a partir da energia de empreendimentos térmicos, com destaque para o óleo combustível. Todavia, outras matrizes também participaram como o gás natural liquefeito, o carvão e o bagaço de cana que apesar de ser incipiente já pode ser considerado um recurso alternartivo para estudos. Semelhante a outros leilões, nesse a predominância térmica irá deixar a matriz energética 'mais suja' uma vez que leilões A-5 servem para contratação de energia de base para a expansão, isto é, deveria haver predominância hídrica com ajustes futuros, em leilões A-3, de empreendimentos térmicos.

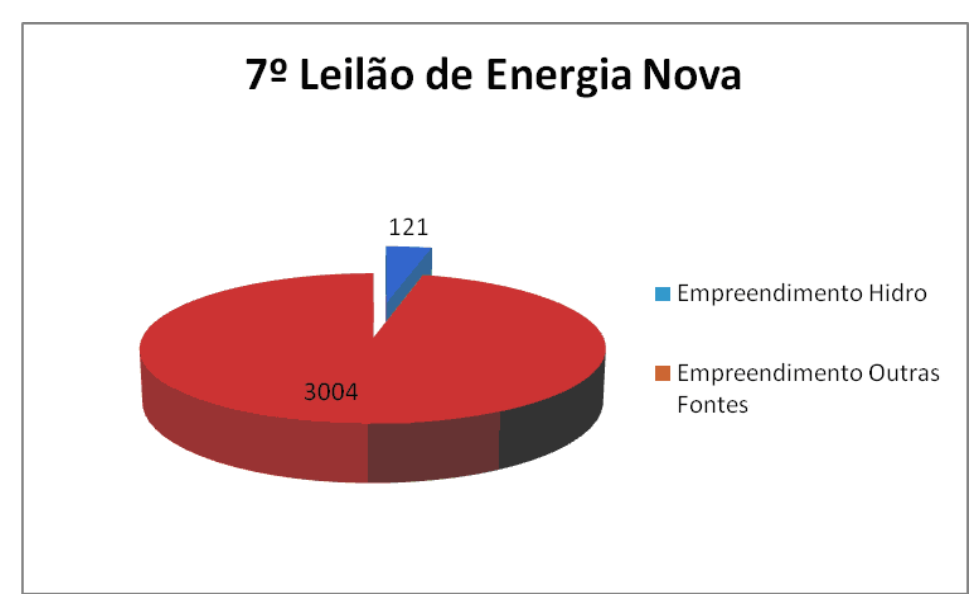

Fig. 2.14 - Quantidade de lotes comercializados no $7^{\circ}$ Leilão de Energia de Compra de Energia Nova

\subsubsection{Apreciação Global dos Leilões de Energia}

Desses Leilões de Energia Nova realizados tem-se seguinte resumo de energia contratada, conforme a figura 2.15 : 


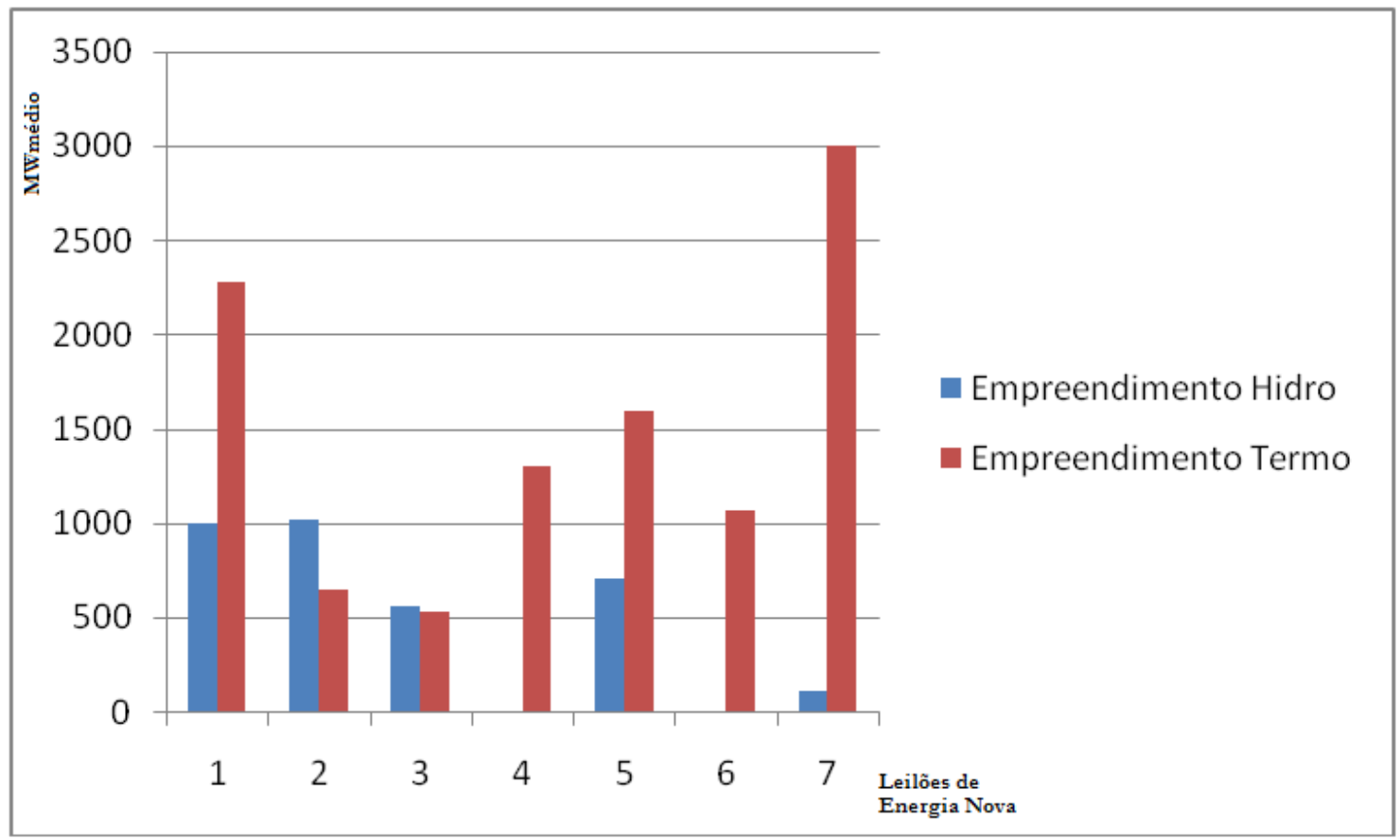

Fig. 2.15 - Energia Contratada em MW médios ao longo dos Leilões

A evolução do volume de energia contratada (MW médio) com início de geração entre o período de 2008 a 2013 (ao longo dos 7 leilões) segue na figura 2.16, nessa análise desconsiderou-se os leilões de energia de fonte alternativa:

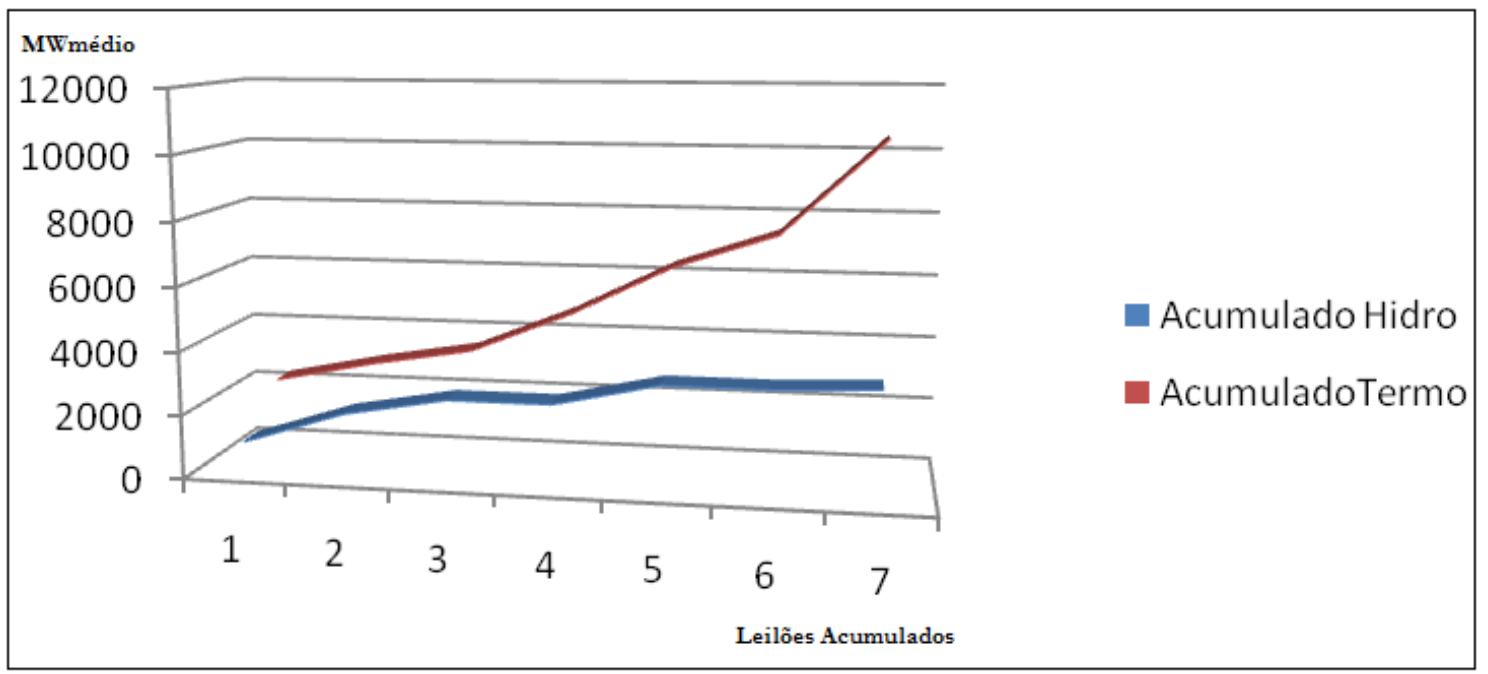

Fig. 2.16 - Evolução da Energia Contratada em MW médio ao longo dos Leilões

Na figura acima se vê que a expansão de Energia Nova se dá por meio da matriz térmica, sendo esta cada vez mais presente em relação aos recursos hídricos.

A figura 2.17 apresenta a oferta adicional de energia até 2012, no qual são mostradas a quantidade de lotes vendidos, a garantia física que entrará no sistema elétrico e a participação da 
geração termelétrica em termos de garantia física. Há uma crescente oferta de lotes para atender à demanda prevista pelas distribuidoras até 2010.

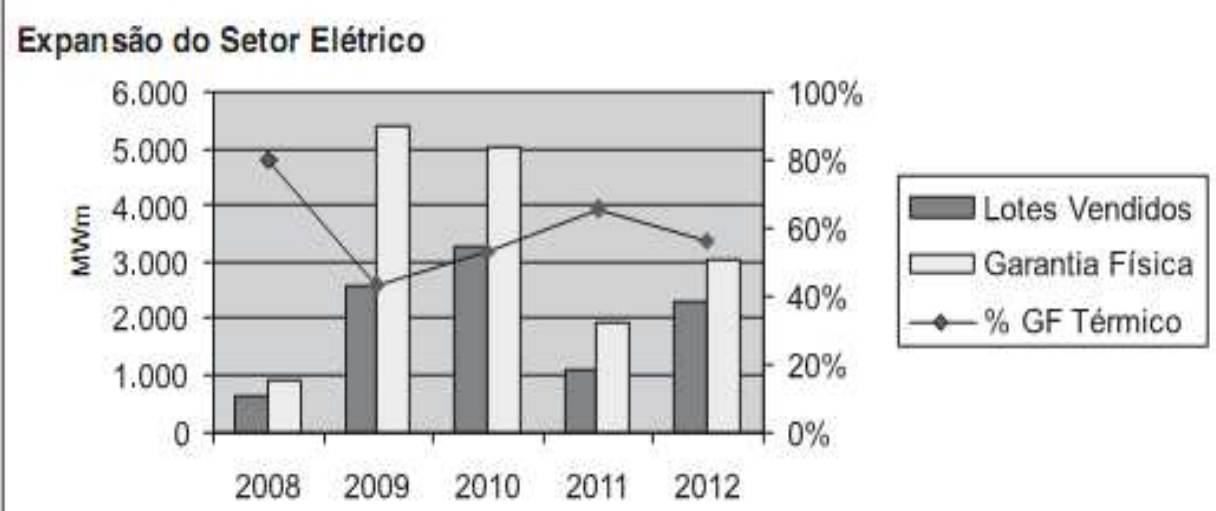

Fig. 2.17 - Expansão do Setor Elétrico em termos térmicos e hídricos para os cinco primeiros leilões

Fonte: BNDES Setorial - Leilão de Energia Nova - Análise e Sistemática de Resultados 2008

A análise a que se chega é que há uma diferença expressiva entre garantia física e lotes vendidos, principalmente em 2009 e 2010, revelando a expectativa dos geradores de aumento de preços da energia elétrica, período durante o qual não se pode contar com a energia de usinas que ainda não iniciaram a etapa de construção.

Nos leilões de projetos térmicos, tem-se o ICB (Índice de Custo Benefício) que é um índice utilizado para a ordenação econômica de empreendimentos de geração termelétrica, diferentemente dos empreendimentos hídricos, os quais são leiloados em função da tarifa de energia elétrica. Resumidamente, ele reflete o preço da energia térmica. $\mathrm{O}$ exame detalhado sobre ICB e os parâmetros que entram em sua composição e seu cálculo são estudados no capítulo 4.

A valoração agregada ao ICB e à tarifação de energia elétrica (empreendimentos hídricos) pode ser dimensionada, respectivamente, nas figuras 2.18 e 2.19. Uma observação a ser feita é que na figura que relaciona o preço da tarifação energética hidráulica ao longo dos leilões não faz menção ao valor de energia do quarto e do sexto leilões, visto que não houve contratação hidráulica nos mesmos como foi demonstrado anteriormente. 


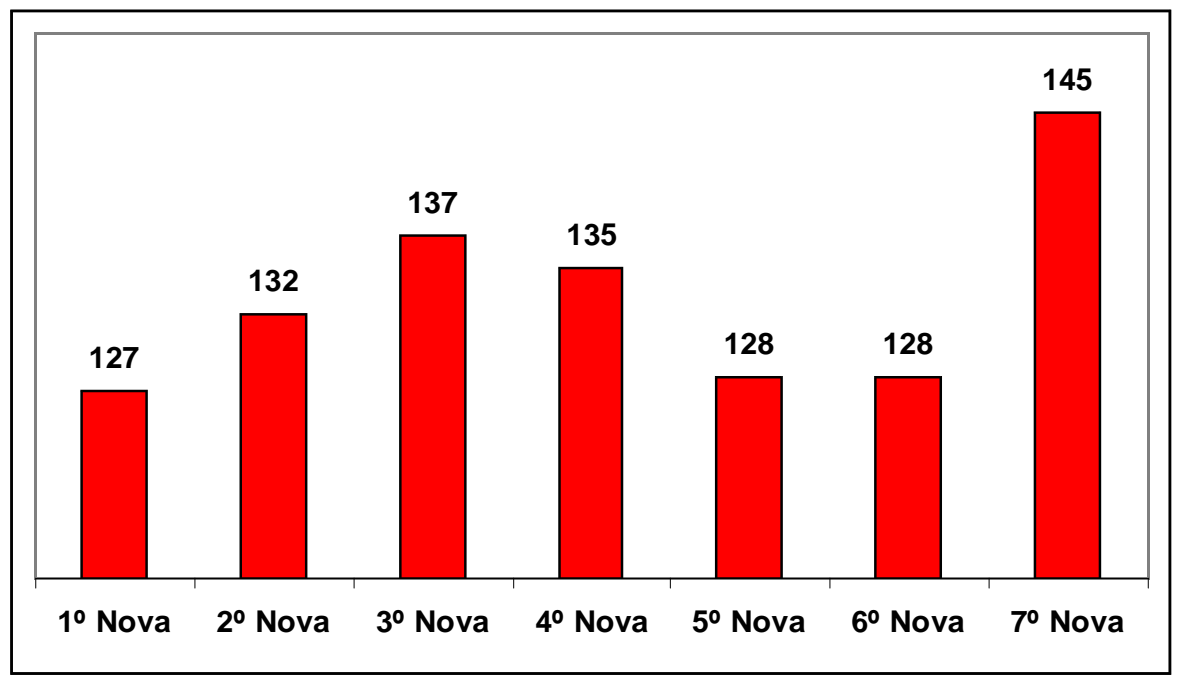

Fig. 2.18 - Preço da Energia Térmica nos leilões (ICB - R\$/MWh)

Fonte: Instituto Acende Brasil - Análise Pós Leilão com dados da CCEE, 2008

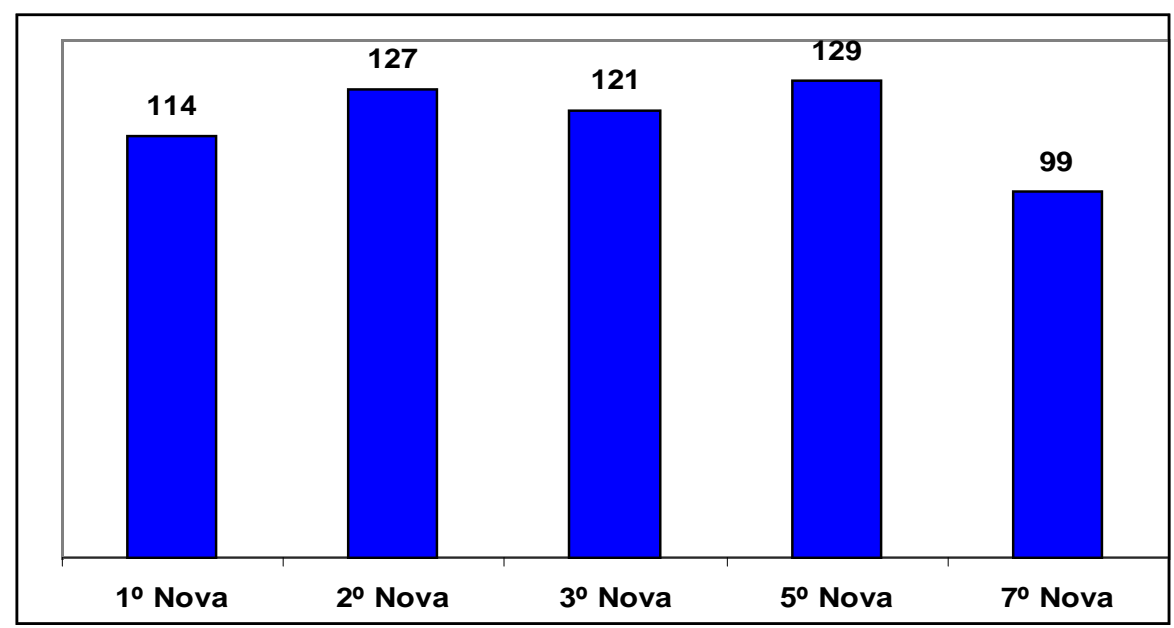

Figura 2.19 - Preço da Energia Hidrelétrica nos leilões (R\$/MWh)

Fonte: Instituto Acende Brasil - Análise Pós Leilão com dados da CCEE, 2008

Observa-se que o preço médio da energia oriunda das termelétricas ao longo dos leilões sofreu variações que dependem da coerência com os custos marginais da tecnologia da geração empregada, do retorno do capital investido incluindo as receitas geradas para $\mathrm{o}$ empreendimento. $\mathrm{O}$ valor máximo do ICB ocorreu no último leilão ( $7^{\circ}$ Leilão de Energia Nova) ao preço médio de R \$145 / MWh, significativamente superior aos outros preços. Explicações do mercado para este fato é a elevação do custo de capital e do combustível e os sinais de encarecimento do crédito em decorrência da atual crise financeira global. Os preços da energia hidrelétrica são, no geral, menores que os térmicos visto que não possuem custos operacionais tão altos associados quanto aos empreendimentos térmicos. 
O custo esperado da geração térmica é superior ao das tarifas de energia hidráulica, pois, em geral, os projetos térmicos têm menor investimento de capital, maior custo operacional e menor ganho de escala, não desconsiderando também o fato de os contratos de comercialização de energia dos projetos térmicos serem de 15 anos, enquanto os contratos dos projetos hídricos são de 30 anos.

A evolução dos Leilões de Energia Nova expressa uma nova temática dada à matriz brasileira com um forte impacto sobre geração hídrica, reforçando o papel da complementaridade dos recursos energéticos. Nesse sentido, os empreendimentos térmicos norteiam, até agora, a expansão da contratação de energia. Outro aspecto importante é que fontes ligadas ao petróleo, como óleo combustível e óleo diesel, estão sujeitas à pressão constante das variações cambiais. Portanto, é possível o aproveitamento do grande potencial hídrico brasileiro ser retomado, refletindo seu impacto nos próximos leilões.

Com o cenário dos leilões definido, é possível estabelecer o enquadramento do gás natural, além das outras matrizes verificadas nos empreendimentos termelétricos.

\subsection{Gás Natural nos Leilões de Energia Nova}

Conforme a evolução dos leilões de energia nova, o que foi constatado até o sétimo leilão foi as variações das fontes energéticas, mas sempre se orientando para a termeletricidade. A análise que pode ser feita é de como avaliar o "vetor de desenvolvimento" da energia brasileira. Pode-se indagar sobre a composição da nossa matriz, como se estrutura a nossa oferta de capacidade geradora para o futuro ou ainda o impacto de fontes renováveis ou nãorenováveis. Com isso, é possível realizar uma análise geral da inserção do gás natural dentro das termelétricas ao longo dos leilões.

No primeiro leilão de energia nova, sua caracterização térmica foi eminentemente a base de gás natural representando cerca de 61\% (1390 MW médio) da parte térmica do leilão. Ou seja, com base no início da expansão da geração brasileira, o papel do gás natural apresentava-se como um indício de uma fonte extremamente competitiva em relação às demais fontes. Todavia, conforme mostra a figura 2.20-b, no segundo leilão a sua participação limitouse a apenas 2\% (10 MW médio). Esta baixa participação deve-se às restrições antevistas à oferta futura de gás natural, o que impediu a obtenção de garantias de fornecimento do combustível e abriu espaço para usinas a óleo combustível e a diesel, que tiveram suas participações elevadas de $1 \%$ e $4 \%$, respectivamente, no $1^{\circ}$ leilão, para $44 \%$ e $43 \%$, no segundo. Cabe ressaltar, ainda, a ausência de participação das usinas termelétricas a carvão, que tiveram um percentual de $24 \%$ 
de participação no $1^{\circ}$ leilão, mas sequer foram habilitadas para o segundo. As usinas termelétricas a biomassa (bagaço de cana), por sua vez, mantiveram sua participação discreta no resultado em torno de $11 \%$, como se evidencia na figura 2.20-b.

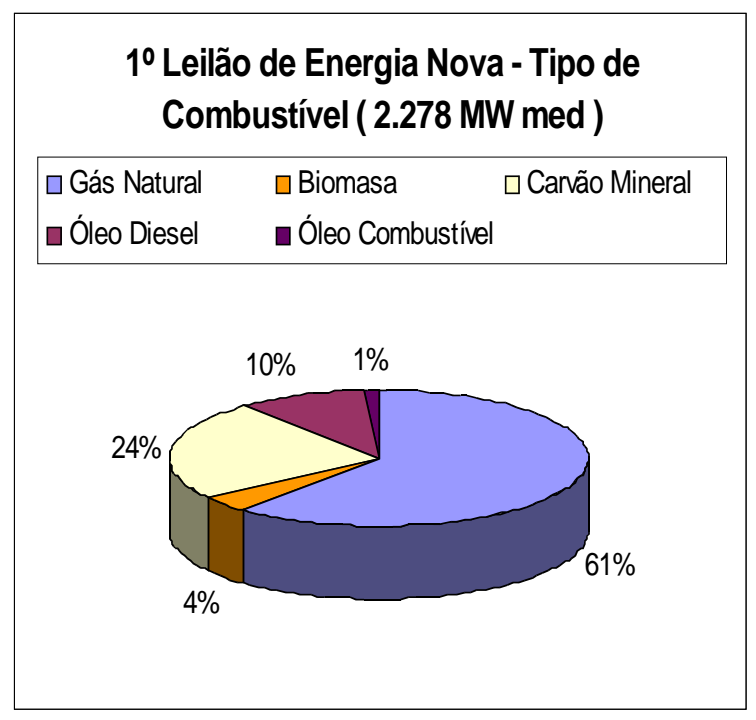

(a)

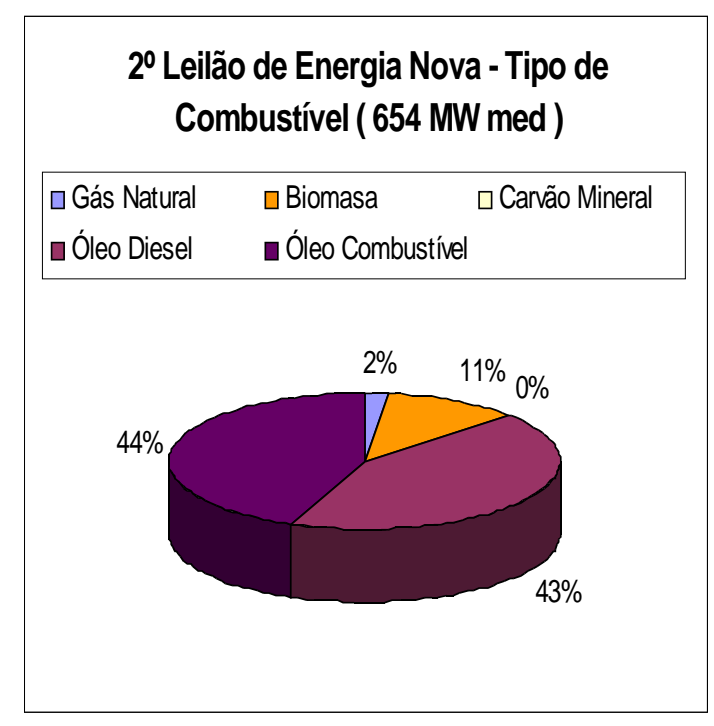

(b)

Fig. 2.20 - Resultado do Tipo de Combustível do $1 .^{\circ}$ e $2 .^{\circ}$ Leilóes de Energia Nova

Fonte: CCEE e Duke Energy Brasil, 2006

No terceiro leilão terceiro de energia nova, houve a volta significativa da fonte térmica do gás natural dominante com 38\% (203 MW médios) representado no forte investimento da Petrobrás, por meio da usina Termomacaé, outros 37\% de uma usina a gás de processo da Companhia Siderúrgica do Atlântico, da THYSSENKRUPP CSA, 13\% de térmicas a óleo diesel, $11 \%$ de térmicas a biomassa e apenas $1 \%$ de usinas a óleo combustível. Ressalta-se que o gás de processo provém do aproveitamento dessas fontes para geração elétrica ocorre, em geral, como uma destinação útil de subprodutos ou rejeitos de processos produtivos, representando um ganho de eficiência e/ou uma forma de evitar a emissão de efluentes nocivos ao meio ambiente.

No quarto leilão foi demonstrado que apenas as usinas a óleo combustível venderam energia. Em função do baixo preço-teto fixado para a geração hidrelétrica, não foram sequer oferecidos lances durante a realização do certame desta tecnologia. No certame de termelétricas, o preço-teto inibiu o interesse dos empreendimentos térmicos a gás natural que decidiram não participar em função do impasse sobre as elevadas multas impostas pela ANEEL às usinas a gás que não cumpriram os contratos de fornecimento de energia celebrados em face de um possível cenário de falta de gás. A figura 2.21 estabelece a visão dos combustíveis dos dois leilões. 


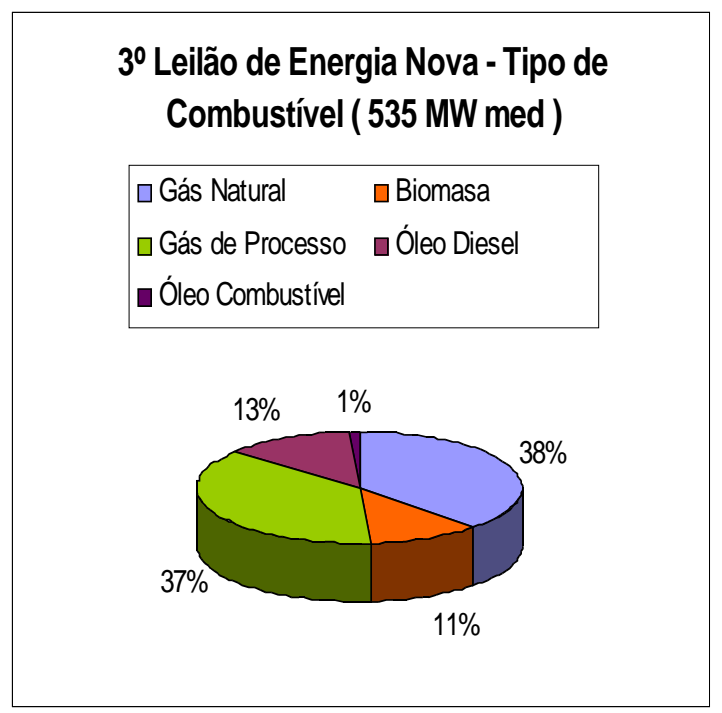

(a)

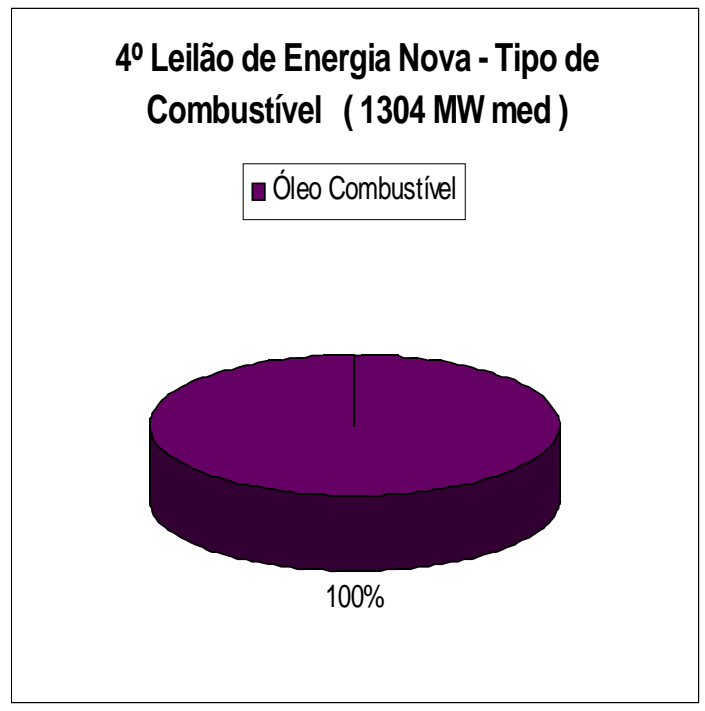

(b)

Fig. 2.21 - Resultado do Tipo de Combustível do $3 .^{\circ}$ e $4^{\circ}$ Leilóes de Energia Nova

Fonte: CCEE e Duke Energy Brasil 2007

No quinto leilão foi demonstrada (figura 2.22-a), dentro das usinas térmicas, uma volta de outros empreendimentos das fontes carvão mineral e gás natural liquefeito diminuindo o impacto do óleo combustível advindo do leilão anterior. Nesse leilão, no cenário do gás natural, representa-se em um importante progresso relacionado ao gás natural liquefeito (GNL) que pela primeira vez aparece nos leilões de energia nova - sua estrutura e cadeia serão estudadas no capítulo seguinte. Foi constatada cerca de 22\% (373 MW médios) da energia contratada referente ao GNL da parte térmica. O GNL ilustra a operação de flexibilizar a demanda e garantir o abastecimento do gás natural, não pode ser encarado como suprimento definitivo do gás natural. Segundo a Empresa de Consultoria Gas Energy, "o gás natural liquefeito não é a salvação do fornecimento do gás natural no Brasil", ele representa um elo para o aumento da entrada do volume maior da produção interna de gás natural. Já os dados do sexto leilão (figura 2.22-b) refletem a matriz com a representatividade do óleo combustível em sua maioria, mas o gás natural contribuiu com a feição de 25\% (269 MW médios) da parte térmica. 


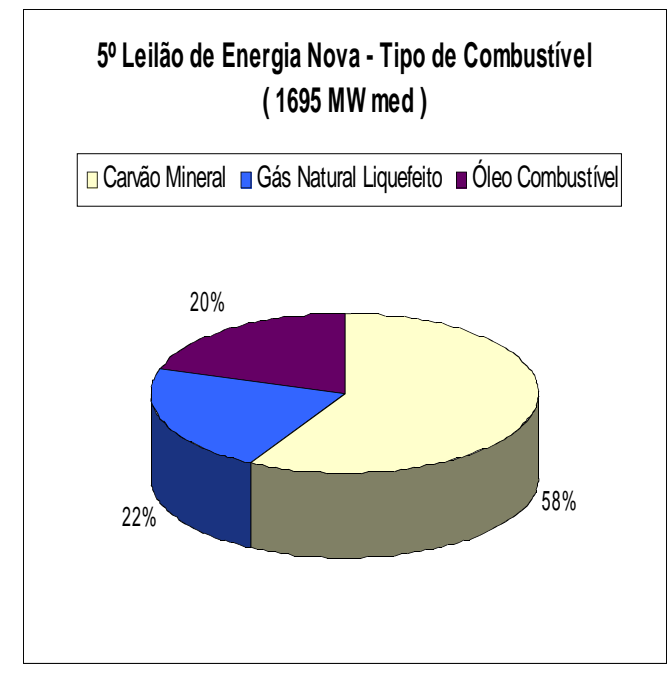

(a) $6^{\circ}$ Leilão de Energia Nova - Tipo de Combustível

(1076 MW med)

—Óleo Combustível ı Gás Natural

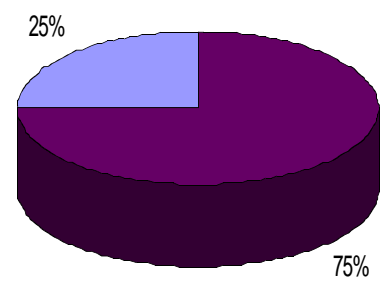

Fig. 2.22 - Resultado do Tipo de Combustível do $5 .^{\circ}$ e $6 .^{\circ}$ Leilóes de Energia Nova

Fonte: Instituto Acende Brasil 2008

No último leilão em estudo, o sétimo leilão de energia nova, a efetividade do gás natural reflete-se novamente no GNL com 23\% (683 MW médios) dos empreendimentos térmicos do leilão. O gás natural liquefeito, como pode ser visto nesse leilão e no quinto, concebe uma garantia para o mercado, visto que ainda não há uma competitividade bem estabelecida no seu panorama - seu preço ainda é superior que o gás natural produzido nacionalmente ou importado da Bolívia. Entretanto, não se descarta, num futuro próximo, a possibilidade dele se tornar um combustível de destaque inserido no mercado das termelétricas, como mostra a figura 2.23 .

\section{Leilão de Energia Nova - Tipo de Combustível ( $3004 \mathrm{MW}$ med )}

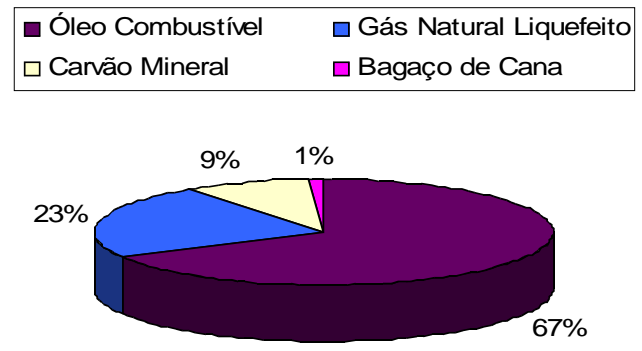

Fig. 2.23 - Resultado do Tipo de Combustível do $7^{\circ}$ Leilão de Energia Nova

Fonte: Instituto Acende Brasil 2008 
A figura 2.24 avalia o impacto do gás natural no retrospecto dos leilões, em comparação com os outros empreendimentos térmicos e hídricos. Nessa análise, considera-se o GNL e o Gás Natural juntos contabilizados. Nota-se, imediatamente, a constância do gás natural no certame dos leilões não participando, somente, do quarto leilão. Logo, o mesmo insumo representa a fonte térmica de maior frequiência, em relação a outras (óleo diesel, carvão, óleo combustível, biomassa, etc.). Esse fato revela que o gás natural já possui uma tecnologia madura no cenário brasileiro e já confiável, principalmente pelos investimentos brasileiros em exploração, infraestrutura e transporte, além é claro da razoabilidade dos custos de combustível e sua independência do petróleo.

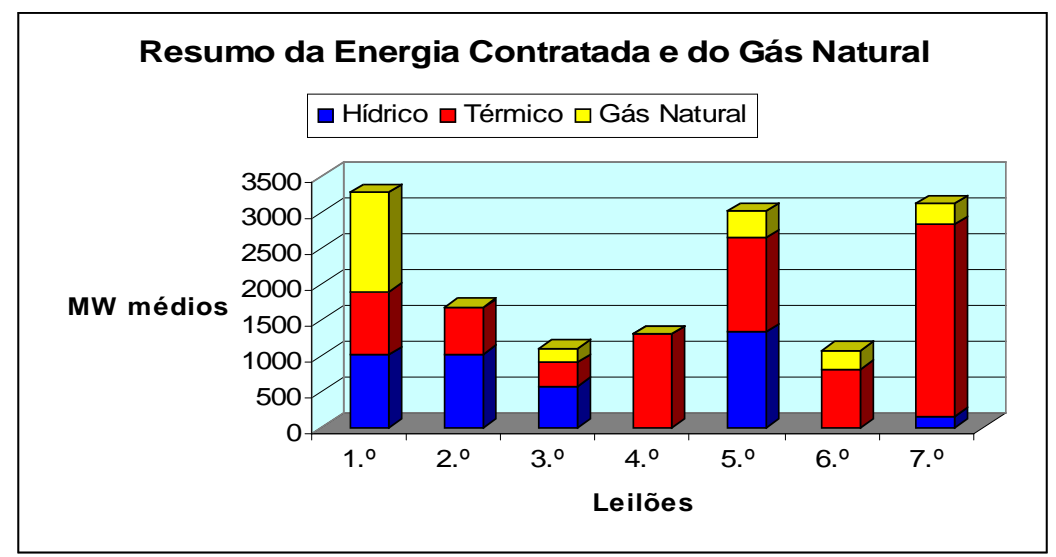

Fig. 2.24 - Gás Natural nos Leilões de Energia Nova

Outra ponderação para se visualizar justamente a expansão do setor energético da geração brasileira está em comparar ao longo da energia contratada para os anos futuros, caracterizada nos próprios leilões. Nessa visão geral, ratifica-se a importância do gás natural dentro da viabilidade térmica de combustíveis, considerando sua presença ao longo dos anos de expansão na figura 2.25 .

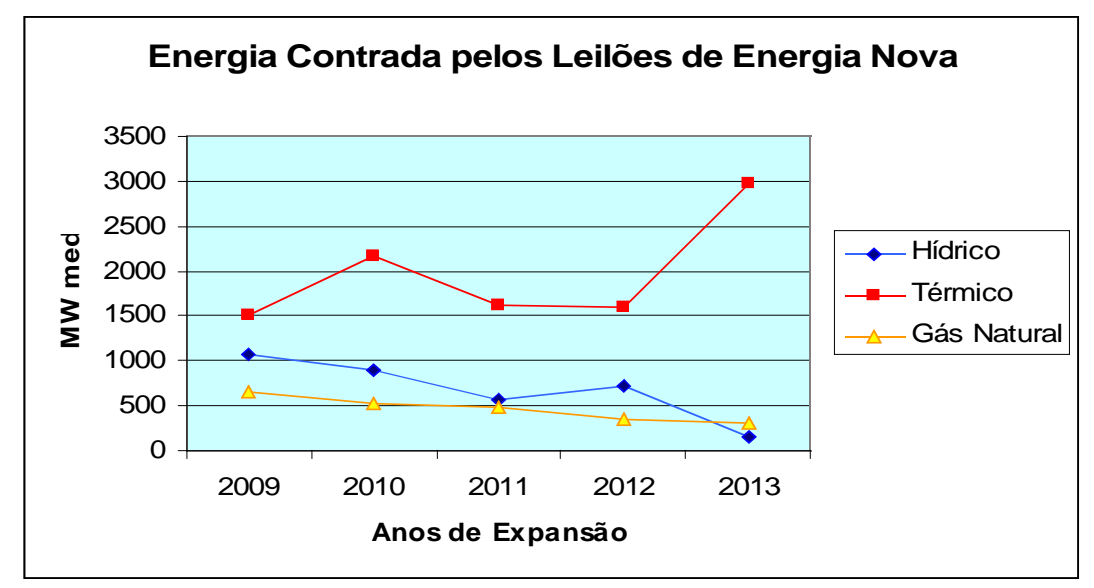

Fig. 2.25 - Gás Natural ao longo dos Anos de Expansão 


\subsubsection{Energia Térmica e o Gás Natural nos Submercados}

O Sistema Interligado Nacional (SIN) é formado pelos subsistemas Sul, Sudeste/CentroOeste, Nordeste e parte da região Norte. Segundo o ONS, o tamanho e características dessa interligação permitem considerá-lo único em âmbito mundial. O sistema de produção e transmissão de energia elétrica do Brasil é um sistema hidrotérmico. Apenas 3,4\% da capacidade instalada de produção de eletricidade do país encontram-se fora do SIN, em pequenos sistemas isolados localizados principalmente na região amazônica.

O panorama geral dos resultados dos leilões de energia nova resulta na participação das fontes térmicas de acordo com a figura 2.26 que estabelece a comparação dos submercados.

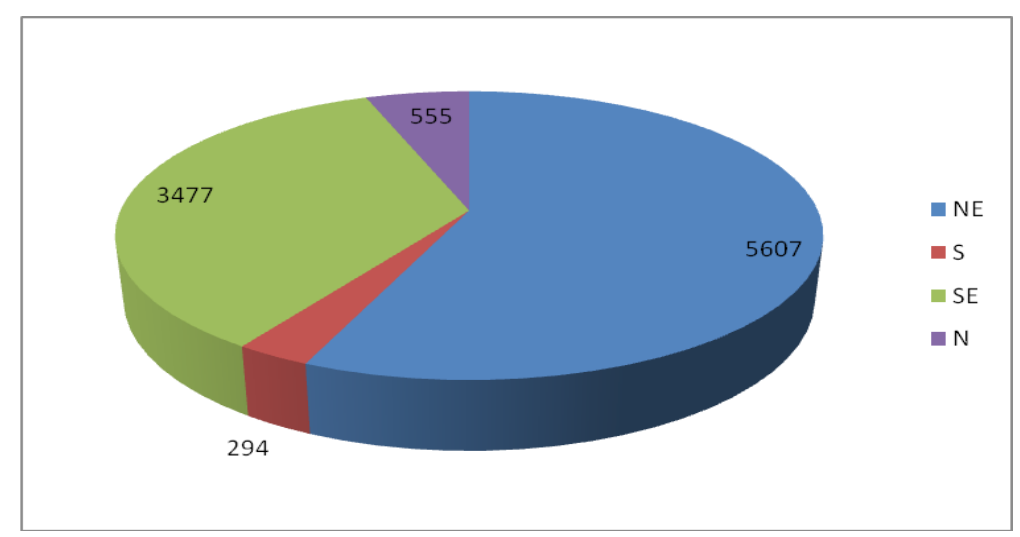

Fig. 2.26 - Participação térmica em MW médios quanto aos submercados

Os dados fornecidos do leilão demonstram a grande participação dos submercados térmicos do Nordeste e do Sudeste na contratação de energia térmica. Esses dados concebem duas funções distintas para ambas as regiões. No Nordeste, a termeletricidade, em geral, é utilizada como forma de suprimento da escassez hídrica característica dessa região. No Sudeste, além desse ponto de vista, há principalmente a complementaridade energética pela intensa demanda de energia dessa região para evitar um desabastecimento, baseando-se nisso estabelece-se decisões do acionamento de usinas térmicas.

O Projeto Malhas, modelagem de negócio proposta pela Petrobras para a expansão do sistema de transporte de gás natural atualmente operado pela Transpetro, tem como objetivo permitir a ampliação das malhas de gasodutos do Nordeste e do Sudeste do País para atender ao Programa Prioritário de Termeletricidade (PPT), uma vez que coube à Petrobras, por decisão de Governo, garantir o suprimento de gás natural para as usinas inseridas no Programa, por prazo de até 20 anos. 
O gás natural inserido nesses submercados apresenta sua representatividade, proporcional às usinas térmicas, ou seja, ocupando o Nordeste e o Sudeste brasileiro. A tabela 2.6 mostra a capacidade instalada e o número de empreendimentos das usinas que funcionam a gás natural para cada região.

Tabela 2.6 - Capacidade Instalada ( $k$ W)

\begin{tabular}{|l|c|c|c|c|c|c|}
\cline { 2 - 8 } \multicolumn{1}{c|}{} & \multicolumn{3}{c|}{ Em Operação } & \multicolumn{2}{c|}{ Em Construção } & \multicolumn{2}{c|}{ Em outorga } \\
\hline \multicolumn{1}{c|}{ Submercados } & № & Capacidade & № & Capacidade & № & Capacidade \\
\hline $\begin{array}{l}\text { Sudeste/Centro- } \\
\text { Oeste }\end{array}$ & 41 & 6.078 .755 & 2 & 18.402 & 21 & 5.816 .138 \\
\hline Nordeste & 22 & 2.156 .700 & 2 & 352.656 & 5 & 524.138 \\
\hline Sul & 7 & 2.425 .158 & 2 & 7.000 & 2 & 7.600 \\
\hline Norte & 1 & 349.950 & - & - & - & - \\
\hline
\end{tabular}

Fonte: Plano Nacional de Energia - Gás Natural 2007

A tabela ilustra o fato que o Sul possui a segunda maior capacidade instalada, todavia o número de usinas térmicas é reduzido. A expansão energética nessa região ficou prejudicada pela interrupção da importação do gás natural da Argentina. O Norte possui um potencial instalado inferior aos demais, todavia, em termos de reservas de gás natural onshore, destacamse as reservas localizadas em Urucu (AM), região de difícil acesso no interior da floresta Amazônica. Praticamente todo o gás natural produzido nos campos de Urucu é reinjetado nos poços de produção de petróleo dadas estas dificuldades. Basicamente, projeta-se escoar esta produção através de dois gasodutos: um ligando Urucu a Porto Velho (RO) e outro ligando Coari (AM) a Manaus (AM), para atender à demanda de energia na região Norte do país. Esse projeto de expansão pode realizar mudanças de abastecimento, incluindo a transição de usinas movidas a óleo para gás natural, caso se verifique a atratividade comercial.

Os leilões e a capacidade instalada nos submercados reforçam a expansão do gás natural no Nordeste e no Sudeste. Isso é mais evidente ainda no plano governamental da integração da malha dos gasodutos dessas regiões, formando o GASENE. Essa é a tentativa da formação de uma rede básica de transporte permitindo a otimização da produção e movimentação do país, é uma "rede neural" que alia os dois principais submercados brasileiros do gás natural, consolidando o abastecimento de termelétricas em ambas as regiões. 


\section{ANÁLISE DA EXPANSÃO POR MEIO DO USO DO GÁS NATURAL}

\subsection{Matrizes Energéticas}

Nos últimos anos a diversificação da matriz elétrica tem sido vista como um fator de aumento da segurança no abastecimento. Assim sendo, nos estudos da expansão do parque de geração elétrica brasileiro, há que se analisar a disponibilidade de todos os recursos energéticos com potencial de atender a crescente demanda de energia elétrica da população a preços que possam garantir a modicidade tarifaria. É importante também comparar as matrizes energéticas diferenciando-as nas questões ambientais.

\section{Carvão mineral}

Segundo o International Energy Outlook 2005 (EIA/DOE, 2005), o carvão mineral é o combustível fóssil com a maior disponibilidade no mundo.

A opção pelo carvão se deve, em grande parte, a estabilidade dos seus preços, que aumenta a segurança no atendimento à demanda da população. Os preços do mineral na década de 1990 eram decrescentes, por conta, principalmente, da expansão do uso do gás natural. Atualmente, mesmo com o aumento do preço do petróleo e do gás natural, não há uma variação significativa. O preço do carvão nacional vem caindo desde 1988. O preço passou de US\$ 76/t para US\$35/t em 2004.

Por causa da inexistência de mercados de commodities internacionais de carvão mineral, não há muitas referências quanto a projeções de seus preços. As poucas que existem não projetam grandes variações nos preço do combustível. Na figura 3.1, vemos que a variação do preço internacional do carvão é menor que a do preço do petróleo e do gás natural. 


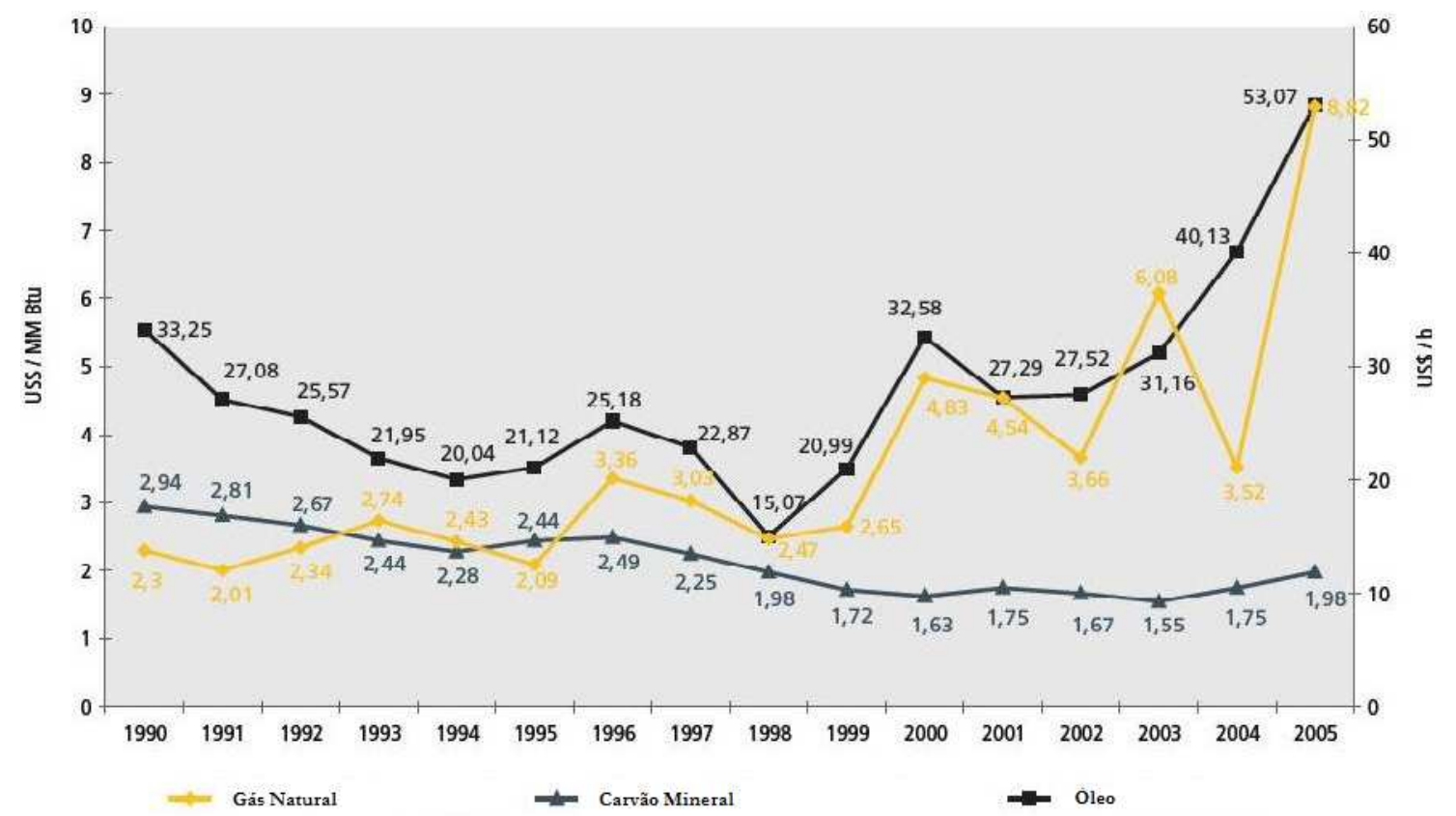

Fig. 3.1 - Preços internacionais do Petróleo, Gás Natural e Carvão

Fonte: Country Watch Forecast

Os preços de exportação de carvão começaram a aumentar no final de 2003 e continuaram a escalada em 2004, o que pode ser explicado pela limitada capacidade de exportação verificada naquele período. A elevação de preços de exportação e de fretes contribuiu para a elevação geral dos preços do carvão e do coque.

Os dados apresentados e as projeções sugerem que o preço do carvão no mundo é afetado apenas marginalmente pela variação dos preços do petróleo e do gás natural. O principal impacto é indireto, que diz respeito ao aumento dos custos de transporte.

Considerando que as termelétricas a carvão nacional devem se localizar na "boca da mina" ou próximas a elas, a questão de infra-estrutura de transporte não se mostra uma restrição relevante à expansão da geração a carvão. Mas para a expansão do consumo de carvão mineral são necessários grandes investimentos em infra-estrutura nas jazidas ainda não exploradas, ou a importação o produto para tal finalidade.

Com a crescente pressão ambiental, especialmente em relação às mudanças climáticas, o fator tecnológico assume papel relevante na oferta de energia, ambiente no qual se insere a expansão da geração termelétrica a carvão mineral. Neste caso, isto decorre do fato de que, além do tratamento caro e complexo do carvão mineral para sua utilização, também sua combustão emite gases acidificantes como óxidos de nitrogênio e de enxofre, além de dióxido de carbono e material particulado. Outra questão relevante, é que, dentre as termelétricas, as usinas a carvão são as que produzem maior quantidade de resíduos sólidos. 
óleo

Baseado ainda na figura 3.1, tem-se que o preço internacional do petróleo tende a valores crescentes de forma exponencial. Isso certamente não é bom para a produção de energia elétrica por meio da utilização desse combustível, pois, como será visto mais adiante, o preço é um fator altamente relevante na formulação final do preço final da energia elétrica. Mais ainda as oscilações nas cotações dos produtos de base (commodities), como é o caso do petróleo, têm impacto significativo nos fluxos financeiros mundiais, por isso o atual momento econômico mundial não favorece sua utilização.

Do ponto de vista ambiental, desde a pesquisa de jazidas de petróleo, que pode afetar ecossistemas marinhos, até a comercialização de derivados, que pode trazer impacto ao solo e aos aqüíferos, a operação dos diversos setores da indústria de petróleo, bem como o maciço consumo de seus produtos, exige atenção constante de instituições responsáveis pelo controle ambiental das atividades econômicas.

A queima de combustíveis com altos teores de enxofre, além de gerar óxidos de enxofre, prejudica a ação de catalisadores de conversão de gases poluentes em substâncias nocivas, instalados nos escapamentos. Na matriz energética, a principal representação está nos combustíveis a óleo diesel e a óleo combustível.

- Óleo Diesel: é considerado poluente atmosférico, na medida em que os produtos da combustão, basicamente gás carbônico acompanhado de outros compostos nocivos, são expelidos para o ambiente, em alguns casos, na forma de fumaça negra. As regulamentações ambientais no Brasil, assim como em outros países, por meio das suas agências reguladoras, estabelecem limites para a composição dos gases de combustão, segundo padrões que definem valores cada vez menores ao longo dos anos futuros, para que os fabricantes introduzam inovações de desenvolvimento tecnológico capazes de assegurarem a redução dos níveis atuais de poluição ambiental.

- Óleo Combustível: representa frações residuais mais leves do petróelo, sua diferenciação é feita pelo teor de enxofre apresentado (no óleo diesel o teor de enxofre é mais leve), é um grande poluidor atmosférico visto que os gases sulforosos produzem acidez da atmosfera em sua combustão. Ele guarda características de todo derivado do petróleo como a emissão de gases 
carbônicos que contribuem para o efeito estufa, consequentemente para o aquecimento global.

\section{Biomassa}

A biomassa é a matéria orgânica utilizada na produção de energia. Nem toda a produção primária do planeta passa a incrementar a biomassa vegetal, pois parte dessa energia acumulada é empregada pelo ecossistema na sua própria manutenção. Ela é vantajosa em relação aos combustíveis derivados do petróleo e o carvão mineral quanto a impactos ambientais. As biomassas mais utilizadas são: a lenha, o bagaço da cana-de-açúcar, galhos e folhas de árvores, papéis, papelão, etc. A biomassa é o elemento principal de diversos novos tipos de combustíveis, tais como as novas fontes energéticas: o bio-óleo, o biogás e biodiesel.

A queima da biomassa ou de seus derivados provoca a liberação de gás carbônico na atmosfera. As plantas, através da fotossíntese, transformam esse gás carbônico nos hidratos de carbono, liberando oxigênio. Assim, a utilização da biomassa, desde que não seja de forma predatória, não altera a composição da atmosfera.

A utilização de biomassa como combustível traz a vantagem de seu poder energético, todavia é importante ressaltar que se deve ter um amplo controle sobre as áreas desmatadas. Um exemplo disso foi a expansão da indústria de álcool no Brasil e da produção da biomassa a partir do bagaço de cana, onde áreas da região Nordeste, Sudeste e outras foram desmatadas para dar lugar a plantações de cana-de-açúcar. Por isso a preocupação ambiental, mais do que nunca, deve ser prioridade na utilização da biomassa.

\section{Gás Natural}

Conforme sinalizações de produtores no Brasil, os novos preços deverão convergir para os níveis internacionais, que representam os custos marginais de suprimento do país, contribuindo também, para isto, uma tendência mundial de "commoditização" do gás natural.

São inúmeros os ganhos econômicos obtidos pela escolha do gás natural como combustível, mas a principal vantagem é a preservação do meio ambiente. O gás natural é um combustível menos poluente em relação aos outros inseridos na termeletricidade. Sua combustão é limpa, isenta de fuligem e outros materiais que possam prejudicar o meio ambiente. Geralmente apresenta baixos teores de contaminantes como o nitrogênio, dióxido de carbono, água e compostos de enxofre. Além desses, temos os seguintes: 
- Combustão limpa: queima completa sem deixar resíduos;

- Baixíssima presença de contaminantes;

- Em casos de vazamento é rapidamente disperso;

- Maior durabilidade dos equipamentos;

- Custos reduzidos;

- Possibilidade de substituir qualquer fonte de energia convencional;

- Produto acabado, pronto para utilização;

- Melhora o rendimento dos equipamentos em relação ao óleo combustível;

- Sistema de dutos barateia o custo do transporte.

A partir da diferenciação das matrizes energéticas, no tocante aos seus impactos ambientais, o gás natural é caracterizado como um norteador da expansão energética brasileira, pois a sociedade pressiona por fontes que busquem boa eficiência e não poluam o meioambiente, desde a emissão de gases nocivos até a eliminação de resíduos.

\subsection{Gás Natural}

O gás natural é um combustível fóssil composto por gases inorgânicos e hidrocarbonetos saturados com pequenas cadeias de carbono, principalmente o metano (CH4), e em menores quantidades o etano e o propano. Pode ser ainda definido como a porção do petróleo que existe na fase gasosa ou em solução no óleo, nas condições de reservatório, e que permanece no estado gasoso nas condições atmosféricas de pressão e temperatura.

O Gás Liquefeito de Petróleo (GLP) é conhecido como gás de cozinha ou gás de botijão e o gás natural como gás encanado, existindo uma grande diferença nas especificações dos dois produtos. Quanto ao teor de líquidos de gás natural contido na especificação do gás natural é geralmente baixo, como se evidencia na sua composição. 
Tabela 3.1 - Composição do Gás Natural no Espírito Santo

\begin{tabular}{|c|c|}
\hline Metano & $91,36 \%$ \\
\hline Etano & $3,66 \%$ \\
\hline Propano & $1,71 \%$ \\
\hline Butano e + pesados & $0,86 \%$ \\
\hline $\mathrm{N}_{2}$ & $2,05 \%$ \\
\hline $\mathrm{O}_{2}$ & $0,01 \%$ \\
\hline $\mathrm{H}_{2} \mathrm{~S}\left(\mathrm{mg} / \mathrm{m}^{3}\right)$ & 0,15 \\
\hline Enxofre Total $\left(\mathrm{mg} / \mathrm{m}^{3}\right)$ & 1,02 \\
\hline Ponto de Orvalho $-\mathrm{PO}\left({ }^{\circ} \mathrm{C}\right)$ & $-62,14$ \\
\hline PCS kj/m & 39.018 \\
\hline Densidade & 0,62 \\
\hline Índice de Wobbe & 49.739 \\
\hline
\end{tabular}

Fonte: Portal BR - Petrobras Distribuidora S.A

Os recursos de gás natural apresentam-se associados - utilizando a tecnologia de exploração de petróleo (Gás associado) - ou não associados aos recursos de petróleo (Gás nãoassociado). A exploração pode ser onshore (em reservas terrestres) ou offshore.

Gás associado: é encontrado em reservatórios petrolíferos, dissolvido no óleo sob a forma de capa de gás. Apesar de o metano ser o seu principal hidrocarboneto, apresenta, também, teores significativos de hidrocarbonetos parafínicos mais pesados.

Gás não-associado: é encontrado em reservatórios gaseíferos, sem estar em contato com quantidades significativas de óleo. Seu principal hidrocarboneto, também, é o metano, porém difere do gás associado por apresentar pequeno teor dos outros hidrocarbonetos parafínicos.

Após ser extraído dos reservatórios, o gás passa por um conjunto de processos. Inicialmente, os hidrocarbonetos que estiverem em estado líquido e as partículas sólidas (produtos de corrosão, pó etc.) são retirados do gás pelos vasos separadores. No caso de haver contaminação por compostos de enxofre, o gás é enviado para Unidades de Dessulfurização, onde essas substâncias são retiradas. Após esses tratamentos, uma parte do gás é utilizada para recuperação do petróleo nos reservatórios e o restante segue para as unidades de processamento.

Nas unidades de processamento de Gás Natural, conhecidas como UPGNs, os componentes do gás natural são separados em produtos especificados e prontos para utilização. Nesta etapa, o gás é desidratado (é retirado o vapor d'água) e fracionado. Nesse fracionamento são obtidos: metano e etano; propano e butano; pentano, hexano, heptano e hidrocarbonetos superiores. Os produtos obtidos nesse processo são:

- Gás processado ou residual, formados pelo metano e etano; 
- GLP (gás liquefeito do petróleo, o "gás de cozinha"), formado pelo propano e butano;

- Gasolina natural, formada pelo pentano, hexano e heptano.

O gás natural seco, resultado do processamento de gás natural úmido é transportado (nos estados gasoso, líquido ou comprimido) e distribuído (distribuição de gás) para consumo como energia final (gás) para uso térmico na indústria, para uso térmico no setor comercial e serviços, como combustível para automóveis. É também utilizado em plantas de GTL (GTL Gas to Liquids) para produção de não energéticos de petróleo e como insumo na petroquímica. Por fim, pode ser utilizado na geração de energia elétrica no SIN e Sistemas isolados através das tecnologias de geração termelétrica a ciclo aberto e a ciclo combinado.

O gás natural compete potencialmente com alguns energéticos derivados de petróleo, principalmente, quanto ao uso para geração de energia elétrica, com:

- Óleo pesado (basicamente óleo combustível)

- Óleo diesel

\subsubsection{Gás Natural no Mundo}

Segundo a BP Statistical Review of World Energy June 2008, na seção gás natural, no mundo as maiores reservas provadas de Gás Natural encontram-se no Oriente Médio e na Europa/Eurásia com respectivamente 73,21 e 59,41 trilhões de metros cúbicos. Em seguida, com valores muito inferiores, vem África e Ásia/Pacífico com quase 14,50 trilhões de metros cúbicos cada uma. Só depois aparecem as Américas do Norte e Central junto com a do Sul com respectivamente 7,98 e 7,73 trilhões de metros cúbicos. Já a produção vem aumentando consideravelmente na Ásia/Pacífico e no resto do mundo, embora os maiores produtores sejam a Europa e Eurásia e a América do Norte. A mesma análise anterior serve para o consumo mundial.

A dinâmica futura do comércio global de gás natural está condicionada a aspectos econômicos, geopolíticos e tecnológicos. A emergência de um mercado globalizado de gás natural, não apenas regionalizado, depende de investimentos na infra-estrutura de gás natural liquefeito e em novos gasodutos, que por sua vez se relacionam à atratividade de diferentes mercados / países.

No caso do Brasil, além destes condicionantes o aspecto regulatório merece destaque. Na América do Sul, a convergência de marcos regulatório entre países, a consolidação de um 
arranjo comercial e institucional, a dinamização da estrutura da indústria são desafios que precisam ser transpostos com sucesso.

O Brasil atualmente não se situa dentre os países com alto volume de importação, entretanto, no que se refere ao patamar de preço do gás natural importado no país, este está relacionado aos demais preços nos mercados globais a serem atendidos.

Na América do Sul, a Venezuela é o país com maior reserva provada e o maior potencial exportador de gás natural no continente. Atualmente não exporta gás natural.

Para completar o abastecimento do mercado consumidor, o Brasil importa gás natural da Bolívia. O aumento de importação da Bolívia, ou nova importação da Venezuela (ou Peru, ou Trinidad \& Tobago) e da Argélia, na forma liquefeita, são possibilidades para os próximos anos.

De janeiro de 2006 a junho de 2008, segundo dados da ANP/SCM - Superintendância de Comercialização e Movimentação de Petróleo, seus Derivados e Gás Natural-, o volume médio diário foi de $28.435 \mathrm{mil} \mathrm{m}^{3}$ por dia de um total de $853.037 \mathrm{mil} \mathrm{m}^{3}$. A Petrobrás é a maior importadora representando nesse período $94 \%$ do total importado.

Segundo dados da Secretaria de Comércio Exterior - SECEX foram comercializados em 2007 US\$ F.O.B. 1.255.453.559 de produtos importados da Bolívia; 90,9\% disso (US\$ F.O.B. 1.141.158.349) se referem à importação de Gás Natural no Estado Gasoso.

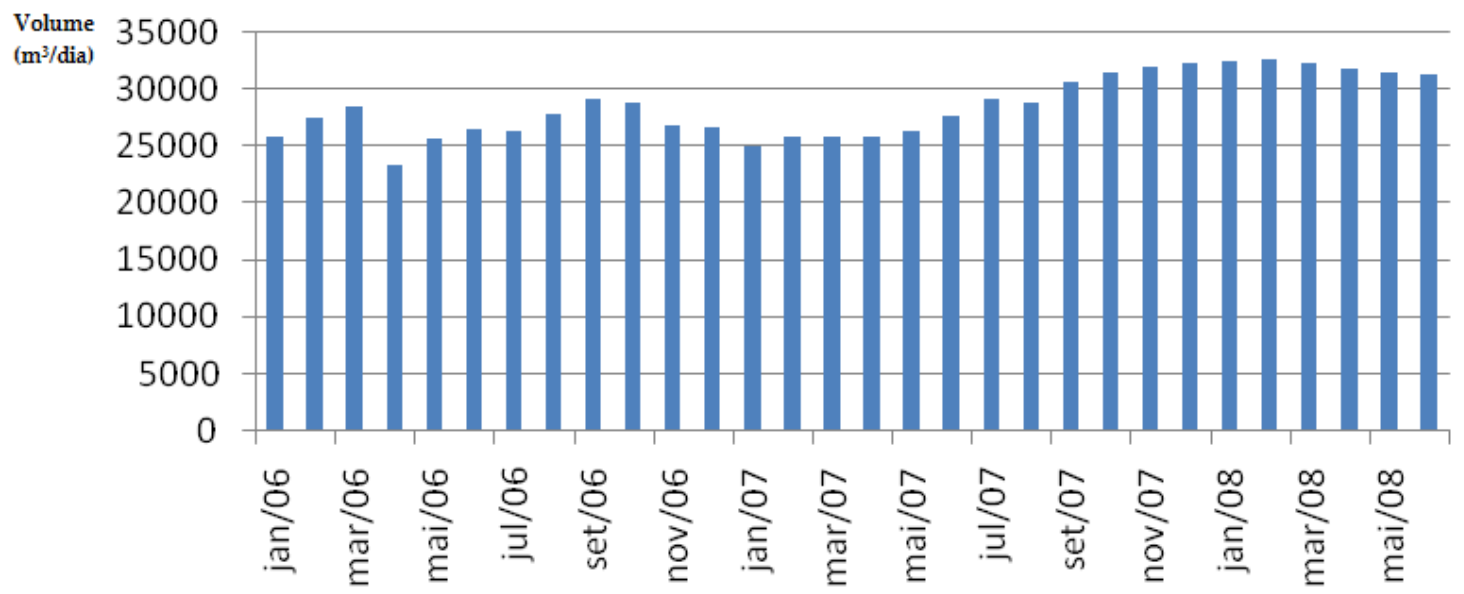

Fig. 3.2 - Volume total importado de gás natural (mil m³ por dia) 


\subsubsection{Gás Natural no Brasil}

Segundo o boletim de junho de 2008 da ANP, analisando o período compreendido entre os anos de 1964 e 2007, as reservas provadas de gás natural cresceram a uma taxa média de $7,7 \%$ a.a. Este crescimento está relacionado principalmente às descobertas decorrentes do esforço contínuo do país para diminuir o grau de dependência do petróleo. As principais descobertas ocorreram na Bacia de Campos (bacia sedimentar onde se encontra a maior concentração de campos gigantes do país, tais como Albacora, Marlim e Roncador), bem como na Bacia do Solimões (bacia sedimentar onde se encontram o Pólo de Urucu - local onde boa parte do gás é reinjetado, e a jazida de Juruá, ainda sem aplicação comercial).

A evolução das reservas de gás natural no país apresenta um comportamento muito próximo ao das reservas de petróleo, devido principalmente à ocorrência de gás natural sob a forma associada. Há, no entanto, a expectativa de que novas reservas de gás natural sejam descobertas, eminentemente sob a forma não-associada, tal como é sinalizado pelas descobertas recentes na Bacia de Santos. As reservas possuem um grau de incerteza quanto à recuperação do gás e por isso são classificadas em: Provadas, Prováveis e Possíveis. Sendo que esta última possui maior incerteza dentre todas. A reserva total é composta pela soma de todas.

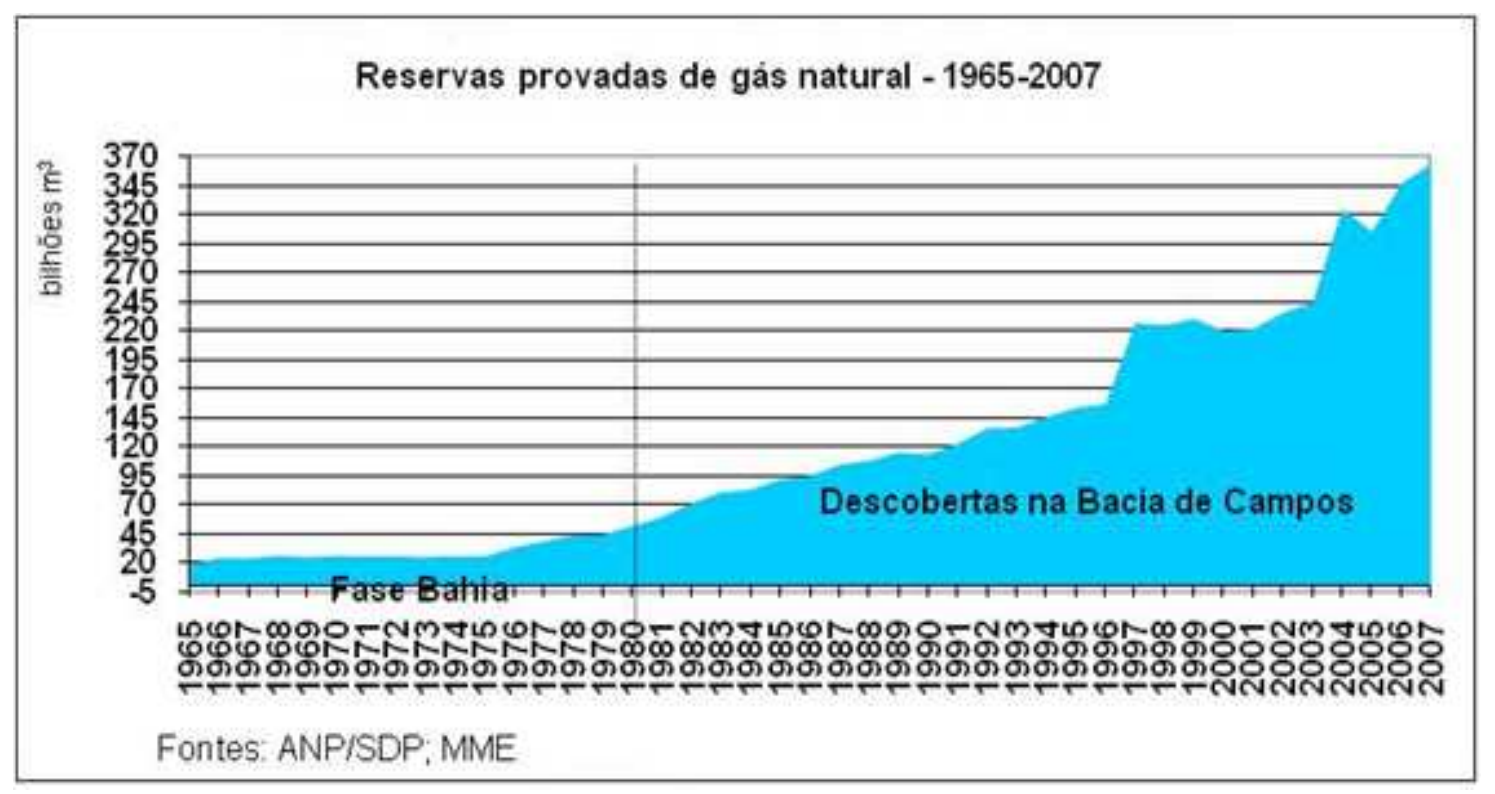

Fig. 3.3 - Reservas provadas de gás natural no Brasil

A maioria das reservas de gás está na forma associada sendo que cerca de $20 \%$ delas estão em terra, enquanto que aproximadamente $80 \%$ estão no mar. 
Tabela 3.2 - Reservas de Gás Natural no Brasil

\begin{tabular}{|c|c|c|c|c|c|c|c|}
\hline \multirow[b]{2}{*}{ Local } & \multirow[b]{2}{*}{ Estado } & \multicolumn{3}{|c|}{ Reservas Provadas } & \multicolumn{3}{|c|}{ Reservas Totais } \\
\hline & & Petróleo (milhöes m?) & Petróleo (milhöes barris) & Gás (milhöes m?) & Petróleo (milhöes m?') & Petróleo (milhöes barris) & Gás (milhöes m?) \\
\hline \multirow{14}{*}{ Terra } & Alagoas & 1,37 & 8,65 & $3.008,80$ & 3,13 & 19,66 & $4.739,01$ \\
\hline & Amazonas & 16,04 & 100,88 & $51.132,16$ & 22,71 & 142,86 & $59.005,13$ \\
\hline & Bacia do Amazonas & 0,00 & 0,00 & 0,00 & 0,00 & 0,00 & 0,00 \\
\hline & Bacia do Solimoes & 16,04 & 100,88 & $51.132,16$ & 22,71 & 142,86 & $59.005,13$ \\
\hline & Bahia & 34,36 & 216,14 & $8.341,90$ & 75,21 & 473,08 & $16.109,28$ \\
\hline & Bacia de Camamu-Almada & 0,00 & 0,00 & 0,00 & 0,00 & 0,00 & 0,00 \\
\hline & Bacia do Recóncavo & 34,34 & 216,00 & $8.018,86$ & 75,19 & 472,94 & $15.786,25$ \\
\hline & Bacia do Tucano Sul & 0,02 & 0,14 & 323,03 & 0,02 & 0,14 & 323,03 \\
\hline & Cearáa & 1,34 & 8,40 & 0,00 & 4,36 & 27,45 & 0,00 \\
\hline & Espinito Santo & 8,59 & 54,01 & $1.106,42$ & 13,51 & 85,00 & $1.392,15$ \\
\hline & Paraná & 0,00 & 0,00 & 1,12 & 0,00 & 0,01 & 760,70 \\
\hline & Rio Grande do Norte & 42,07 & 264,60 & $1.936,01$ & 56,82 & 357,40 & $2,433,17$ \\
\hline & Sergipe & 36,85 & 231,82 & 761,29 & 53,88 & 338,87 & 922,76 \\
\hline & SUB-TOTAL & 140,62 & 884,49 & $66.287,69$ & 229,62 & $1.444,33$ & $85.362,19$ \\
\hline \multirow{16}{*}{ Mar } & Alagoas & 0,12 & 0,73 & 850,04 & 0,14 & 0,91 & $1.060,57$ \\
\hline & Bahia & 3,31 & 20,82 & $26.423,02$ & 13,50 & 84,91 & $29.143,26$ \\
\hline & Bada de Camamu-Almada & 3,17 & 19,96 & $26.423,02$ & 9,14 & 57,48 & $29.143,26$ \\
\hline & Bacia do Recóncavo & 0,14 & 0,86 & 0,00 & 4,36 & 27,43 & 0,00 \\
\hline & Ceará & 9,15 & 57,54 & 824,58 & 11,83 & 74,41 & $1.097,02$ \\
\hline & Espinito Santo & 119,80 & 753,57 & $31.054,90$ & 200,43 & $1.260,72$ & $41.134,54$ \\
\hline & Bacia de Campos & 96,68 & 608,15 & $8.232,40$ & 172,68 & $1.086,13$ & $13.461,71$ \\
\hline & Badia do Espirito Santo & 23,12 & 145,43 & $22.822,50$ & 27,76 & 174,59 & $27.672,83$ \\
\hline & Paraná2 ${ }^{2}$ & 2,38 & 14,99 & 559,13 & 6,74 & 42,39 & $1.598,23$ \\
\hline & Rio de Janeiro ' & $1.517,90$ & $9.547,62$ & $135.206,58$ & $2.174,33$ & $13.676,54$ & $191.134,78$ \\
\hline & Bacia de Campos & $1.517,90$ & $9.547,62$ & $135.206,58$ & $2.122,63$ & $13.351,34$ & $188.634,78$ \\
\hline & Bacia de Santos & 0,00 & 0,00 & 0,00 & 51,70 & 325,19 & $2.500,00$ \\
\hline & Rio Grande do Norte & 15,14 & 95,24 & $10.303,64$ & 26,29 & 165,38 & $11.667,08$ \\
\hline & Sâo Paulo & 0,21 & 1,31 & $1.186,40$ & 0,78 & 4,88 & $2.966,66$ \\
\hline & Sergipe & 5,51 & 34,64 & $2.841,88$ & 21,20 & 133,36 & $4.794,36$ \\
\hline & SUB-TOTAL & $1.673,52$ & $10.526,46$ & $209.250,16$ & 2455,24 & $15.443,49$ & $284.596,49$ \\
\hline \multicolumn{2}{|l|}{ TOTAL } & & $11.410,95$ & $275.537,86$ & $2.684,87$ & $16.887,81$ & $369.958,68$ \\
\hline
\end{tabular}

Fonte: ANP

Segundo previsões da Petrobrás, as descobertas na Bacia de Santos nos campos BS- 400 (Mexilhão) e BS-500, estima-se em 419 bilhões de $\mathrm{m}^{3}$ as reservas de gás natural, confirmando como a principal aposta para a produção de gás natural no Brasil. Existem projetos em andamento na Bacia de Campos para aumentar a produção de gás natural, em especial nos Campos Barracuda, Caratinga, Albacora Leste e Marlim Leste, além de novos módulos nos Campos Roncador e Marlim Sul. No Espírito Santo, a operação do projeto offshore PeroáCangoá, do campo de Golfinho, para 2007 elevam em cerca de 10 milhões de m³/dia a produção da Bacia.

Devido à grande capacidade de produção deve haver também uma grande capacidade de processamento. O processamento de gás natural, realizado nas Unidades de Processamento de Gás Natural (UPGNs), tem como principal objetivo garantir a especificação do gás para os consumidores finais do produto, o qual passa a denominar-se gás seco, gás processado ou gás residual - essencialmente formado por metano e etano - e uma corrente de Líquido de Gás Natural (LNG) - formada por frações mais pesadas que o propano - que dá origem ao Gás Liquefeito de Petróleo (GLP) e Gasolina Natural. A capacidade nominal de processamento atualmente totaliza 52,7 milhões $\mathrm{m}^{3} / \mathrm{dia}$.

Na Região Nordeste a capacidade instalada de processamento totaliza 17,2 milhões $\mathrm{m}^{3} /$ dia, o que representa $32,6 \%$ da capacidade brasileira. Já na região Sudeste, que possui uma 
capacidade de processamento de 23,7 milhões $\mathrm{m}^{3} / \mathrm{dia}$, ocupando o primeiro lugar no ranking nacional e representando 45,0\% da capacidade nacional, o gás natural é processado nos Estados do Espírito Santo, São Paulo e, predominantemente, no Rio de Janeiro. Na região Norte encontram-se as UPGNs de Urucu (AM), cuja produção destina-se, até o momento, à recuperação do LGN do gás produzido, sendo o gás seco reinjetado no reservatório, em decorrência da falta de infra-estrutura para o escoamento da produção até áreas de possível mercado. Esta região tem a capacidade de processar 9,6 milhões $\mathrm{m}^{3} / \mathrm{dia}$ de gás natural, representando $18,2 \%$ da atual infra-estrutura de processamento de todo o Brasil.

Em decorrência da expectativa de aumento da produção no país, novos investimentos estão previstos para o setor de processamento de gás natural. No momento, os planos contemplam a implantação de três novas unidades, as quais permitirão uma expansão de cerca de 13,1 milhões de $\mathrm{m}^{3} / \mathrm{dia}$ na capacidade de processamento de gás natural. Estes projetos incluem a Estação de Tratamento de São Francisco no Estado da Bahia, a UPGN Cacimbas e a DPP Cacimbas ambas no Estado do Espírito Santo.

As reservas de gás estão distribuídas nos estados brasileiros segundo o seguinte gráfico:

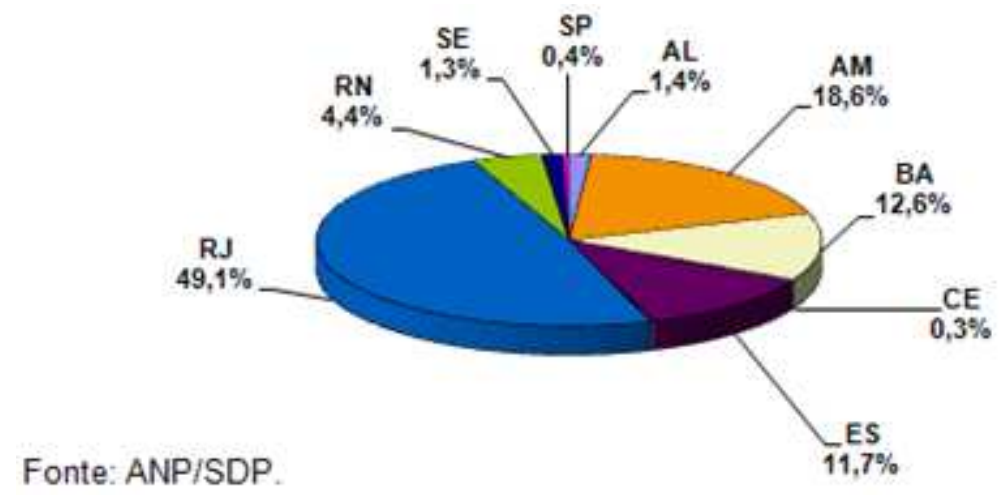

Fig. 3.4 - Distribuição percentual das reservas provadas de gás natural, por Unidades da Federação

A produção de gás natural no Brasil aumentou perceptivelmente desde dezembro de 2007 até junho de 2008, aumentando nesse intervalo de tempo em $5 \mathrm{mil} \mathrm{m}^{3}$ por dia. No geral, vê-se que o consumo de gás natural está aumentando, de modo que a importação e a produção nacional também estão numa escala ascendente conforme as figuras 3.5 e 3.6. 

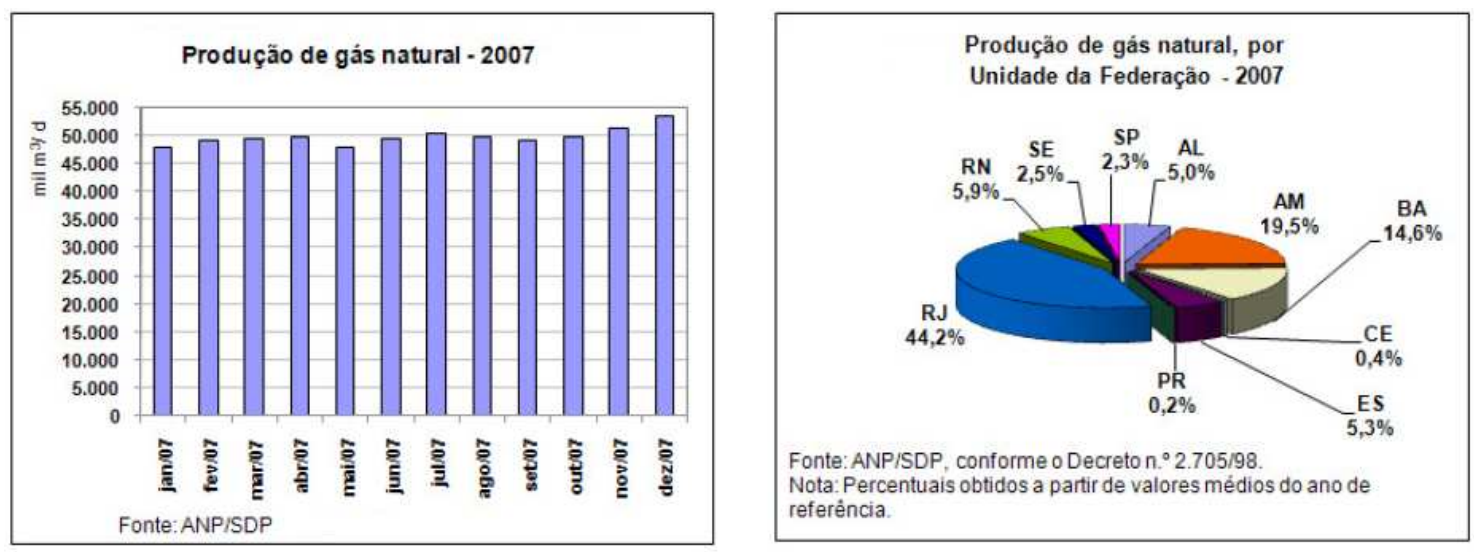

Fig. 3.5 - Produção de Gás Natural em 2007 e participação por estado

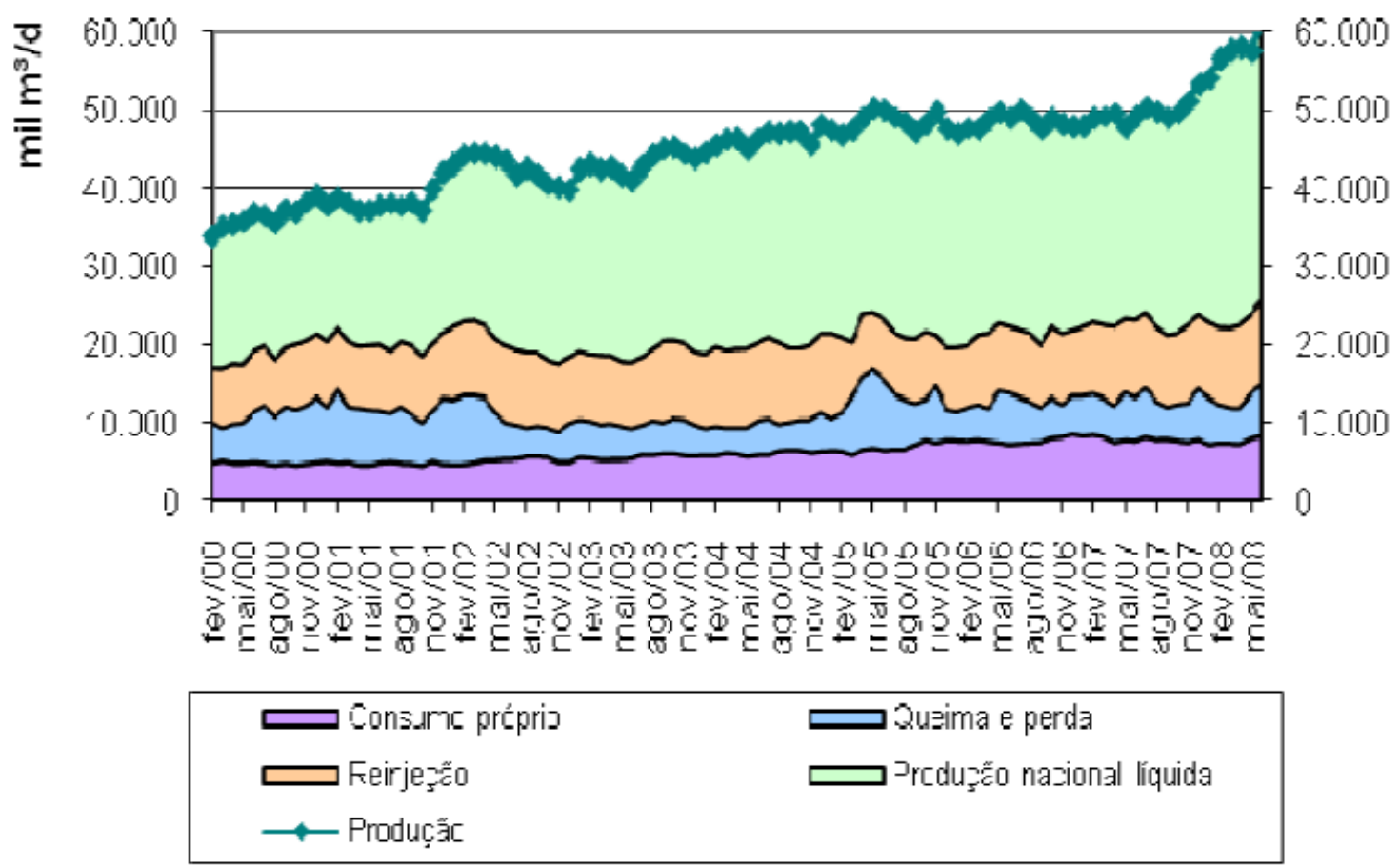

Fig. 3.6 - Produção nacional de gás natural

Fonte: ANP/SCM; ANP/SDP

Do volume total extraído parte é perdida e queimada, parte é consumida, parte é reinjetada, parte vira GNL (hidrocarbonetos mais pesados). 


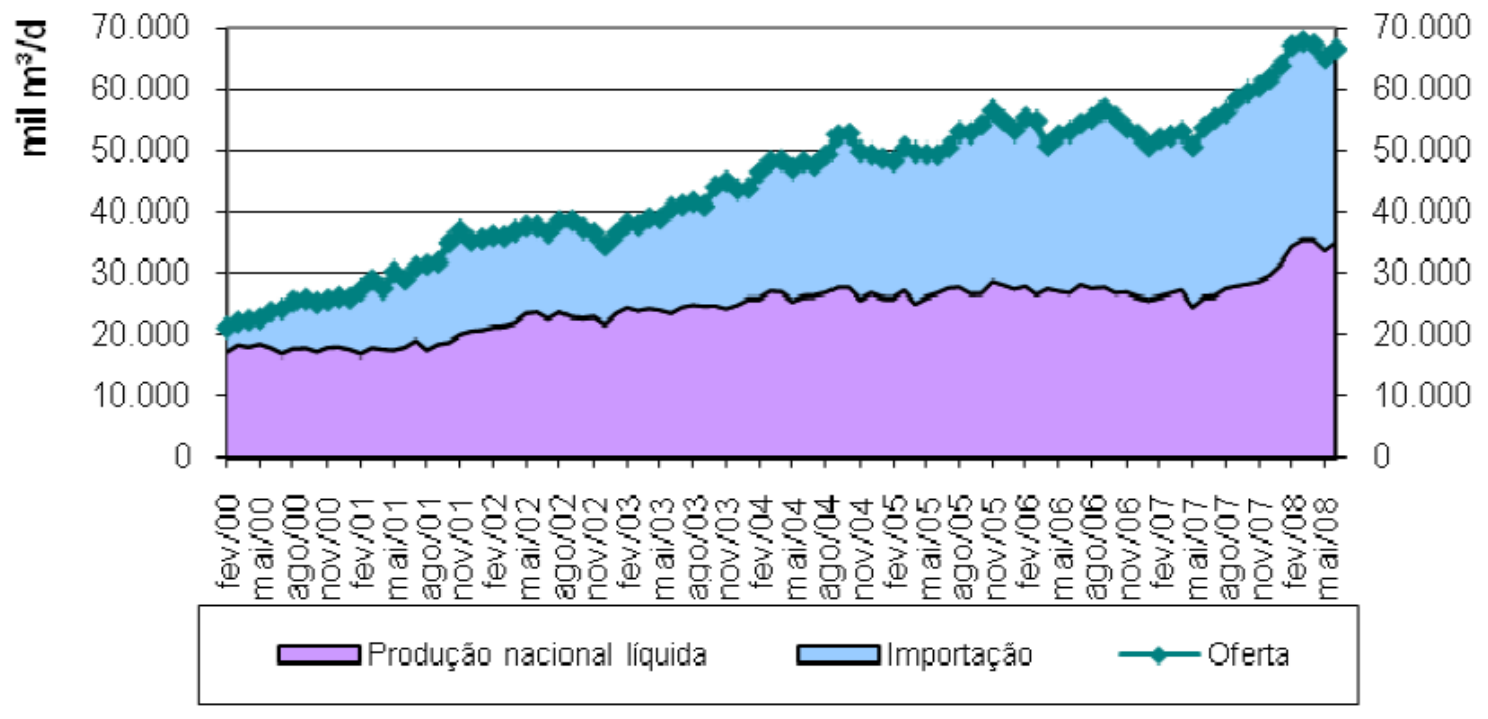

Fontes: ANP/SCM; ANP/SDP

(1) Equivale ao mercado aparente e inclui LGN, ajustes de balanço, outros consumos internos nas operaçöes com gás natural e consumo em refinarias.

Fig. 3.7 - Composição da oferta de gás natural

\subsection{Leis Pertinentes}

'LEI DO PETRÓLEO: LEI N 9.478, DE 6.8.1997 - Dispõe sobre a política energética nacional, as atividades relativas ao monopólio do petróleo, institui o Conselho Nacional de Política Energética e a Agência Nacional do Petróleo e dá outras providências.

"As políticas nacionais para o aproveitamento racional das fontes de energia visarão aos seguintes objetivos:

II - promover o desenvolvimento, ampliar o mercado de trabalho e valorizar os recursos energéticos;

III - proteger os interesses do consumidor quanto a preço, qualidade e oferta dos produtos;

IV - proteger o meio ambiente e promover a conservação de energia;

VI - incrementar, em bases econômicas, a utilização do gás natural;

VII - identificar as soluções mais adequadas para o suprimento de energia elétrica nas diversas regiões do País;

VIII - utilizar fontes alternativas de energia, mediante o aproveitamento econômico dos insumos disponíveis e das tecnologias aplicáveis;

IX - promover a livre concorrência;

$X$ - atrair investimentos na produção de energia;

XI - ampliar a competitividade do País no mercado internacional.

XII - incrementar, em bases econômicas, sociais e ambientais, a participação dos biocombustíveis na matriz energética nacional.” 
"Pertencem à União os depósitos de petróleo, gás natural e outros hidrocarbonetos fluidos existentes no território nacional, nele compreendidos a parte terrestre, o mar territorial, a plataforma continental e a zona econômica exclusiva.

Constituem monopólio da União, nos termos do art. 177 da Constituição Federal, as seguintes atividades:

I - a pesquisa e lavra das jazidas de petróleo e gás natural e outros hidrocarbonetos fluidos;

III - a importação e exportação dos produtos e derivados básicos resultantes das atividades previstas nos incisos anteriores;

IV - o transporte marítimo do petróleo bruto de origem nacional ou de derivados básicos de petróleo produzidos no País, bem como o transporte, por meio de conduto, de petróleo bruto, seus derivados e de gás natural."

(com alterações Arts. $3^{\circ}$ e $4^{\circ}$ )

PORTARIA ANP $\mathrm{N}^{\circ}$ 43, DE 15.4.1998 - Estabelece a regulamentação para a importação de gás natural.

PORTARIA ANP $\mathrm{N}^{\circ}$ 170, DE 26.11.1998 - Estabelece a regulamentação para a construção, a ampliação e a operação de instalações de transporte ou de transferência de petróleo, seus derivados, gás natural, inclusive liquefeito, biodiesel e misturas óleo diesel/biodiesel.

É importante destacar que a importação, a construção, ampliação e operação relacionadas ao gás natural dependem de expressa autorização da ANP.

\subsection{Cadeia de Valor do Gás Natural}

A estrutura da indústria de gás natural desde a sua extração até chegar ao consumo final, pode ser dividida em: exploração e produção, processamento, transporte, armazenamento, distribuição, comercialização e consumo. Essas atividades são interdependentes. Apesar de possuírem características técnicas e econômicas distintas, é o seu conjunto que compõe a cadeia de valor do gás natural.

Considerando o GNL, como a principal forma de interesse na atualidade do gás natural, a sua cadeia é um dos ramos tecnológicos possíveis de desenvolvimento da indústria do gás natural, permitindo conduzir o gás de campos de produção muitas vezes remotos até os consumidores, adicionando valor a um gás natural que, em outras condições, provavelmente não 
encontraria comprador disposto a pagar o preço requerido pelo produtor. Por isso será dada uma ligeira ênfase nessa forma de gás natural.

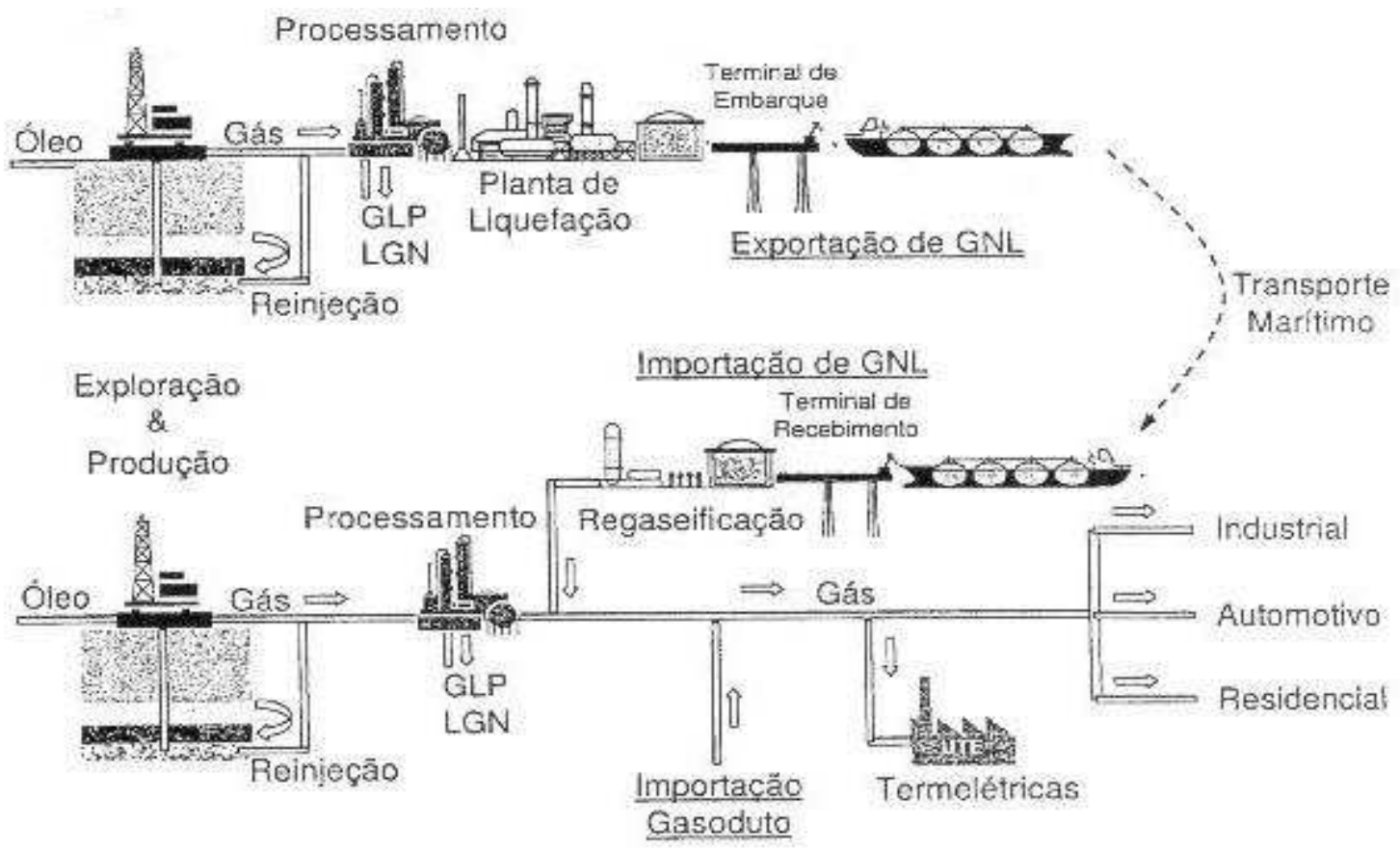

Fig. 3.8 - Cadeia de valor do Gás Natural e do GNL

Fonte: GNL como mecanismo de flexibilização do suprimento de gás natural para geração termelétrica no Brasil, 2008.

\section{Exploração e produção}

Também conhecidas como upstream, as atividades de exploração e produção de petróleo e gás natural são compostas pelas etapas de pesquisa ou prospecção, avaliação, desenvolvimento e produção. São atividades que requerem altos níveis de investimento e envolvem elevados riscos econômicos, mas representam o maior negócio da cadeia de valor, cuja viabilidade econômica está diretamente relacionada à quantidade das reservas recuperáveis (volumes comercializáveis) e o acesso a mercados nos quais os produtos possam ser adequadamente recuperados.

\section{Processamento}

O processamento do gás natural é o conjunto de operações destinadas a permitir o seu transporte, distribuição e consumo, adequando a composição do gás natural às especificações estabelecidas para o respectivo mercado. Essas operações são realizadas nas UPGNs, que são instalações industriais que podem possuir complexidade tecnológica e escalas variadas. 
No caso do gás no estado líquido, as plantas de liquefação são unidades específicas de processamento, destinadas à conversão do gás natural do estado gasoso para o líquido, originando o GNL. Os terminais de regaseificação fazem o oposto.

\section{$\underline{\text { Transporte }}$}

No Brasil a Lei 9.478, de 6 de agosto de 1997, define o transporte como a movimentação de gás natural em meio ou percurso considerado de interesse geral e chama de transferência a movimentação de gás natural em meio ou percurso considerado de interesse específico e exclusivo do proprietário ou explorador das facilidades.

Entende-se por infra-estrutura de transporte de gás natural a rede de gasodutos que transporta o gás natural seco até os pontos de entrega às distribuidoras estaduais. Totalizando $5.433,2 \mathrm{~km}$ de rede e capacidade de transporte de 71,5 milhões de $\mathrm{m}^{3} / \mathrm{dia}$, dos quais 45,9\% são operados pela Petrobras/Transpetro, esta infra-estrutura é composta por uma malha que escoa gás natural de origem nacional e outra que escoa produto importado,

Os gasodutos que transportam gás de origem nacional são ativos da Petrobras, da Transpetro, da Nova Transportadora do Nordeste - NTN e Transportadora Nordeste Sudeste TNS e somam 2.533,2 km de extensão. A malha de gasodutos que escoa produto importado é formada pelo gasoduto Bolívia-Brasil (operado pela TBG), pelo Gasoduto Uruguaiana-Porto Alegre (trechos 1 e 3 - operado pela TSB) e pelo Gasoduto Lateral Cuiabá (operado pela Gasocidente), perfazendo um total de 2.900,0 km, com capacidade de escoamento de 35,3 milhões de $\mathrm{m}^{3} / \mathrm{dia}$.

Vale destacar que pela expectativa de incremento do mercado de gás natural, diversos projetos estão sendo desenvolvidos para expansão da infra-estrutura de transporte do energético no país e que deverão entrar em operação até 2010. Desses projetos destacam-se os empreendimentos integrantes do Projeto Malhas e a expansão de capacidade do Gasoduto Bolívia - Brasil, como se evidencia nas figuras 3.9, 3.10 e 3.11. 


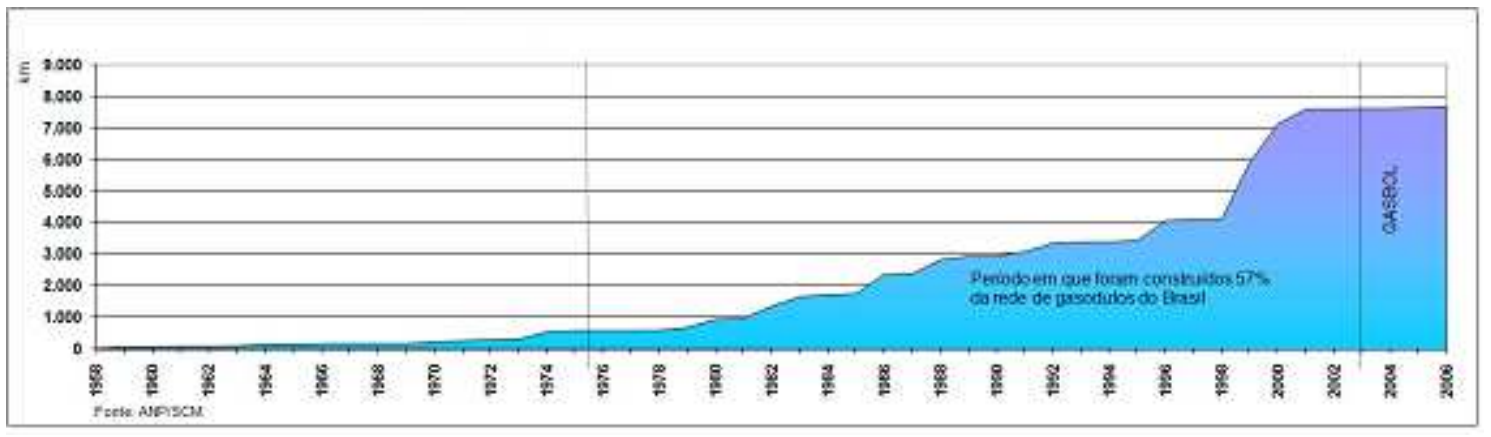

Fig 3.9 - Evolução da malha de gasodutos

Fonte: ANP

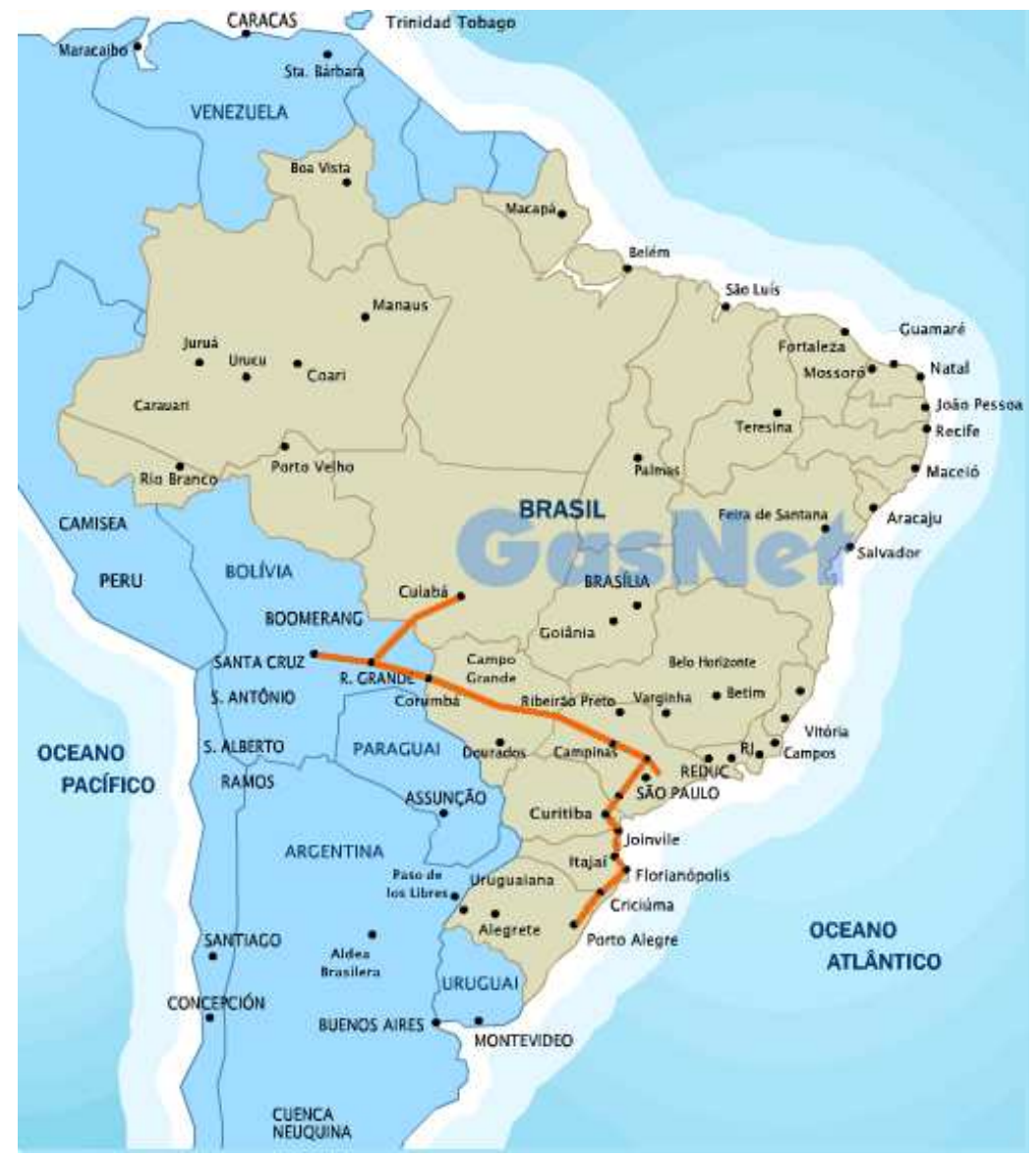

Fig. 3.10 - GASBOL - Gasoduto Brasil-Bolívia

Fonte: Gasnet 


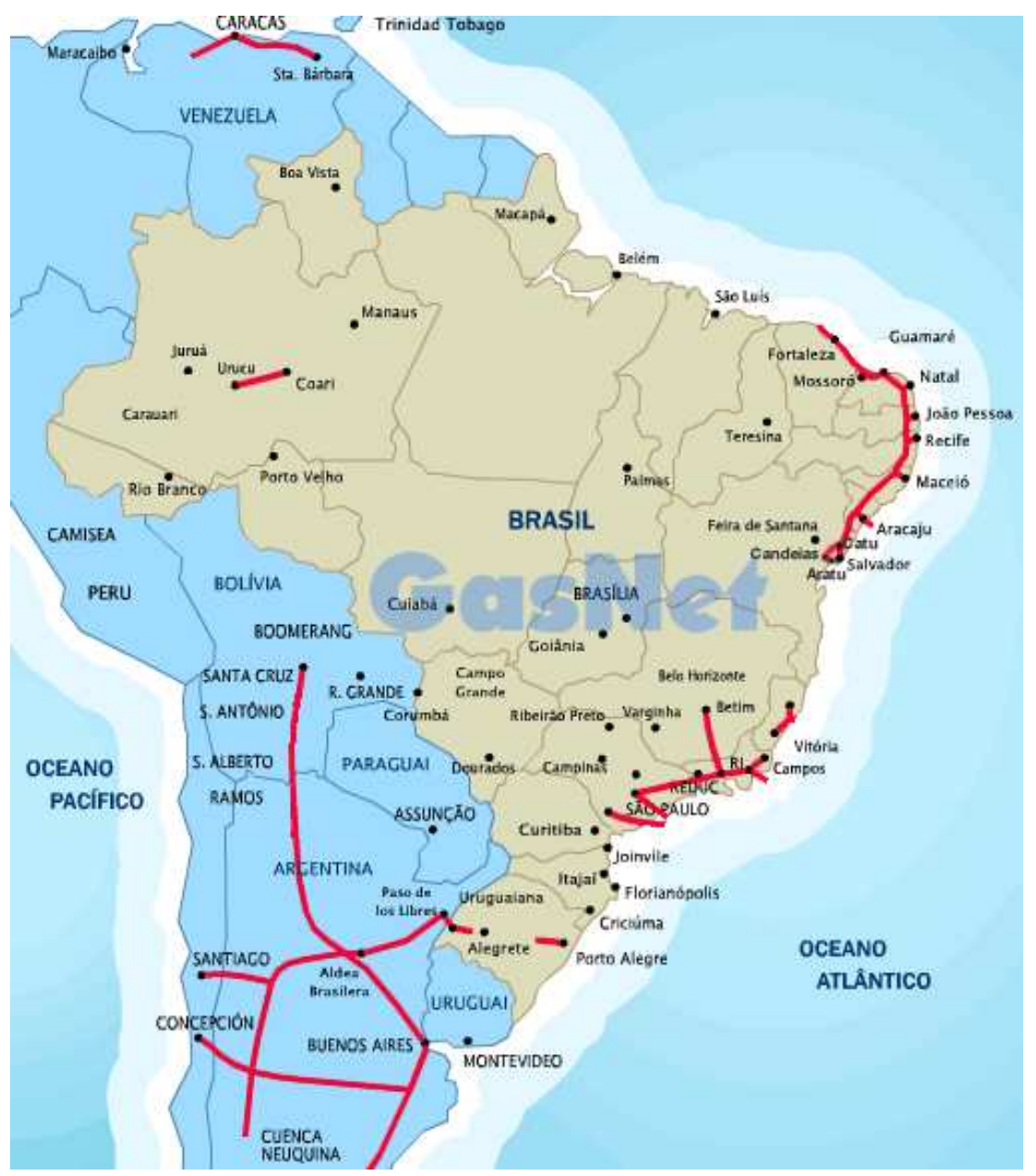

Fig. 3.11 - Gasodutos em Operação

Fonte: Gasnet

Um dos principais projetos de incremento da malha de transporte é o Gasoduto Sudeste Nordeste (Gasene), obra integrante do Programa de Aceleração do Crescimento (PAC), com $1.387 \mathrm{~km}$ de extensão. O Gasene é a maior obra de engenharia de construção e montagem de dutos no país, desde a conclusão do Gasoduto Bolívia-Brasil. O empreendimento é um marco na infra-estrutura de gasodutos no Brasil. Permitirá interligar as malhas de transporte das regiões Sudeste e Nordeste e terá capacidade para transportar 20 milhões de metros cúbicos/dia.

Segundo BP Statistical Review of World Energy June 2008, a maioria do transporte do gás natural ocorre por gasodutos, $70,8 \%$ do volume comercializado internacionalmente.

Por ser um produto no estado gasoso nas condições ambiente e, crescentemente, suas áreas de produção se encontrarem distantes dos mercados consumidores - como é o caso do Brasil por ter a maioria de suas reservas de gás no mar-, o transporte de gás natural pode ocorrer por gasodutos (forma gasosa); trens, navios e caminhões criogênicos (forma líquida) ou em cilindros de alta pressão. O Gás natural comprimido (GNC) em navios permite uma compressão de volume da ordem de 200 vezes menor, já os gasodutos estão na ordem de 90 vezes enquanto 
que o GNL está em torno de 600 vezes menor. O transporte de GNL é efetuado em navios de casco duplo projetados especialmente para lidar com a baixa temperatura do produto, reduzindo sua evaporação.

Quanto às formas de gás natural temos o gás natural comprimido (GNC) que é o gás comprimido a cerca de $200 \mathrm{kgf} / \mathrm{cm}^{2}$ à temperatura atmosférica; para transportes em cilindros especiais temos o GNL (gás natural liquefeito) que é o gás natural que se torna líquido quando resfriado a $161^{\circ} \mathrm{C}$ negativos e à pressão ambiente. O Gás Natural (GN) sem especificação é entendido como aquele normalmente transportado através de gasodutos de alta pressão ( $80 \mathrm{a}$ $\left.100 \mathrm{kgf} / \mathrm{cm}^{2}\right)$.

\section{$\underline{\text { Armazenamento }}$}

As instalações de armazenamento de gás natural ficam interligadas aos sistemas de distribuição ou transporte, com o objetivo de regularizar o fluxo de entrega final do gás natural, reduzindo flutuações na entrega.

A estocagem do gás natural pode ser efetuada com o gás sob pressão em formações geológicas porosas e permeáveis, bem como na forma líquida GNL em tanques criogênicos. Esses tanques são termicamente isolados e construídos especificamente para minimizar a evaporação do GNL e garantir sua auto-refrigeração.

\section{Distribuição}

Comparativamente ao transporte que pode ser interpretado como a movimentação de grandes volumes entre as regiões de produção e de consumo, por meio de uma malha. A distribuição pode ser definida como a movimentação de pequenos volumes de pontos da malha de transporte até cada consumidor final. Essa interface é feita por pontos de entrega e recebimento, os chamados city gates, que são estações de medição e regulagem de pressão, em que se efetuam o controle da vazão de entrega para a região de consumo, quando a rede de distribuição acessa as áreas urbanas.

É possível ter o GNC e o GNL distribuídos através de caminhões, trens, barcaças ou navios de cabotagem. Para esses sistemas se popularizou o conceito de gasoduto virtual. $\mathrm{O}$ gasoduto virtual é a saída para regiões onde a demanda não compensa um investimento em gasodutos. Por outro lado, o gás distribuído através de redes de baixa e média pressão é denominado de gás encanado ou de rua. 
A tecnologia do "Gasoduto virtual" engloba um sistema de distribuição de gás natural em três etapas: a primeira constitui-se da compressão do gás natural (gás natural comprimido ou GNC) em uma Estação de Compressão. A segunda, do transporte do energético por carreta. Já, a terceira prevê a descompressão do GNC transportado via carreta em uma Estação de Descompressão localizada no município de entrega e sua distribuição, por meio de uma rede secundária, até os clientes finais.

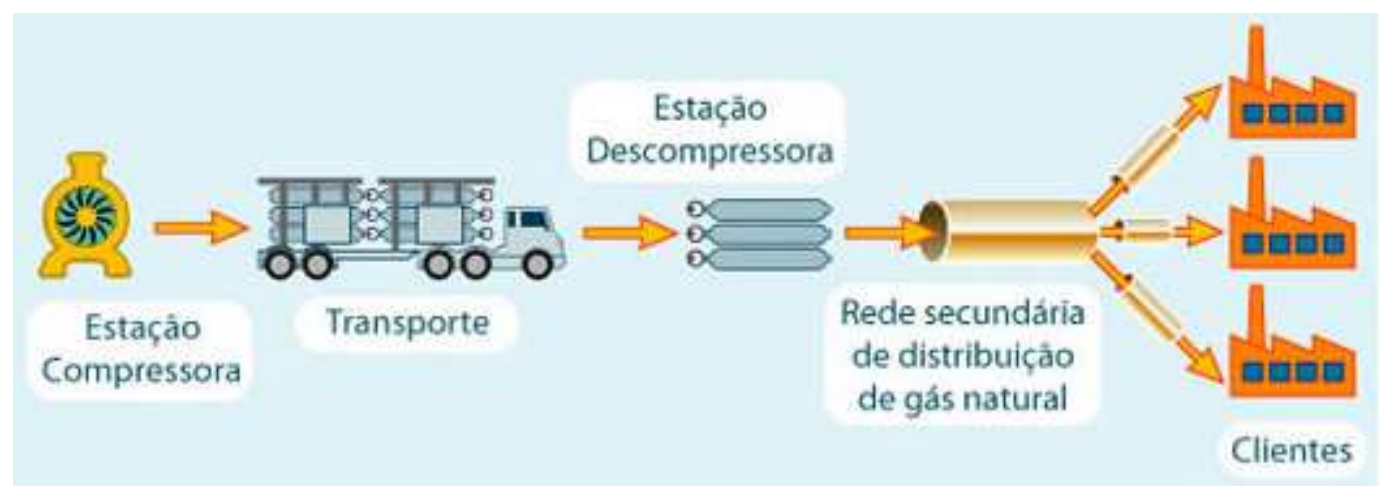

Fig. 3.12 - 'Gasoduto Virtual'

Fonte: Gás Natural São Paulo Sul

\section{Consumo final}

Os usos tradicionais do gás natural podem ser divididos em: energéticos, que são aquecimento e condicionamento ambiental, cocção, geração de eletricidade, além de combustível para veículos (GNV) e não-energéticos, principalmente como matéria-prima (petroquímica, fertilizante, metanol, redutor, siderúrgico, hidrogênio etc.).

Os seguimentos do mercado consumidor de gás natural são: residencial, comercial e serviços, industrial, automotivo, co-geração e geração de eletricidade.

\subsection{Fundamentos Econômicos do Gás Natural}

As transações comerciais, visando o fornecimento de gás natural normalmente implicam em um complexo conjunto de relações entre as várias partes envolvidas ao longo da cadeia de valor. A indústria do Gás Natural possui característica tanto de indústria extrativista, nas atividades de upstream, quanto de rede, quando se utiliza o modal dutoviário. É uma indústria que tenta se aproximar da indústria petroleira quando o gás assume a forma de GNL.

O desenvolvimento da indústria gasífera está condicionado à construção de transporte e distribuição que preserve a competitividade do energético, pois os custos dessas duas etapas da 
cadeia de valor são determinantes para o preço final do combustível. Assim, os riscos associados ao desenvolvimento da cadeia são muitos, e ultrapassam aqueles encontrados na indústria do petróleo. Os segmentos da cadeia possuem forte interdependência, visto que cada um deles é essencial para que seja possível a valorização dos recursos naturais descobertos no subsolo. Todos os investimentos precisam ter um retorno adequado para a partilha da renda total gerada no negócio. Logo, é necessária a garantia de consumo final e remuneração adequada. Todavia deve-se lembrar que em qualquer investimento há riscos associados.

Trata-se de investimentos específicos, visto que os ativos construídos não podem ser reaproveitados em outros ramos sem a perda de seu valor original. Existem diversos agentes atuando ao longo da cadeia de valor, cada um com seus interesses e obrigações de investimento, sendo que um agente pode se tornar mais vulnerável ao maior poder de flutuação do mercado.

Nenhuma das partes em uma transação comercial desejará antecipar investimentos, cuja renda poderá ser apropriada por outro agente. Cabe então à regulação aperfeiçoar as relações ao longo da cadeia. Deve haver a restrição de comportamentos oportunistas.

Em um ambiente de convergência entre gás e eletricidade, a cadeia vertical do gás pode integrar-se até o uso final, ou seja, a usina termelétrica transformará em eletricidade a energia química que será o único produto a chegar ao consumidor final. Este realizará todos os investimentos ao longo da cadeia, assumindo todos os riscos do negócio.

Desta forma, baseando-se no ambiente regulatório, além de desenvolvimento de mercado e infra-estrutura, os agentes definirão as condições de atratividade econômica de cada transação comercial.

Do ponto de vista contratual, predomina os contratos de longo prazo com cláusulas que buscam garantir o repasse de compromissos específicos de um elo da cadeia para outro. As principais cláusulas contratuais são:

a) Cláusula de Take or Pay (ToP)- Representa o compromisso do consumidor de garantia de uma receita mínima para o produtor, necessária, em última instância, à remuneração dos investimentos em exploração e produção;

b) Cláusula de Ship or Pay (SoP)- Representa o compromisso do carregador (agente que contrata o serviço da infra-estrutura de transporte de gás natural) de garantia de uma receita mínima para essa etapa, necessária à remuneração dos investimentos em transporte; 
c) Cláusula Deliver or Pay (DoP)- Representa o compromisso do produtor de garantia do suprimento de gás ao consumidor, sendo uma contrapartida do produtor às garantias dadas pelo consumidor. Representa o compromisso do produtor em garantir uma receita mínima ao consumidor que realizou os investimentos para poder receber e utilizar o gás.

Todo o enlace contratual tem como objetivo o retorno dos investimentos realizados ao longo da cadeia produtiva, desde o produtor ao consumidor. Contudo, deve-se considerar as incertezas do mercado ao longo prazo, logo muitas vezes há a necessidade de flexibilização que cada agente requer para responder eficientemente as mudanças no ambiente comercial, não previstas na época de contratação. 


\section{ESTRUTURA DE CUSTOS DE USINAS TERMELÉTRICAS}

A informação sobre os custos de uma usina termelétrica incide na preparação da estratégia de participação no leilão, bem como analisa a competitividade do projeto proposto pelo agente. Com isso, o exame para representar esses parâmetros é feito na reprodução dos custos.

Num leilão de energia, a qualificação de um empreendimento, ou melhor, sua habilitação se baseia também em aspectos de sua viabilidade econômica frente aos agentes, Nesse sentido, promove-se a importância da estrutura de custos, composta por custos fixos e custos variáveis de operação. Além de outros parâmetros, tais como garantia física. A junção dessas variáveis representa um modelo para observar o retorno do investimento e a sua inserção no mercado. A caracterização desses parâmetros vai recair sobre o parâmetro primordial de análise de mercado o ICB (Índice de Custo Benefício).

\subsection{Custos Fixos}

Os custos fixos correspondem aos investimentos para instalação da capacidade da planta de geração e de implantação da infra-estrutura para o suprimento do combustível, além de despesas operacionais e outros encargos. Logo, sua caracterização é independente da quantidade de lotes ofertada, ou seja, uma etapa inicial na estruturação dos custos é de responsabilidade exclusiva do proponente vendedor e deverá abranger todos os componentes a que se destina a cobertura, dentre outros:

(i) custo e remuneração de investimento (taxa interna de retorno);

(ii) custos de conexão ao sistema de distribuição e transmissão;

(iii) custo de uso do sistema de transmissão e distribuição;

(iv) custos fixos de O\&M;

(v) custo decorrente do consumo de combustível e manutenção do empreendimento correspondente à declaração de inflexibilidade;

(vi) custos de seguro e garantias do empreendimento e compromissos financeiros do proponente vendedor;

(vii) tributos e encargos diretos e indiretos. 
No Custo fixo ( $\mathrm{R} \$ \mathrm{Ano}$ ), representa-se a receita requerida pelo investidor para cobrir o custo total de implantação do investimento. Nessa ótica ele é o responsável por alicerçar e fornecer a base ao empreendimento.

Atua no preço fixo, concomitantemente, $a$ inflexibilidade que estabelece a declaração de geração de uma usina eletroenergética, que se constitui numa restrição que leva à necessidade de geração mínima da usina a ser considerada, na otimização do uso dos recursos. É feito de acordo com o despacho da usina, no sistema "Take or Pay". Consiste numa condição para operação de geração, por meio da garantia do suprimento do combustível. Nesse aspecto, estabelece a relação de remunerar o produtor e explorador do combustível, visto que o sistema reduz a ação do empreendedor da geração que deve pagar pelo mesmo, declarando-se a inflexibilidade. O reajuste associado à parcela de inflexibilidade é feito de forma específica para o combustível.

Na cobertura dos custos fixos, há a parcela da receita fixa que será paga ao longo de toda a vida do contrato. A receita fixa compõe-se de duas parcelas, que estabelecem a relação do combustível e operacionalidade.

$$
R F=C F C+C F \quad(E q .4 .1)
$$

O Custo Fixo do Combustível (CFC) é parcela da Receita Fixa, destinada a cobrir o custo de combustível associado à Declaração de Inflexibilidade e será reajustada conforme regra aplicada à parcela do Custo Variável Unitário vinculada ao custo do combustível;

O Custo Fixo Operacional (CFO) é a parcela da Receita Fixa destinada a cobrir os demais custos fixos.

A caracterização da receita fixa se desdobra nos parâmetros operacionais, como custos de sistema de distribuição e transmissão, emolumentos sócio-ambientais e a parcela incidente sobre o combustível. Essa análise é feita de maneira proporcional pelo ONS.

Ao se observar, especificamente, o gás natural pode-se perceber que, caso não haja um equilíbrio bem executado no encadeamento exploração, produção e geração é possível chegar numa "inflação" de sua demanda. Nesse sentido, uma alternativa seria o mercado ininterruptível para assegurar o fornecimento, que faria com que a parcela não utilizada pelo empreendedor pudesse ser comercializada pelo próprio a terceiros, adequando racionalmente o perfil de risco associado ao abastecimento. 


\subsection{Custo Variável de Operação}

O Custo Variável de Operação (CVO) estabelece uma função do Custo Variável Unitário (CV) - custo associado ao valor total dos gastos operacionais variáveis pela quantidade de energia gerada, chegando a um valor base constante por energia produzida que estabelece o padrão. O CVO representa uma remuneração que será paga, somente, quando a termelétrica operar. Será um valor expresso em reais por megawatt-hora (R $\$ \mathrm{MWh})$, informado pelo proponente vendedor antes do início do leilão e que serve de base para definição da garantia física, necessário para cobrir todos os custos operacionais do empreendimento, exceto os já cobertos pela receita fixa.

Esse custo incide sobre o despacho da usina e o custo variável de O\&M. Trata-se, portanto, de uma variável aleatória que se estabelece em função de Custos Marginais de Operação (CMO), com base em simulações estáticas de 60 meses, utilizando uma amostra com 2000 cenários possíveis.

Ressalta-se também que dentro do próprio custo variável unitário, além da parcela de O\&M, há o custo variável do combustível, lembrando que esse custo recai sobre o combustível não pode ser confundido com o custo fixo de combustível, visto que aquele atende uma demanda contratual fixada, já este se estabelece em função da variabilidade de sua operação, relacionando a flexibilidade de demanda. Logo, pode-se entender que o CVO é mais amplo no sentido que além de se relacionar com o $\mathrm{CV}$, possui também o CMO.

De acordo com a EPE, tem-se

$$
C V=C c o m b+C O \& M \quad(E q .4 .2)
$$

Onde,

$O C V$ representa o Custo Variável Unitário em $\mathrm{R} \$ / \mathrm{MWh}$.

$O$ Ccomb é a parcela vinculada ao custo do combustível destinada à geração de energia flexível em R\$MWh.

E o $C O \& M$ que é a parcela do CV vinculada aos demais custos variáveis, informada em R $\$ / M W h$.

Concluindo, de forma geral, tem-se a função do Custo Variável Operacional como uma relação entre os custos citados na fórmula que segue.

$$
f(C V O) \rightarrow(C V, C M O) \quad(E q .4 .3)
$$


Para elucidar essa análise, há uma representação da variação dos custos ligados a alternância de preços do gás natural e outras fontes, feito pela EPE.

Numa consideração inicial em 2006, na portaria MME 305/2006, para cálculo base de custos de operação para fornecimento de dados para fins de determinação de parâmetros da termelétrica, como garantia física e custos operacionais, confeccionou-se a tabela 4.1 de custos de combustíveis que segue:

Tabela 4.1 - Preço médio dos combustíveis em 2006/7

\begin{tabular}{|c|c|c|c|c|c|}
\hline \multirow{2}{*}{$\begin{array}{c}\text { Taxa de } \\
\text { Câmbio } \\
(1) \\
\text { (R\$/US\$) }\end{array}$} & \multicolumn{5}{|c|}{ Preço médio dos combustíveis } \\
\hline & $\begin{array}{c}\text { GN (2) } \\
\text { (US\$/MMBTU) }\end{array}$ & $\begin{array}{c}\text { OD (3) } \\
\text { (US\$/gal) }\end{array}$ & $\begin{array}{c}\text { OC A-1 (4) } \\
\text { (US\$/bbl) }\end{array}$ & $\begin{array}{c}\text { OC B-1 (5) } \\
\text { (US\$/bbl) }\end{array}$ & $\begin{array}{c}\text { Carvão (6) } \\
\text { (US\$/ton) }\end{array}$ \\
\hline 2,1385 & 6,5553 & 1,7891 & 44,7959 & 46,2508 & 64,621 \\
\hline
\end{tabular}

Fonte: EPE Fonte: EPE - Nota: EPE-DEE-IT-001/2007

Notas:

(1) Valor médio da taxa de câmbio de janeiro de 2007 (Fonte: Sibacem PTAX800)

(2) Valor médio de fevereiro de 2006 a janeiro de 2007, referente ao "Henry Hub Natural Gas Spot Price" (Fonte : Platts).

(3) Valor médio de fevereiro de 2006 a janeiro de 2007, referente ao "N". 2 US Gulf Water Bone" (Fonte: Platts).

(4) Valor médio de fevereiro de 2006 a janeiro de 2007, referente ao "N". $63 \%$ US Gulf Water Bone" (Fonte : Platts).

(5) Valor médio de fevereiro de 2006 a janeiro de 2007 referente ao "No $61 \%$ US Gulf Water Bone" (Fonte : Platts).

(6) Valor médio de fevereiro de 2006 a janeiro de 2007, referente ao "Coal Price CIF ARA Month Ahead" (Fonte : Platts), convertido de US\$c/MWh para US\$/tonelada métrica considerando um PC $I=6000 \mathrm{Kcal} / \mathrm{kg}$ e o rendimento de 34\%, conforme metodologia usada no Platts ("Methodology and Specifications Guide - Coal”, march/2007).

Lembrando que $O D$ representa óleo diesel, $O C$ óleo combustível, A-1 e B-1 representam especificações distintas do óleo combustível quanto a sua densidade, refinamento e concentração de enxofre.

Numa análise mais recente, para os leilões de energia em 2008, para fins de compra de energia elétrica, mais especificamente os leilões A-3 e A-5 revelam a mudança de valoração das fontes que concorre diretamente na taxa cambial, como nas tabelas 4.2 e 4.3 : 
Tabela 4.2 - Preço médio dos combustíveis em 2008 (Leilão A-3)

\begin{tabular}{|c|c|c|c|c|c|}
\hline \multirow{2}{*}{$\begin{array}{c}\text { Taxa de } \\
\text { Câmbio } \\
(1)\end{array}$} & \multicolumn{5}{|c|}{ Preço médio dos combustíveis } \\
\cline { 2 - 6 } & $\begin{array}{c}\text { GN (2) } \\
\text { (R\$/US\$) }\end{array}$ & $\begin{array}{c}\text { OD (3) } \\
\text { (US\$/MMBTU) }\end{array}$ & $\begin{array}{c}\text { OC A-1 (4) } \\
\text { (US } \$ / g a l)\end{array}$ & $\begin{array}{c}\text { OC B-1 (5) } \\
\text { (US } \$ / \text { bbl) }\end{array}$ & $\begin{array}{c}\text { Carvão (6) } \\
\text { (US } \$ / \text { ton) }\end{array}$ \\
\hline 1,7860 & 6,970 & 2,0084 & 53,09 & 55,62 & 88,75 \\
\hline
\end{tabular}

Fonte: EPE - Nota: EPE-DEE-IT-001/2008

Na tabela 4.3 tem-se o preço das fontes no leilão A-5, realizados no mesmo ano.

Tabela 4.3 - Preço médio dos combustíveis em 2008 (Leilão A-5)

\begin{tabular}{|c|c|c|c|c|c|}
\hline \multirow{2}{*}{$\begin{array}{c}\text { Taxa de } \\
\text { Câmbio } \\
(7)\end{array}$} & $\begin{array}{c}\text { Preço médio dos combustíveis } \\
\text { GN (8) } \\
\text { (R\$/US\$) }\end{array}$ & $\begin{array}{c}\text { OD (9) } \\
\text { (US\$/MMBTU) }\end{array}$ & $\begin{array}{c}\text { OC A-1 (10) } \\
\text { (US } \$ / \text { gal) }\end{array}$ & $\begin{array}{c}\text { OC B-1 (11) } \\
\text { (US } \$ / \text { bbl) }\end{array}$ & $\begin{array}{c}\text { Carvão } \\
(12) \\
(\text { US } \$ / \text { ton) }\end{array}$ \\
\hline 1,7743 & 7,087 & 2,0903 & 55,08 & 58,54 & 93,54 \\
\hline
\end{tabular}

Fonte: EPE - Nota: EPE-DEE-IT-001/2008 -

Notas:

(1) Valor médio da taxa de câmbio diário de dezembro de 2007, da venda do dólar dos Estados Unidos (Fonte: Sibacem PTAX800)

(2) Valor da média da cotação média diária de janeiro a dezembro de 20007 (Fonte: Platts; código IGBBLO0). Este valor também será utilizado para gás natural regaseificado.

(3) Valor da média da cotação média diária de janeiro a dezembro de 2007, referente ao "No 2 US Gulf Water Bone" (Fonte: Platts; código POAEE00).

(4) Valor da média da cotação média diária de janeiro a dezembro de 2007, referente ao " $N^{o}$. 6 $3 \%$ US Gulf Water Bone" (Fonte: Platts; código PUAFZ00).

(5) Valor da média da cotação média diária de janeiro a dezembro de 2007, referente ao " $N^{o} .6$ $1 \%$ US Gulf Water Bone" (Fonte: Platts; código PUAAIOO).

(6) Valor da média da cotação semanal de 5 de janeiro de 2007 a 28 de dezembro de 2007, referente ao "Coal Price CIF ARA 6000k<1S NAR 90" (Fonte: Platts; código CSABG10).

(7) Valor médio da taxa de câmbio diário de janeiro de 2008, da venda do dólar dos Estados Unidos (Fonte: Sibacem PTAX800)

(8) Valor da média da cotação média diária de fevereiro de 2007 a janeiro de 2008 (Fonte: Platts; código IGBBLO0). Este valor também será utilizado para gás natural regaseificado.

(9) Valor da média da cotação média diária de fevereiro de 2007 a janeiro de 2008, referente ao " $N^{o} .2$ US Gulf Water Bone" (Fonte: Platts; código POAEEO0).

(10) Valor da média da cotação média diária de fevereiro de 2007 a janeiro de 2008, referente ao " $N^{o}$. $63 \%$ US Gulf Water Bone" (Fonte: Platts; código PUAFZ00).

(11) Valor da média da cotação média diária de fevereiro de 2007 a janeiro de 2008 , referente ao " $N^{o}$. $61 \%$ US Gulf Water Bone" (Fonte: Platts; código PUAAIOO).

(12) Valor da média da cotação semanal de 02 de fevereiro de 2007 a 25 de janeiro de 2008, referente ao "Coal Price CIF ARA 6000k<1S NAR 90" (Fonte: Platts; código CSABG10). 
Uma comparação a ser estabelecida na figura 4.1, realizando a conversão para a quantificação do preço do combustível em MWh. O gás natural possui variações mais homogêneas de US\$ 49,29 /MWh para o preço base de 2007, chegando a valor de US\$ /MWh 53,49 /MWh para o leilão A-5 com uma variação de 8,5\% no seu preço. Quanto ao óleo diesel seu preço varia de US\$ 117,76/MWh para o preço final de US\$ 137,70/MWh para o período determinado (variação de $16,93 \%$ ). E, finalmente, para o carvão seu preço passa de US\$ 38,77/MWh para US\$ 56,12/MWh com a oscilação maior em questão, dentro dessa comparação, de 44,75\%. Ou seja, a ponderação sobre custo por combustível tal qual em energia revela a precificação do gás natural como uma fonte primordial para análise da expansão térmica.

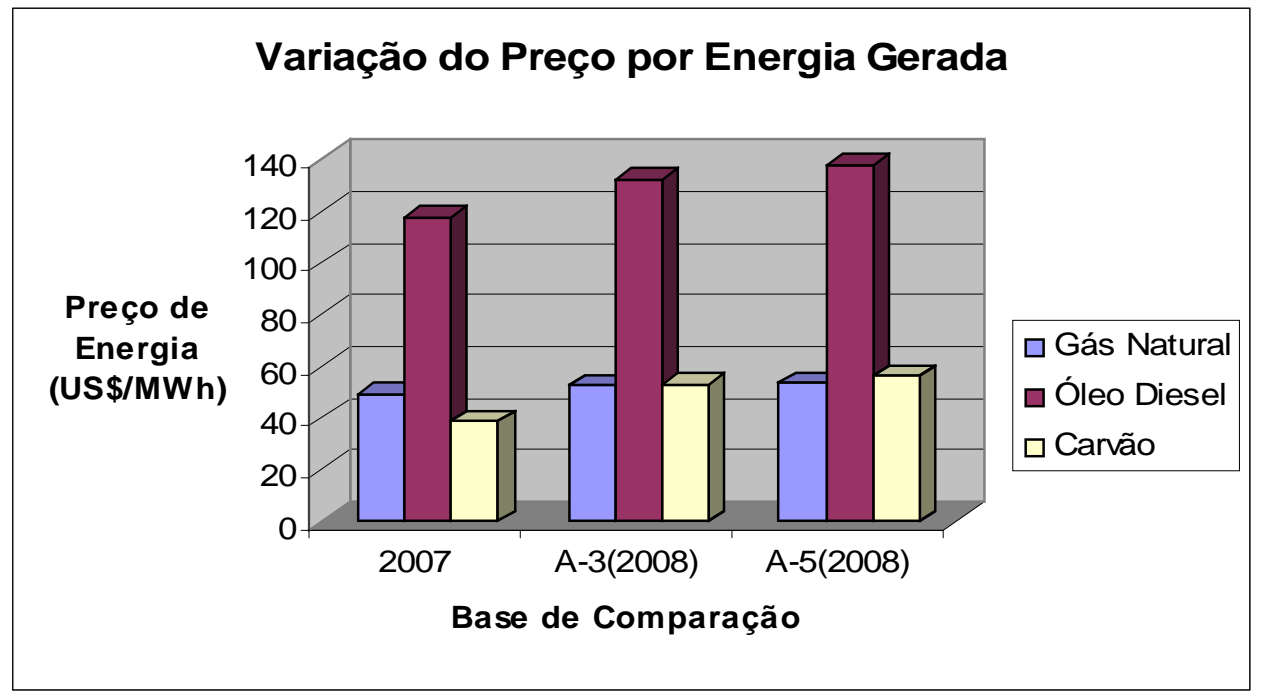

Fig. 4.1 - Comparação de preço para cada combustível pela sua energia gerada com base em 2007 e nos leilões A-3 e A-5 de 2008

Fonte: EPE - Nota: EPE-DEE-IT-001/2008

Nota:

Conversão utilizada: Gás Natural (consumo - 7,55 MMBTU/MWh); Óleo Diesel (consumo - 0,25 l/MWh) e Carvão (consumo - 0,60 ton/MWh).

O carvão considerado apresentou valores de preço por energia próxima ao gás natural, todavia o que pesa sobre o carvão é justamente o impacto ambiental causado na emissão de de plouentes como o gás carbônico e de compostos de enxofre. Esses são grandes contribuintes para o efeito estufa e para chuvas ácidas. Logo, mesmo com um preço competitivo o carvão passa por um "embargo ambiental" abrindo espaço para o gás natural como um recurso não poluente que, apesar de emitir na sua combustão gás carbônico não o faz na mesma proporção do carvão. Já quanto ao óleo diesel, recai sobre ele o grande impacto ambiental semelhante ao carvão por ser um derivado de petróleo considerado poluente atmosférico. 
Um exemplo para a discussão dos custos dos combustíveis está mais especificamente nos dados oferecidos para fevereiro de 2008, em que sua caracterização de empreendimentos térmicos em função da geração de energia foi basicamente a óleo diesel, mas desse resultado pode-se perceber a diferença de custos entre gás natural e óleo. Como se percebe na tabela 4.4 da CCEE que segue:

Tabela 4.4 - Empreendimentos e Custos de Combustiveis para início em 2008

\begin{tabular}{|c|c|c|c|c|}
\hline $\begin{array}{c}\text { Empreendimento } \\
\text { Térmico }\end{array}$ & $\begin{array}{c}\text { Tipo de } \\
\text { Combustível }\end{array}$ & $\begin{array}{c}\text { Custo do } \\
\text { Combustível } \\
\text { (R\$/MWh) } \\
\text { Dez/05 }\end{array}$ & \begin{tabular}{|c|} 
Custo do \\
Combustível \\
(R\$/MWh) \\
Fev/07 \\
\end{tabular} & $\begin{array}{c}\text { Custo do } \\
\text { Combustível } \\
\text { (R\$/MWh) } \\
\text { Fev/08 }\end{array}$ \\
\hline Xavante Aruanã & Óleo Diesel & 840,99 & 624,6 & 749,33 \\
\hline Daia & Óleo Diesel & 580,01 & 430,8 & 516,79 \\
\hline Jaguari & Óleo Diesel & 532,69 & 395,7 & 474,63 \\
\hline Pecem & Óleo Diesel & 532,69 & 395,7 & 474,63 \\
\hline Aracati & Óleo Diesel & 532,69 & 395,7 & 474,63 \\
\hline Baturité & Óleo Diesel & 532,69 & 395,7 & 474,63 \\
\hline Caucaia & Óleo Diesel & 532,69 & 395,7 & 474,63 \\
\hline Crato & Óleo Diesel & 532,69 & 395,7 & 474,63 \\
\hline Iguatu & Óleo Diesel & 532,69 & 395,7 & 474,63 \\
\hline Juazeiro do Norte & Óleo Diesel & 532,69 & 395,7 & 474,63 \\
\hline Campo Maior & Óleo Diesel & 532,69 & 395,7 & 474,63 \\
\hline Marambaia & Óleo Diesel & 532,69 & 395,7 & 474,63 \\
\hline Nazária & Óleo Diesel & 532,69 & 395,7 & 474,63 \\
\hline Altos & Óleo Diesel & 532,69 & 395,7 & 474,63 \\
\hline PIE-RP & Biomassa & - & - & - \\
\hline Termorio & Gás Natural & 98,74 & 94,33 & 89,18 \\
\hline Interlagos & Biomassa & - & - & - \\
\hline COCAL & Biomassa & - & - & - \\
\hline Quirinópolis & Biomassa & - & - & - \\
\hline
\end{tabular}

Fonte: CCEE (1 ${ }^{\circ}$ Leilão de Energia Nova - 2008-T15)

Com base na tabela acima, confeccionou-se a figura 4.2 em que pondera o custo médio do óleo diesel e o gás natural. Isso demonstra a grande discrepância entre os custos, que apesar de ser um caso específico para a Termorio (gás natural) pode ser ampliada para uma visão mais geral da expansão térmica a base de gás natural. Pois o valor onerado de custo operacional de combustível reflete diretamente em outros parâmetros de comercialização do leilão. E apesar da sensibilização do mercado, tem-se que a garantia da menor flutuação possível para um recurso viabiliza uma maior inserção de mercado e competitividade. 


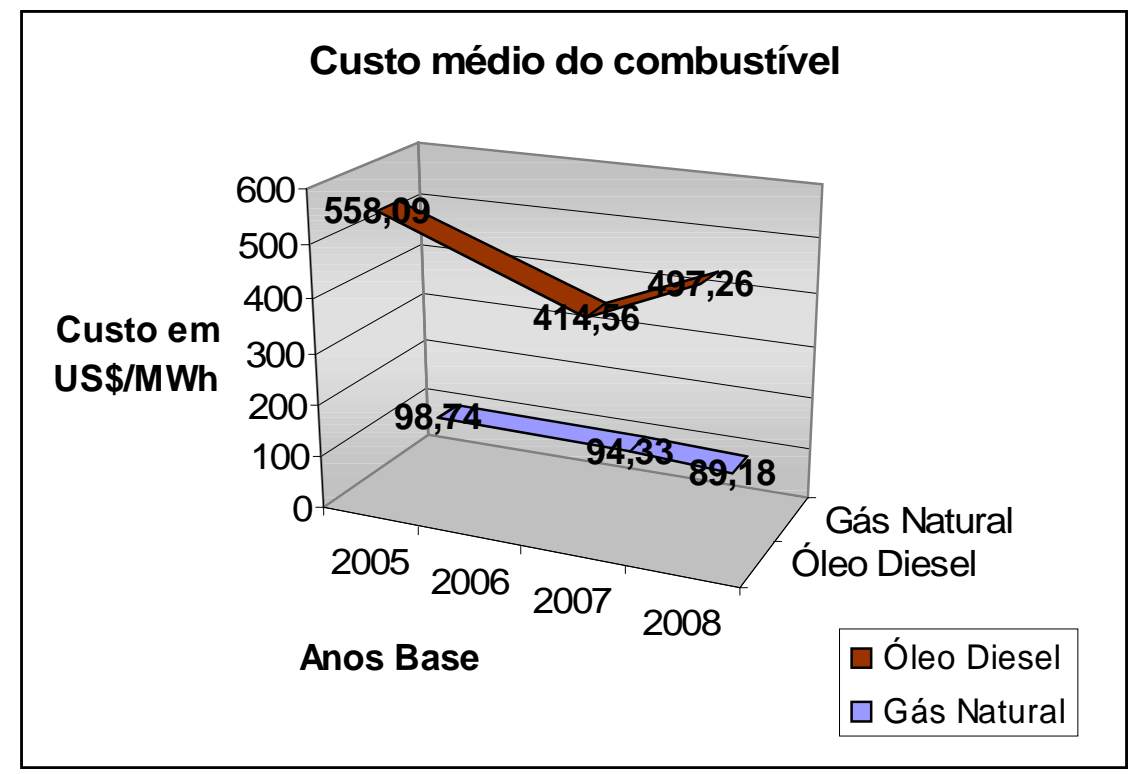

Fig. 4.2 - Comparação do Custo de Combustível no em início em 2008

Deve estar claro que há diferença em analisar o preço do combustível e o custo do combustível, isso se demonstra pela distinção de valores. O preço está associado a conversão específica, utilizando apenas o consumo específico, ou seja, sua eficiência energética. Já ao ponderar o custo está incluso diversos entes, como a taxação (ICMS, PIS, Cofins e CPMF), além de outros fatores da infra-estrutura de transporte e distribuição do combustível agregando um alto valor final ao combustível.

\subsection{Garantia Física}

A garantia física determina a quantidade de energia que poderá ser comercializada pela termelétrica, considerando as informações declaradas pelos agentes termelétricos, tais como:

(i) Potência efetiva - instalada na usina;

(ii) Fator de capacidade máximo (FCMax) - máximo percentual da potência instalada disponível para geração (sem considerar a manutenção);

(iii) Índices de indisponibilidade;

(iv) Inflexibilidade e

(v) Geração termelétrica total do sistema.

A Garantia Física é calculada pela a EPE, com base em parâmetros pré-estabelecidos. Representa em termos práticos a Energia Assegurada em megawatts-médios.

A metodologia de cálculo adotada no cálculo dos leilões corresponde a um dado critério de garantia de suprimento. Esta energia pode então ser rateada entre todos os empreendimentos 
de geração que constituem o sistema. Este procedimento tem por objetivo garantir efetivamente o lastro físico daqueles empreendimentos com vistas à comercialização de energia via contratos.

Pode-se dizer que os passos a serem seguidos podem ser descritos da seguinte forma (numa visão geral adota-se o método Sistema Interligado Nacional):

I. Determinação da oferta total de energia física, correspondente à garantia física do sistema interligado (Norte, Nordeste, Sudeste/Centro-Oeste e Sul), obtida por simulação estática da operação do sistema hidrotérmico empregando-se o modelo NEWAVE. No processo iterativo de ajuste da oferta total, mantém-se uma proporção fixa entre as ofertas dos subsistemas Sul e Sudeste/Centro-Oeste, assim como as dos Norte e Nordeste, havendo, no entanto, uma variação livre da oferta conjunta e da proporção relativa entre estes dois grandes sistemas regionais. O processo é considerado convergido quando, no mínimo, um subsistema de cada sistema regional atinge o risco de 5\%, admitida uma tolerância, de acordo com o critério de garantia de suprimento estabelecido pelo Conselho Nacional de Políticas Energéticas - CNPE.

II. Rateio da garantia física do SIN ou oferta total em dois grandes blocos de energia, oferta hidráulica (EH) e oferta térmica (ET), que são obtidos multiplicando-se a oferta total por um Fator Hidro (FH) e um Fator Térmico (FT). Estes fatores correspondem à participação relativa das gerações hidráulica e térmica na geração total e são calculados com base em uma ponderação pelo custo marginal de operação (CMO) das gerações hidráulicas $(\mathrm{GH})$ e térmicas (GT) que são obtidas na simulação com o modelo NEWAVE.

III. Rateio da oferta hidráulica do conjunto das usinas hidrelétricas da configuração, ou oferta hidráulica $(\mathrm{EH})$, é feito proporcionalmente às energias firmes das usinas hidráulicas obtidas por simulação a usinas individualizadas do sistema integrado puramente hidrelétrico, utilizando séries de vazões históricas e tendo como referência o período crítico do sistema interligado, sendo limitada ao valor da sua disponibilidade máxima de geração contínua.

IV. Rateio da oferta térmica do conjunto das usinas termelétricas da configuração, é feito por usina termelétrica e está limitada ao valor de sua disponibilidade máxima de geração contínua, sendo o excedente distribuído entre as demais térmicas da configuração na proporção de suas garantias físicas, calculadas no passo anterior. No caso de usinas termelétricas, esta garantia física está condicionada ainda à apresentação de contrato firme de suprimento de combustível. Este procedimento tem por objetivo 
garantir efetivamente o lastro físico dos empreendimentos de geração, com vistas a comercialização de energia via contratos.

Há critérios que devem ser estabelecidos para configuração de referência que levam em conta a proporcionalidade da carga, ou seja, sua distribuição nos subsistemas. Como no caso em que se adota a previsão do EPE em 2009 de acordo com o plano decenal de energia.

Tabela 4.5 - Proporcionalidade da Carga

\begin{tabular}{|c|c|c|c|c|c|}
\hline \multicolumn{6}{|c|}{ Carga de Energia do Plano Decenal - Ano 2009 - (MWmed) } \\
\hline Sudeste/Centro-Oeste & Sul & SE/CO-S & Nordeste & Norte & NE - N \\
\hline 35.333 & 9.168 & 44.501 & 8.144 & 3.965 & $\mathbf{1 2 . 1 0 9}$ \\
\hline $79 \%$ & $21 \%$ & - & $67 \%$ & $33 \%$ & - \\
\hline
\end{tabular}

Fonte: EPE - Projeção de Carga, 2007

Outros fatores são utilizados como bases de referência, tais como:

- Parâmetros de usinas termelétricas que representam os custos variáveis para todas as UTE do sistema existentes;

- Limites de transmissão entre subsistemas que são limites de transferência de energia adequados ao parque hidrotérmico da configuração com usinas novas;

- Volume mínimo e Restrições Operativas Hidráulicas para usinas em operação;

- Importação e Função Custo de Déficit de Energia estabelecido pela ANEEL;

- Históricos de Vazões Consultivos;

- Critério de Rateio e Definição do Bloco Hidráulico e Térmico.

Para o cálculo efetivo da garantia física, as usinas termo-elétricas são agrupadas em blocos cujas características são semelhantes dependendo do custo operacional associado, da potência gerada e principalmente do combustível utilizado. Essa relação favorece a sinergia do sistema. Em princípio, quanto mais usinas estiverem na configuração maior será esta sinergia e, portanto, maior a energia assegurada total do sistema.

A configuração térmica possui parâmetros já mencionados que entram diretamente no cálculo da garantia física, os que constituem a Indisponibilidade forçada (TEIF) e Programada (IP) que representam taxas indicadoras da medida de probabilidade de ocorrência de um desligamento forçado ou programado de operação da unidade com potência limitada. Elas refletem a limitação à geração. Há também o Fator de Capacidade Máxima (FCMax) que representa o percentual médio que a usina consegue gerar continuamente. E finalmente a 
própria Potência Efetiva (PotEfte) instalada na usina. Com isso, com a fórmula que relaciona essas variáveis tem-se a caracterização da Disponibilidade Energética Máxima (Dispmax) do empreendimento que por meio da média tomada a cada mês e da simulação desses fatores já designados, finalmente chega-se a Garantia Física $(\boldsymbol{G F})$. Como se evidencia nas seguintes equações:

$$
\text { Disp } \max =\text { PotEfte } x \text { FC } \max x(1-T E I F) x(1-I P)
$$

$\mathrm{E}$,finalmente, na média tomada a cada mês, chega-se a equação característica:

$$
\boldsymbol{G F}=\sum_{n=1}^{12} \text { Disp } \max / \mathbf{1 2} \quad(E q .4 .5)
$$

\section{4 Índice de Custo Benefício (ICB)}

O índice é um indicador que permite estabelecer a comparação e competitividade do custo de geração dos diferentes tipos de empreendimentos de geração termelétrica. Quanto menor o ICB, menor o custo de geração e, por conseguinte, mais competitiva é a termelétrica. $\mathrm{Na}$ fase anterior ao leilão, os agentes recebem o valor do teto máximo do ICB que será aceito pelo governo, ou seja, o preço em que será aberto o leilão. Consiste em valor, expresso em reais por megawatt-hora (R\$MWh).

A relação entre Receita Fixa e Custo Variável de Operação na formação do ICB relaciona-se de forma que um custo fixo baixo permite suportar um maior custo variável sem afetar significativamente o ICB. Logo é reforçado o papel de complementação das termelétricas, com base na minimização dos custos fixos e na flexibilização de custos variáveis para a garantia da geração termelétrica.

Assim, o ICB é definido como a razão entre o custo total (fixos, variáveis e de curto prazo) e o seu benefício energético (energia assegurada).

$$
\boldsymbol{I C B}=\frac{\text { Custos Fixos }+E(\text { Custos Variáveis })+E(\text { Custos de Curto Prazo })}{\text { Garantia Física }}
$$




\subsubsection{Cálculo do ICB}

Na caracterização do cálculo do ICB, há outro parâmetro importante na análise de viabilidade e retorno dos investimentos que são os valores esperados de custo econômico de curto prazo e custo de operação:

O Valor Esperado do Custo Econômico de Curto Prazo (CEC) é um valor, expresso em Reais por ano (R\$ano), correspondente ao custo econômico no mercado de curto prazo, resultante das diferenças mensais apuradas entre o despacho efetivo da usina e sua garantia física, para este efeito considerado totalmente contratado. Essa diferença que será posta na Compra e Venda na CCEE.

Corresponde ao valor esperado acumulado das liquidações do mercado de curto prazo, feitas com base no Custo Marginal de Operação - CMO. Esse valor também é função do nível de inflexibilidade do despacho da usina e do Custo Variável Unitário;

A parcela de Valor Esperado de Custo de Operação (COP) é função dos itens de do nível de inflexibilidade da usina, tais como contrato de combustível e custos variáveis de O\&M, declarado pelo empreendedor, o qual determina a condição de despacho em função dos CMOs futuros. Vale ressaltar que nesse custo incide também o cenário hidrológico para cada mês, por meio de uma análise mensal sintética de 2.000 amostras simuladas - operada pelo software NEWAVE. Em resumo, o COP representa a parcela de custos variáveis operacionais.

Tanto o COP, quanto o CEC observam os valores calculados com base numa mesma amostra de CMO.

Com todos os parâmetros já devidamente esclarecidos, o cálculo do ICB segue a seguinte formatação:

(i) Com base nos mesmos dados informados pelos agentes para o cálculo da garantia física, a EPE calculará e disponibilizará, para conhecimento dos proponentes vendedores, os valores de custo marginal de operação que serviram de base para cálculo do COP e do CEC, cuja formulação matemática é descrita a seguir:

$$
C O P=C V \times(\text { Ger }- \text { Inflex }) \times h \quad(E q .4 .7)
$$

Onde,

$C V$ representa Custo Variável Unitário;

Ger representa a parcela gerada em MW médios e 
$h$ representa às horas médias mensais de apuração.

(ii) Para o cálculo anual basta multiplicar o resultado por 12. O COP é calculado para cada cenário e para cada mês. Da seguinte forma o CEC é representado:

$$
C E C=\text { CMO' }^{\prime} *(\text { G.Física }- \text { Ger }) x h \quad(E q .4 .8)
$$

Onde,

$C M O$ representa o custo marginal de operação

G.Física representa a garantia física

O cálculo do CEC é feito de forma similar ao do COP, pois considera a usina como um todo, para cada mês e para cenários possíveis. Para o cálculo do ICB é utilizado como critério de seleção dos projetos térmicos, já inclui-se a quantidade de lotes ofertada $(Q L)$, que apresentam os menores valores, utiliza-se a fórmula abaixo:

$$
I C B=\left[\frac{R F}{(Q L * h)}\right]+\left[\frac{(C O P+C E C)}{(G F * h)}\right]
$$

Em um empreendimento em que apenas uma fração (x) de sua Energia Assegurada (Garantia Física) seja destinada ao ACR, sendo o restante reservado para uso próprio ou para comercialização no ACL, para efeito de cálculo do ICB, representa-se o conjunto formado pelos custos operacionais e o de recuperação de capital, COP e CEC, respectivamente, relacionando ao total da garantia física. Portanto, chega-se a uma expressão que varia com a fração da energia e outra invariável.

Com base nessa explanação, a ótica do leilão reescreve a equação anterior elencando a parcela (x) da Energia Assegurada a se estabelecer na contratação por disponibilidade no leilão.

$$
I C B=\frac{x R F}{x}+\frac{(C O P+C E C)}{G F} \quad(E q .4 .10)
$$

Considerando: $\quad K=\underline{(C O P+C E C)} \quad$ (Eq. 4.11)

$G F$ 
E a relação de quantidades de lotes $(\mathrm{QL})$ e a relação ao longo do ano (8760h). É possível reescrever a equação a ser caracterizada pelo leilão.

$$
I C B=\frac{R F}{8760 \cdot Q L}+K
$$

Onde,

$R F$ é a Receita Fixa requerida pelo empreendedor, relativa à quantidade de lotes (QL) ofertada para o ACR, em R $\$ / a n o$;

QLé a Quantidade de Lotes (de no mínimo 1 MWmédio) ofertada para o ACR limitada a GF (igual a x.GF);

$K$ é a parcela invariante do índice, em $\mathrm{R} \$ / \mathrm{MWh}$, destinada à cobertura dos custos variáveis de operação e custos econômicos no mercado de curto prazo, calculada para o empreendimento como um todo (válido para qualquer valor de $\mathrm{x}$ ), na realização do leilão.

Durante o leilão, o preço será quantificado com base nessa regra, os valores base da Receita Fixa e da Quantidade de lotes ofertados e o valor da parcela $K$ relativa ao empreendimento. Portanto a comparação de projetos termelétricos para qualquer valor da parcela $(x)$ define um percentual mínimo na comercialização no ambiente controlado.

Dentro do procedimento do cálculo do ICB se analisa o despacho e a inflexibilidade declarada que pode ser considerada de acordo com:

(i) Razões energéticas - quando o CMO (Custo Marginal de Operação) for maior que o seu CV (Custo Variável Unitário);

(ii) Razões elétricas - quando faz jus a Encargos por Serviços ao Sistema, tais como a necessidade do sistema de transmissão.

A situação mais comum é a de despacho por razões energéticas, pois quando o CMO é superior ao CV, a usina gera em MW médios igual a sua disponibilidade máxima mensal. Já quando se inverte a situação, ou seja, o CMO é inferior ao CV a usina gera equivalente a sua inflexibilidade. 


\section{ESTUDO DE CASO}

\subsection{Objetivo}

Esta análise tem por objetivo verificar os conceitos propostos no capítulo anterior para avaliar um estudo realizado pela ELETRONORTE (Nota Técnica EPEE - 03/2007. Atratividade Econômica das UTE Termonorte I e II após a Interligação do Sistema Acre-Rondônia ao SIN da Gerência de Planejamento Energético, elaborada em fevereiro de 2007) de atratividade econômica da UTE Termonorte II para a interligação no Sistema Interligado Nacional (SIN).

\subsection{Situação Proposta}

A região Norte, no fim dos anos 90 apresentou um intenso crescimento de consumo de energia elétrica, devido ao programa de interligação de cidades isoladas do interior de transmissão da ELETRONORTE em Rondônia.

Com a meta de ampliação da capacidade geradora instalada neste sistema para evitar racionamento de energia, a ELETRONORTE assinou um contrato num planejamento de longo prazo de 20 anos com o Produtor Independente de Energia (PIE Termonorte Ltda.) para a implantação de uma termelétrica de 345 MW (Termonorte II).

Anteriormente, a empresa brasileira já havia contratado, em caráter emergencial, outra UTE do mesmo PIE, a Termonorte I.

A Termonorte II funciona em ciclo combinado, cuja finalização das etapas de instalação foi concluída em setembro de 2003. Constitui-se de três turbinas a gás e uma turbina a vapor.

Na contratação da UTE Termonorte II, a Petrobrás sinalizava na data de julho de 2003 a chegada do gás natural de Urucu em Porto Velho. Como este fato não se concretizou, a referida térmica está operando com combustível líquido de óleo PTE (óleo leve produzido somente na Refinaria de Manaus).

A Petrobrás propôs à ELETRONORTE a celebração de contrato de fornecimento de gás natural para a geração termelétrica na região, em Porto Velho. 
A geração termelétrica com gás natural sempre foi a mais atrativa, quando analisada no sistema isolado. Em 2006 foi licitada uma interligação Rondônia e Mato-Grosso que integrará os sistemas de Acre e Rondônia. Após a interligação, o Sistema Acre-Rondônia terá a sua contabilização e liquidação realizada no âmbito da Câmara de Comercialização de Energia Elétrica - CCEE para a participação nos Leilões de Energia Nova.

Nesse sentido, torna-se primordial avaliar a atratividade econômica da UTE Termonorte II para dar subsídios a decisões de inserção dentro dos leilões de energia.

\subsection{Base dos Estudos}

Foram estudados dois cenários para UTE Termonorte II, distintos quanto ao tipo de combustível utilizado.

No primeiro caso, tem-se o óleo PTE utilizado pela Termonorte II. Com a possibilidade da chegada do gás natural em Rondônia, pelo gasoduto Urucu-Porto Velho tem-se o segundo cenário para esse combustível.

Os contratos vigentes de suprimento com o PIE foram considerados em cada caso.

\subsubsection{Impostos}

Os impostos considerados foram os seguintes: ICMS (25\%), PIS (1,65\%), Cofins $(7,60 \%)$.

\subsubsection{Dados para Geração a Óleo PTE na Termonorte II}

As premissas consideradas foram:

(I) Dados da Usina:

- Potência Assegurada: 340 MW;

- Disponibilidade: 306 MW (90\% da Potência Assegurada);

- Garantia Física: 186,23 MW médios (cálculo na seção 5.4);

- Inflexibilidade: zero;

- Consumo Específico: 200 litros/MWh (ciclo combinado e a plena carga);

- FCMáx: $90 \%$. 
(II) Dados do Contrato com o PIE:

- Prazo do contrato: 20 anos;

- Energia Assegurada Contratual: 289 MW médios (85\% da Potência Assegurada);

- Preço da Geração: R\$ 63,16/MWh

- Remuneração da Receita Fixa, com geração até 85\%: R\$ 54,87/MWh;

- Preço Suplementar de Energia pela utilização do combustível óleo PTE: R\$ 8,29/MWh

(III) Combustível:

- Tipo: Óleo PTE;

- Preço: R \$ 2,1117/ litro (Nota Técnica n. 009/2008-SRG/ANEEL - Previsão Eletrobrás 2008 - com impostos)

(IV) Custo Variável:

- Parcela do Combustível: R\$ 422,34/MWh;

- Parcela suplementar do contrato PIE: R\$ 8,29/ MWh

- Custo Variável Total: R\$ 430,63 / MWh.

(V) Receita Fixa:

- Parcela Anual do pagamento do contrato com o PIE com geração a 85\%: R\$138,91 milhões/ano;

- Tarifa pelo Uso do Sistema de Transmissão Anual - TUST (um encargo legal do setor elétrico brasileiro que incide sobre os consumidores conectados aos sistemas elétricos das concessionárias de transmissão):

- Subsistema SE/CO: R\$ 12,00/kW (mês)

- Total: R \$ 48,96 milhões/ano

- Receita Fixa Total: $\mathrm{R} \$ 187,87$ milhões /ano

\subsubsection{Dados para Geração a Gás Natural na Termonorte II}

(I) Dados da Usina:

- Potência Assegurada: 345 MW; 
- Disponibilidade: 310,5 MW (90\% da Potência Assegurada);

- Garantia Física: 311,21 MW médios (cálculo na seção 5.4) ;

- Inflexibilidade: 276 MW (80\% da Potência Assegurada);

- Consumo Específico: 7,148 BTU/kWh;

- FCMáx: $90 \%$.

(II) Dados do Contrato com o PIE:

- Prazo do contrato: 20 anos;

- Energia Assegurada Contratual: 293,25 MW médios (85\% da Potência Assegurada);

- Preço da Geração: R \$60,357/MWh

- Remuneração da Receita Fixa, com geração até 80\%: R\$ 54,87/MWh;

- Remuneração da Receita Variável (Geração - Excedente acima de 80\%): R\$ 5,487/MWh.

(III) Dados do Contrato com a distribuidora BR (ainda não firmado)

- Prazo do Contrato: 20 anos;

- Volume Contratado: 1,65 milhões $\mathrm{m}^{3} / \mathrm{dia}$

- "Ship or Pay": $100 \%$ do volume contratado ou 1,65 milhões m³/dia

- "Take or Pay": 75\% do volume contratado ou 1,24 milhões $\mathrm{m}^{3} / \mathrm{dia}$

(IV) Combustível:

- Tipo: Gás Natural;

- Preço: R \$ 6,2453 milhões BTU (Eletrobrás - com impostos para o câmbio de U\$2,13);

(IV) Custo Variável:

- Parcela do Combustível (BR): R\$ 44,64 /MWh;

- Parcela suplementar do contrato PIE: R \$ 54,87/ MWh

- Custo Variável Total: R \$ 99,51/ MWh.

(V) Receita Fixa:

- Parcela da BR (em um ano): 
- "Ship or Pay": R\$ 331,11 milhões/ano;

- "Take or Pay": R\$ 82,62 milhões/ano;

- Parcela da BR: R\$ 413,73 milhões/ano;

- Parcela do PIE (em um ano): 132,66 milhões/ano.

- Tarifa pelo Uso do Sistema de Transmissão Anual - TUST

- Subsistema SE/CO: R \$ 12,00 kWh mês

- Total: R \$49,68 milhões/ano

- Receita Fixa Total: $\mathrm{R} \$ 596,07$ milhões/ano

\subsection{Estudos Realizados}

\subsubsection{Cálculo da Garantia Física para a Termonorte II}

O cálculo da garantia física das usinas termelétricas e hidrelétricas é feito considerando a configuração estática do SIN como foi apresentado na seção 4.3.

$\mathrm{Na}$ análise em questão, sabe-se que a garantia física depende diretamente do valor estabelecido para o seu custo variável, portanto foi elaborada uma análise paramétrica para o cálculo da garantia física para diversos custos variáveis. Assim, foram determinados valores de geração representativos que possibilitam determinar a garantia física com precisão aceitável para qualquer custo que se levante.

Para diversos valores de custo variável, obteve-se a curva correspondente na figura 5.1.

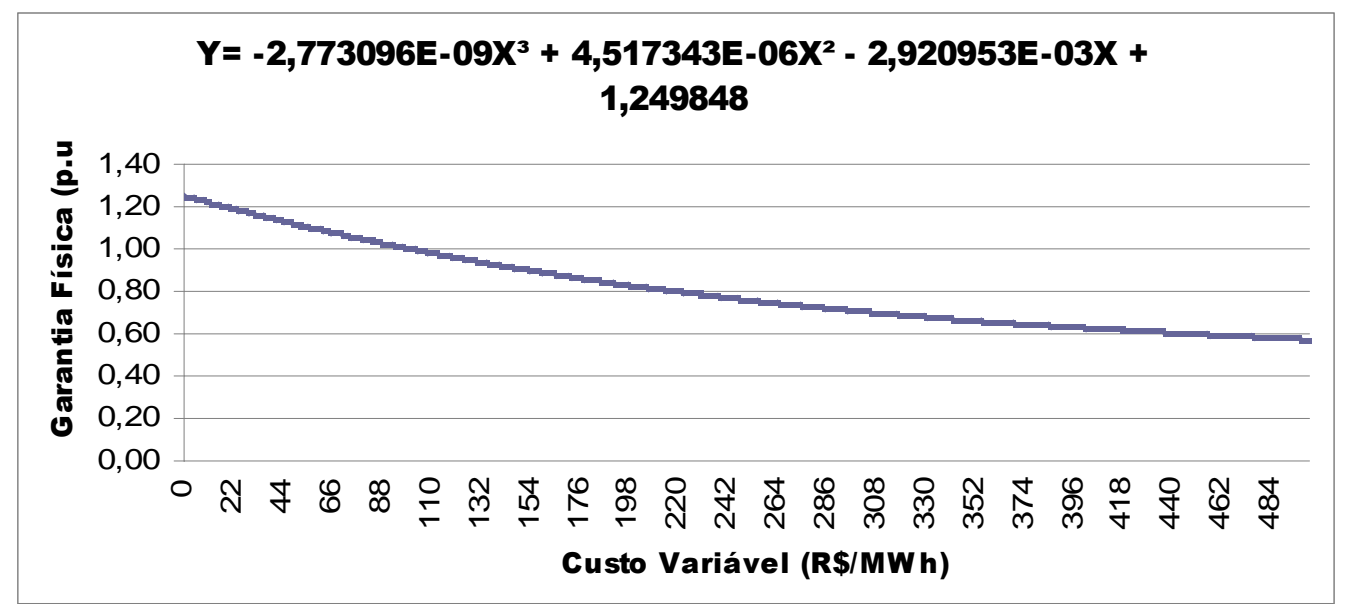

Fig. 5.1 - Curva Característica para Cálculo da Garantia Física

Essa curva foi obtida considerando-se a potência instalada da UTE de 340 MW e FCMax de 90,25\%. Com o objetivo de tornar a curva independente da potência instalada, já que a mesma depende do tipo de combustível, optou-se por expressá-la em valor unitário (p.u.). 
Deste modo é possível determinar, a partir da equação a seguir, a garantia física para quaisquer potência instalada, custo variável e fator de capacidade máximo.

$$
G F=\operatorname{Potência}(U T E) \frac{p . u . \times F C \max }{90,25 \%} \quad \text { (Eq. 5.1) }
$$

Onde,

p.u. = valor unitário para a Garantia Física obtido da figura 5.1 a partir do Custo Variável da UTE;

FCMax $=$ Fator de Capacidade Máxima da UTE (\%);

Potência $($ UTE $)=$ Potência Instalada da UTE (MW).

Para obter o valor da garantia física, basta multiplicar o valor em p.u. pela potência instalada e pelo fator de capacidade máximo da UTE. Logo, confecciona-se a seguinte tabela 5.1 relacionando, a potência instalada, o custo variável, a garantia física em p.u, o fator de capacidade máxima de operação e, por fim, a garantia física em MW médios.

Tabela 5.1 - Dados para caracterização da Garantia Física

\begin{tabular}{|c|c|c|c|c|c|}
\hline $\begin{array}{c}\text { Termonorte II } \\
\text { (Combustível) }\end{array}$ & $\begin{array}{c}\text { Potência } \\
\text { Instalada } \\
\text { (MW) }\end{array}$ & $\begin{array}{c}\text { Custo } \\
\text { Variável } \\
\text { (R\$/MWh) }\end{array}$ & $\begin{array}{c}\text { Garantia } \\
\text { Física (p.u.) }\end{array}$ & FCMax & $\begin{array}{c}\text { Garantia } \\
\text { Física } \\
\text { (MWmed) }\end{array}$ \\
\hline Óleo PTE & 340 & 430,63 & 0,6086 & $90 \%$ & 186,23 \\
\hline Gás Natural & 345 & 99,51 & 1,0023 & $90 \%$ & 311,21 \\
\hline
\end{tabular}

\subsubsection{Cálculo do ICB para a Termonorte II}

A obtenção do Índice de Custo Benefício segue o rito da seção 4.4.1, com isso foi feita a análise baseando-se na Eq. 4.6 da mesma seção.

$\boldsymbol{I C B}=\underline{\text { Custos Fixos }+E(\text { Custos Variáveis })+E(\text { Custos de Curto Prazo })}$

(Eq. 5.2)

Garantia Física

Simplificando a expressão, considerando o tempo de operação de 8760 horas e já dividindo todos os termos pela garantia física, pode-se chegar à expressão final:

$$
\boldsymbol{I C B}=\boldsymbol{R} \boldsymbol{F}(R \$ / M W h)+\boldsymbol{C O P}(R \$ / M W h)+\boldsymbol{C E C}(R \$ / M W h) \quad(E q .5 .3)
$$

Os valores obtidos para o Valor Esperado do Custo Econômico de Curto Prazo (CEC) e o Valor Esperado de Custo de Operação (COP), foram fornecidos pela EPE, baseando-se na 
mesma amostra do Custo Marginal de Operação, resultando em valores médios que se encontram junto com outros na tabela 5.2 para o cálculo do ICB.

Tabela 5.2 - Dados para o cálculo do ICB

\begin{tabular}{|c|c|c|c|c|c|}
\hline $\begin{array}{l}\text { Termonorte II } \\
\text { (Combustível) }\end{array}$ & $\begin{array}{c}\text { Garantia } \\
\text { Física } \\
\text { (MWmed) }\end{array}$ & $\begin{array}{c}\text { COP } \\
(R \$ / M W h)\end{array}$ & $\begin{array}{c}\text { CEC } \\
\text { (R\$/MWh) }\end{array}$ & $\begin{array}{c}\text { Receita } \\
\text { Fixa } \\
\text { (R\$/MWh) }\end{array}$ & $\begin{array}{c}\text { ICB } \\
\text { (R\$/MWh) }\end{array}$ \\
\hline Óleo PTE & 186,23 & 24,98 & 43,11 & 115,16 & 183,25 \\
\hline Gás Natural & 311,21 & 14,95 & 25,80 & 218,64 & 259,39 \\
\hline
\end{tabular}

Nota: COP e CEC fornecidos pela EPE, respectivamente, de $R \$ 40.746 .167,75 /$ ano e de $R \$$ 70.333.591,94/ano

\subsection{Análise dos Resultados}

A comparação a ser feita com os valores de ICB calculados é baseada no 7. ${ }^{\circ}$ Leilão de Energia Nova para um ICB médio de R\$ 145,00/MWh. Logo, os valores concebidos se encontram fora do patamar aceitável do leilão, inviabilizando a situação da UTE.

O cenário com gás natural apresenta um ICB muito elevado em relação ao com óleo PTE, pode-se explicar essa situação, principalmente dentro da diferença entre a Receita Fixa para ambos combustíveis. A redução do ICB para gás natural passa por um ajuste em função do custo do gasoduto da parcela Ship or Pay (quase 56\% da Receita Fixa).

Para enquadramento e inserção no leilão, a alternativa abordada nesse estudo foi a redução da Receita Fixa, tanto para óleo PTE quanto para gás natural.

No primeiro caso, funcionamento a óleo PTE, tem-se um ICB de R \$183,25/MWh, logo ajustando-se o valor ao ICB do leilão, chega-se a uma Receita Fixa de R\$ 77,91/MWh, contabilizando numa Receita Fixa Anual de R \$ 127,10 milhões, ocasionando uma redução de $32,35 \%$ em relação ao valor original.

Para o segundo caso, geração com gás natural, tem-se um ICB de R \$ 259,39/MWh. Portanto, adequando-se ao ICB do leilão, obtém-se uma Receita Fixa de R \$ 104,25/MWh, cuja Receita Fixa Anual é de R\$ 284,21 milhões, resultando numa redução de 52,32\% do valor original.

Deve-se atentar para o fato de que a redução na Receita Fixa da Termonorte a óleo não consegue sequer remunerar o contrato com o PIE o que torna essa alternativa de difícil viabilização. Com base nisso, é mais factível uma alteração contratual quanto ao gás natural. 


\subsection{Conclusões}

O ICB é a ferramenta para definir a estratégia empresarial, alinhada ao sucesso na contratação de energia. O domínio e a interpretação do algoritmo envolvido no cálculo desse índice possibilitam ajustes em termos da Receita Fixa ou do Custo Variável.

Dentro da expansão a gás natural, a viabilidade desse caso estudado está ligada essencialmente ao abatimento da parcela Ship or Pay, ocasionando redução na parcela de transporte do gás natural. O preço máximo do gás natural deve ser analisado cuidadosamente nessa situação, pois a parcela da BR influi diretamente na venda de energia. Caso o gás natural viesse através do gasoduto Urucu-Porto Velho, o transporte ficaria muito mais barato. Uma alternativa seria uma sub-rogação à CCC - já que a interligação não ocorreu até hoje - para cobrir parte dos investimentos, visto que o uso do gás natural frente ao óleo possibilitaria uma economia muito grande, a qual iria para a própria CCC. A Conta de Consumo de Combustíveis Fósseis dos Sistemas Isolados - CCC-ISOL é administrada pela ELETROBRÁS tendo como finalidade precípua o reembolso de parte dos dispêndios com combustíveis utilizados na geração de energia elétrica nas usinas localizadas em regiões isoladas eletricamente.

O volume contratado sob a forma SoP é maior do que sob a forma ToP. Isso faz com que o ônus de assegurar o volume fornecido recaia sobre o agente que contrata a infra-estrutura para o transporte de gás natural. Já o ToP está relacionado à receita mínima para o produtor. Ambas as formas são independentes do consumo de gás natural, já que a inflexibilidade para o gás natural é muito grande, inclusive maior do que para o óleo, fazendo com que haja um consumo ininterrupto do combustível e isso representaria uma possível situação de verter água em períodos hidrologicamente favoráveis. Nota-se também que o Custo Variável do óleo é maior do que o do gás conseqüentemente a garantia física para o cenário a óleo será menor.

Portanto, o aproveitamento da usina na contratação de energia passa por uma reformulação contratual para chegar a um preço atrativo e competitivo nos leilões. 


\section{CONCLUSÕES}

Avaliar a expansão do setor elétrico é discutir as bases do vetor de desenvolvimento do país. A matriz energética brasileira apresentou uma nova temática quanto à sua evolução pela necessidade de atender demandas imediatas de crescimento e diversificação, e o que se evidenciou na contratação de energia foi a baixa participação de empreendimentos de fontes hidráulicas nos leilões de energia nova refletindo, em última instância, problemas de planejamento herdados do modelo passado, uma legislação ainda incipiente e uma falta de cultura que ainda não permitiu a constituição de um paradigma para os estudos ambientais.

A expansão da oferta de capacidade geradora não pode esperar pela superação destes problemas; a solução conjuntural e pragmática faz parte do investimento em termeletricidade, pois mesmo que representem uma diversificação e uma complementaridade ao parque energético brasileiro, as térmicas carregam o fato de uma energia não renovável e mais cara, todavia é melhor que não gerar energia e cair num colapso energético como vivido em momento anterior.

Nesses moldes que surge o gás natural como um combustível adequado às necessidades dessa expansão, pois não oferece impactos ambientais tão fortes como fontes à base de petróleo e de carvão e tem capacidade e flexibilidade de ajustar a oferta de energia elétrica à demanda crescente do país: suas instalações podem se dar próximas aos centros de carga, possibilitando geração estratégica frente às hidrelétricas e possuem menor prazo de construção.

O maior apoio que o governo pode dar ao desenvolvimento energético como um todo e, principalmente, ao gás natural é uma política clara, dando estabilidade na busca por investimentos internos e externos na ampliação desse setor.

O grande desafio do gás natural está associado a sua alta receita fixa, por causa da necessidade de cláusulas de contrato que atam os agentes envolvidos na cadeia com taxas compulsórias muito elevadas para atender à infra-estrutura de transporte e o processo de produção/exploração. Uma termelétrica à gás natural precisa gerar continuamente não podendo gerar só quando convém (nos períodos de baixa pluviosidade), pois os investimentos na estruturação dessa cadeia são muito elevados, devido à sua grande especificidade (depende da região, geralmente o combustível não pode ser aproveitado em outros empreendimentos) e a armazenagem do gás é complicada, devido a construção de reservatórios subterrâneos. Além disso, seus investimentos levam tempo para serem amortizados já que o custo de geração é dado por uma composição do custo de capital com o custo de operação. 
$\mathrm{O}$ custo da energia gerada a partir de termoelétricas à gás de grande porte pode ser reduzido por meio de mudanças regulatórias na política do gás e aplicação de subsídios nos investimentos realizados em infra-estrutura de transporte e desverticalização da cadeia produtiva da indústria do gás natural. A redução do custo posicionaria as termoelétricas como âncoras do consumo deste energético, viabilizando em longo prazo um mercado de gás secundário e ininterruptível, cujo aparecimento faz parte da estratégia de diversificação da matriz energética brasileira.

Nesse contexto, o estabelecimento de metas que reduzam o efeito da inflexibilidade associada ao gás natural é de vital importância para sua atratividade dentro da geração termelétrica, pois nosso estudo evidencia caracteres marcantes da oscilação de combustíveis ao longo dos leilões. Essa alternância é positiva pela maior variedade da matriz, mas carrega em si o fato de combustíveis agressivos ao meio ambiente e com custos elevados, colocando-se de lado os custos baixos e o grande potencial do gás natural. Torna-se, assim, crucial a estruturação de marcos confiáveis que estabeleçam um elo sólido entre a as etapas da cadeia de valor do gás natural.

Os esforços institucionais devem ser canalizados complementarmente na regulamentação do GNL e GNC, pois o gás natural é o combustível da transição de uma cultura do petróleo para outra com uso de energéticos alternativos.

Deve-se aliar a isso também ao grande potencial hidráulico que o país detém que é uma vantagem comparativa - energética e ambiental - em relação aos outros países. E novas usinas serão construídas para avançar a fronteira elétrica no Brasil, integrando novas áreas geográficas ao espaço econômico.

A abordagem nesse trabalho foi justamente de constatar e mensurar a viabilidade econômica e o cenário real da termeletricidade no Brasil, associando custos, impactos e demais parâmetros necessários para analisar a formatação do futuro da matriz energética nacional. 


\section{REFERÊNCIAS BIBLIOGRÁFICAS}

COSTA, Ricardo; PIEROBON, Ernesto. BNDES Setorial - Leilão de Energia Nova - Análise e Sistemática de Resultados, março de 2008.

MINISTÉRIO DE MINAS E DE ENERGIA, Nota Técnica: MME/CCPE-ONS. Garantia Física de Energia e Potência Metodologia, Diretrizes e Processo de Implantação, anexa à Portaria MME 303, de 18 de novembro de 2004.

EMPRESA DE PESQUISA ENERGÉTICA, Nota Técnica EPE-DEE-RE-081/2007-r2. Garantia Física dos Empreendimentos Termelétricos do Leilão de Compra de Energia Nova de A-3 e A-5 de 2007, de 26 de setembro de 2007.

EMPRESA DE PESQUISA ENERGÉTICA, Nota Técnica EPE-DEE-RE-023/2005-R2, Metodologia de Cálculo do Índice de Custo Benefício(ICB) em Termelétricas, 06 de abril de 2006.

EMPRESA DE PESQUISA ENERGÉTICA, Nota Técnica EPE-DEE-RE-116/2008-r3, Garantia Física para Usinas Termelétricas para o LEN-A3 de 2008 - Estudos da Licitação para Expansão da Geração, 26 de agosto de 2008.

INSTITUTO ACENDE BRASIL - Análise pós $4^{\circ}$ Leilão de Energia Nova, 26 de setembro de 2007. Em: <www.acendebrasil.com.br/archives/files/Analise_pos_4o_leilão_Energia_Nova.pdf >. Acesso em agosto de 2008.

INSTITUTO ACENDE BRASIL - Análise pós $5^{\circ}$ Leilão de Energia Nova, 16 de outubro de 2007. Em: <www.acendebrasil.com.br/archives/files/Analise_pos_5o_leilão_Energia_Nova.pdf >. Acesso em gosto de 2008.

INSTITUTO ACENDE BRASIL - Análise pós 6º Leilão de Energia Nova, 17 de setembro de 2008. Em: <www.acendebrasil.com.br/archives/files/Analise_pos_6o_leilão_Energia_Nova.pdf >. Acesso em setembro de 2008.

INSTITUTO ACENDE BRASIL - Análise pós $5^{\circ}$ Leilão de Energia Nova, 30 de setembro de 2008. Em: <www.acendebrasil.com.br/archives/files/Analise_pos_7o_leilão_Energia_Nova.pdf >. Acesso em setembro de 2008. 
CASTRO, Nivaldo J.; BUENO, Daniel. Os Leilões de Energia Nova: Vetores de Crise ou de Ajuste Entre Oferta e Demanda, 19 de junho de 2007.

ESPOSITO, Alexandro. Competitividade da Termoeletricidade Movida à base de Gás Natural: Estudo de Caso de um sistema predominantemente hidroelétrico - UFRJ - Tese de Mestrado, julho de 2004.

DUKE ENERGY BRASIL. Análise do $2^{\circ}$ Leilão de Energia Nova, agosto de 2006. Em: <http://www.duke-energy.com.br/Newsletter/ins04_07_pt_print.htm >. Acesso em setembro de 2008.

DUKE ENERGY BRASIL. Análise do $4^{\circ}$ Leilão de Energia Nova, agosto de 2007. Em: $<$ http://www.duke-energy.com.br/Newsletter/ins05_06_pt_print.htm >.Acesso em setembro de 2008.

MARTINS, Gilberto. Cenário da Expansão da Geração Termelétrica a partir do Gás Natural no Brasil- Universidade Metodista de Piracicaba, junho de 2001.

EMPRESA DE PESQUISA ENERGÉTICA, Informe Técnico EPE-DEE-IT-001/2007. Leilões de Compra de Energia Elétrica estabelecidos na Portaria MME 331/2007 - Cálculo do CVU para Fins da Determinação da GF, COP e CEC de Empreendimentos Termelétricos, fevereiro de 2008.

EMPRESA DE PESQUISA ENERGÉTICA, Informe Técnico EPE-DEE-IT-001/2008. Leilões de Compra de Energia Elétrica A-3 e A-5 de 2008 - Cálculo do CVU para Fins da Determinação da GF, COP e CEC de Empreendimentos Termelétricos, maio de 2008.

ELETRONORTE, Nota Técnica N. ${ }^{\circ}$ SUP1.0.D.0056.0. Contrato de Suprimento de Energia, junho de 2006.

DEMORI, Márcio Bastos. Tese de mestrado USP. GNL como mecanismo de flexibilização do suprimento de gás natural para geração termelétrica no Brasil. São Paulo, 2008.

O SITE DO GÁS NATURAL - GNV. Em: < http://www.gasnet.com.br/>. Acesso em setembro de 2008.

INSTITUTO DE DESENVOLVIMENTO ESTRATÉGICODO SETOR ENERGÉTICO. Em: < http://www.ilumina.org.br/zpublisher/secoes/home.asp >. Acesso em setembro de 2008. 
CÂMARA DE COMERCIALIZAÇÃO DE ENRGIA ELÉTRICA. Em: < http://www.ccee.org.br/cceeinterdsm/v/index.jsp?

vgnextoid=2e09a5c1de88a010VgnVCM100000aa01a8c0RCRD>. Acesso em agosto de 2008.

AGÊNCIA NACIONAL DE ENERGIA ELÉTRICA - ANEEL. Em: < http://www.aneel.gov.br/>. Acesso em setembro de 2008.

AGÊNCIA NACIONAL DO PETRÓLEO, GÁS NATURAL E BIOCOMBUSTÍVEIS - ANP. Boletim mensal do gás natural, referência: junho de 2008. Em: < http://www.anp.gov.br/ >. Acesso em setembro de 2008.

EMPRESA DE PESQUISA ENERGÉTICA, Plano Decenal de Expansão de Energia 2007/2016. Em: < http://www.epe.gov.br/default.aspx >. Acesso em agosto de 2008.

ELETRONORTE, Nota Técnica EPEE - 03/2007. Atratividade Econômica das UTE Termonorte I e II após a Interligação do Sistema Acre-Rondônia ao SIN da Gerência de Planejamento Energético, fevereiro de 2007.

SHAYANI, Rafael Amaral. Trabalho de Graduação em Engenharia Elétrica - USP. Análise Comparativa da Geração Elétrica Hídrica vs Gás Natural. São Paulo, 1998.

ENERGY INFORMATION ADMINISTRATION - Department of Energy (EIA/DOE). "International Energy Outlook". EIA/DOE, 2005a. Em: < http://www.eia.doe.gov/fuelcoal.html >. Acesso em agosto de 2008.

COUNTRY WATCH FORECAST. Energy forecast. Em: < http://forecast.countrywatch.com/energy/default.aspx >. Acesso em agosto de 2008.

BP. Statistical Review of World Energy June 2008. Em: < http://www.bp.com/productlanding.do? categoryId=6929\&contentId $=7044622>$. Acesso em julho de 2008. 